\begin{tabular}{l} 
2. To: (Receiving Organization) \\
Spent Nuclear Fue1 \\
\hline 5. Proj./Prog./Dept./Div.: \\
SNF
\end{tabular}

3. From: (Originating Organization)
NHC/Modeling Engrg Anlays is
$\begin{aligned} & \text { 6. Design Authority/Design Agent/Cog. Engr.: } \\ & \text { F. J. Hea rd }\end{aligned}$

8. Originator Remarks:

Transmittal of HNF-4109, Rev. 0 "Thermal Assessment of shippingport Pressurized Water Reactor Blanket Fuel Assemblies Within a Multi-Canister Overpack within the Canister Storage Building"

11. Receiver Remarks: 11A. Design Baseline Document? $\bigcirc$ Yes $\bigcirc$ No

4 Related EDT No:

$\mathrm{N} / \mathrm{A}$

7. Purchase Order No::

$\mathrm{N} / \mathrm{A}$

9. Equip./Component No.:

$\mathrm{N} / \mathrm{A}$

10. System/8idg./Facility:

N/A

12. Major Assm. Dwg. No.:

N/A

13. Permit/Permit Application No.:

$\mathrm{N} / \mathrm{A}$

14. Required Response Date:

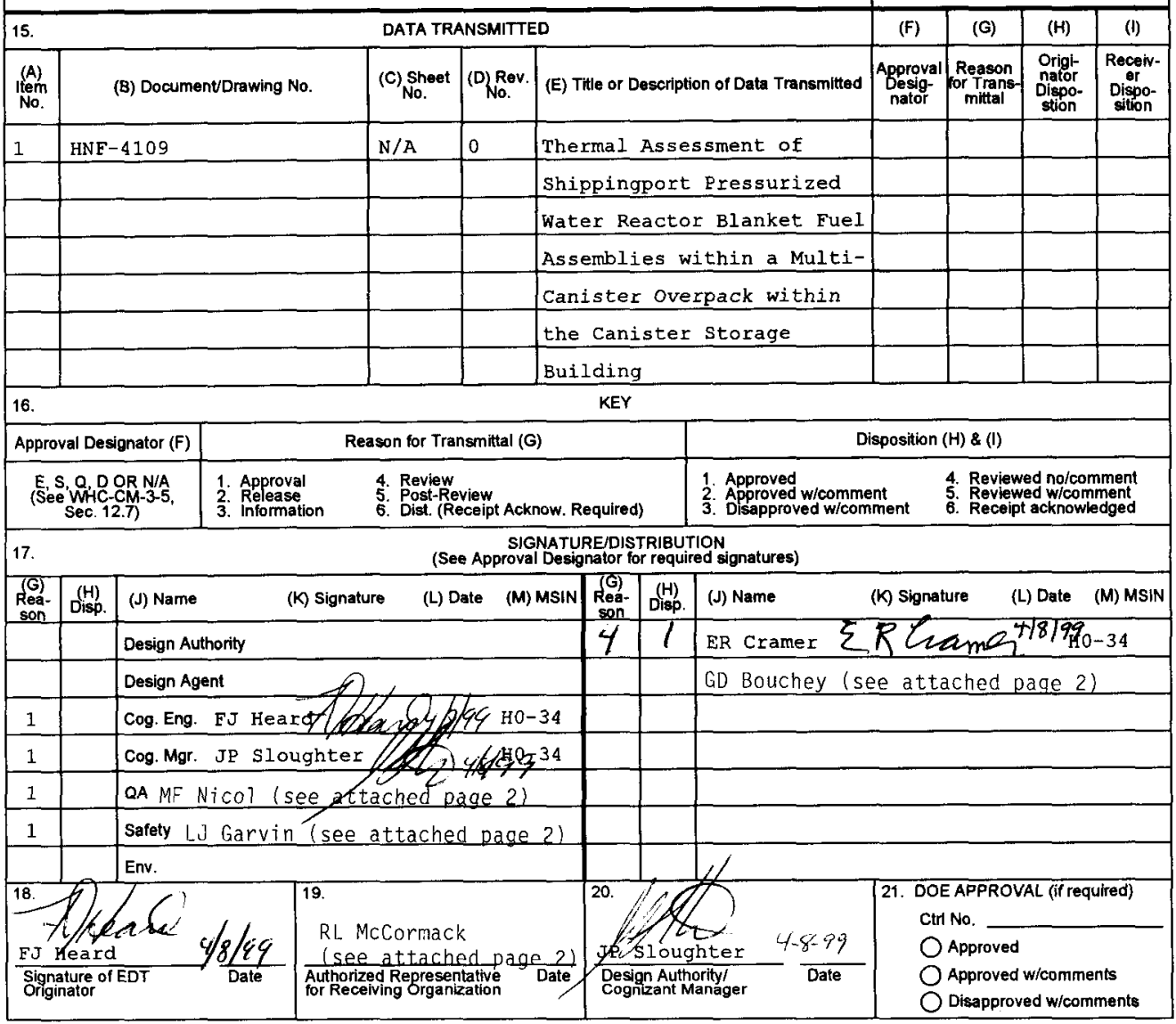


EDT - 626227

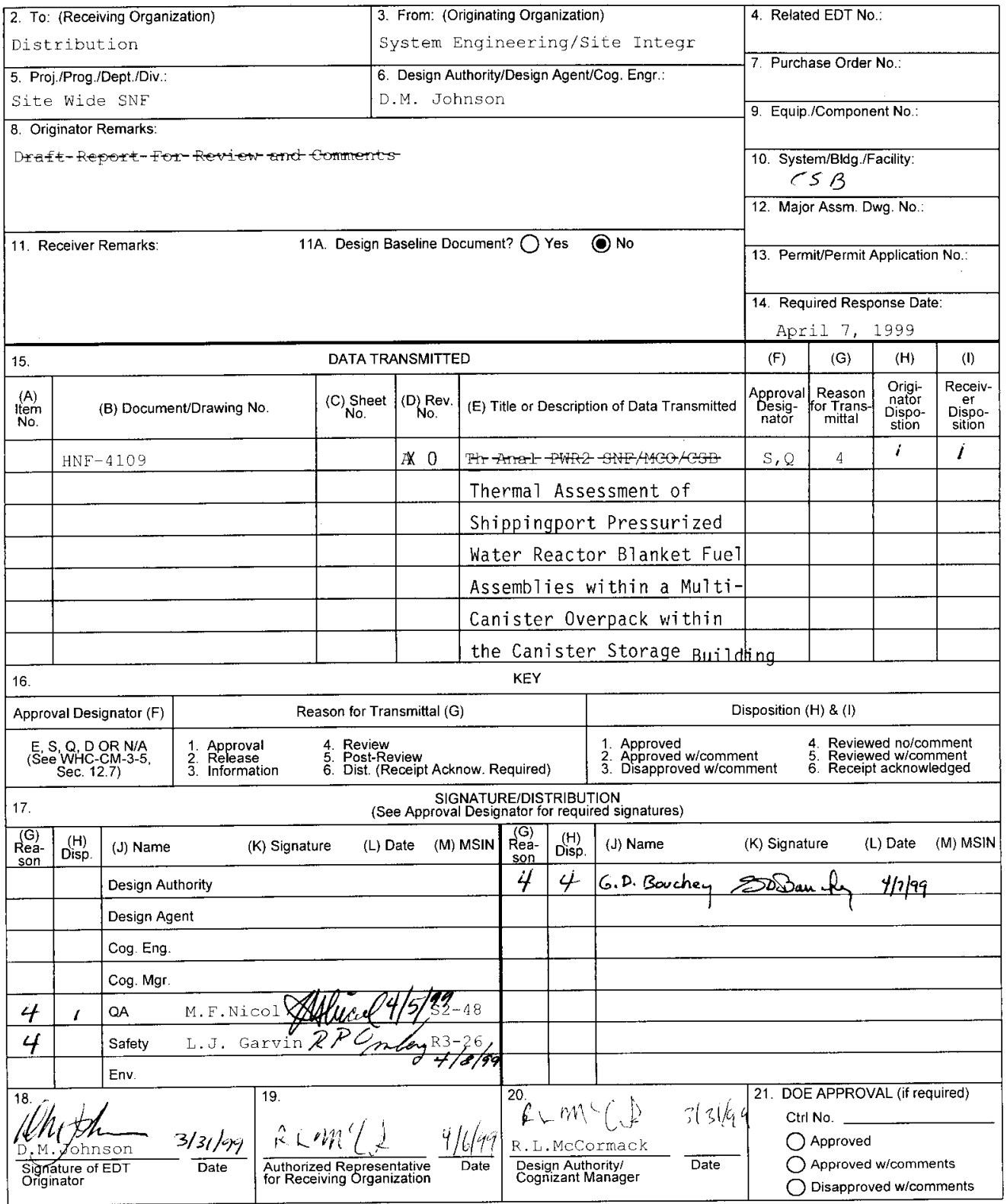




\title{
THERMAL ASSESSMENT OF SHIPPINGPORT PRESSURIZED WATER REACTOR BLANKET FUEL ASSEMBLIES WITHIN A MULTI-CANISTER OVERPACK WITHIN THE CANISTER STORAGE BUILDING
}

\author{
F. J, Heard \\ Numatec Hanford Corporation \\ Richland, WA 99352 \\ U.S. Department of Energy Contract DE-AC06-96RL13200 \\ EDT/ECN: 626227 \\ UC: 2020 \\ Org Code: 82600 \\ Charge Code: 105667 \\ B\&R Code: EW3120072

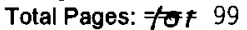

$$
k_{N}
$$

Key Words: thermal analysis, peak cladding surface temperature, blanket fuel assembly, shippingport, multi-canister overpack, canister storage building.

Abstract: A series of analyses were performed to assess the thermal performance characteristics of the Shippingport Pressurized Water Reactor Core 2 Blanket Fuel Assemblies as loaded within a Multi-Canister Overpack within the Canister Storage Building. A two-dimensional finite element was developed, with enough detail to model the individual fuel plates: including the fuel wafers, cladding, and flow channels.

TRADEMARK DISCLAIMER. Reference herein to any specific commercial product, process, or service by trade name trademark, manufacturer, or otherwise, does not necessarily constitute or imply its endorsement, recommendation, or favoring by the United States Government or any agency thereof or its contraclors or subcontractors.

Printed in the United States of America. To obtain copies of this document, contact: Document Control Services, P.O. Box 950, Mailstop H6-08, Richland WA 99352, Phone (509) 372-2420; Fax (509) 376-4989.
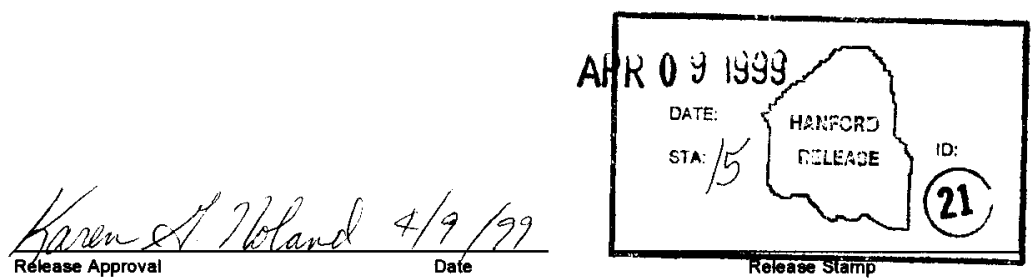


\title{
HNF-4109, Rev. 0
}

\section{THERMAL ASSESSMENT OF SHIPPINGPORT PRESSURIZED WATER REACTOR BLANKET FUEL ASSEMBLIES WITHIN A MULTI-CANISTER OVERPACK WITHIN THE CANISTER STORAGE BUILDING}

\author{
Prepared by:
}

\author{
F. J. Heard
}

Numatec Hanford Corporation

April 1999 
HNF-4109, Rev.0

\section{ABSTRACT}

A series of analyses were performed to assess the thermal performance characteristics of the Shippingport Pressurized Water Reactor (PWR) Core 2 Blanket Fuel Assemblies (BFA) as loaded within a MultiCanister Overpack (MCO) within the Canister Storage Building (CSB). A two-dimensional finite element model was developed, with enough detail to model the individual fuel plates: including the fuel wafers, cladding, and flow channels. The goal of these analyses was to determine the peak cladding surface temperature for a range of decay heats and ambient temperatures. The analysis methods and modeling assumptions are discussed and the results of the analyses are presented. 


\section{TABLE OF CONTENTS}

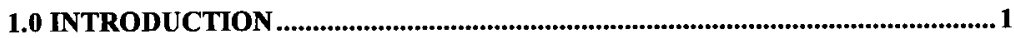

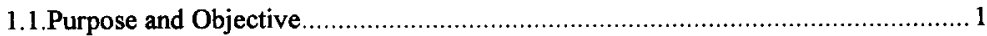

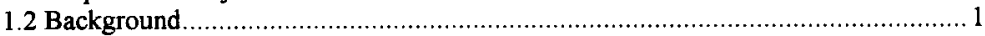

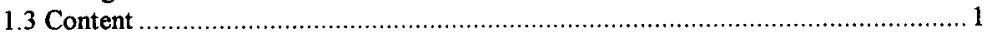

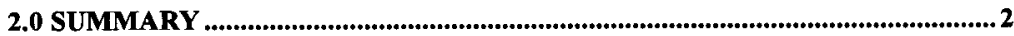

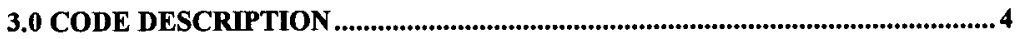

4.0 MODEL DEVELOPMENT, ANALYSIS METHODOLOGY, AND

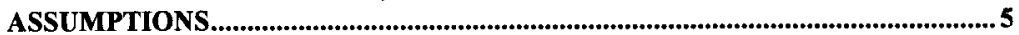

4.1 Description of Multi-canister Overpack, Canister Storage Building, and Blanket Fuel Assembly ................................................................................... 5

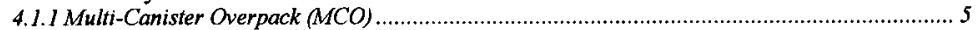

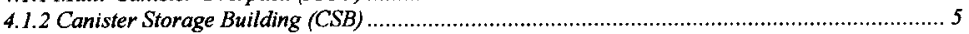

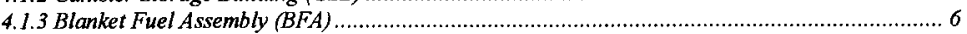

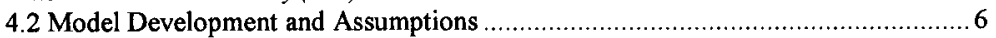

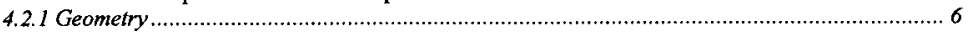

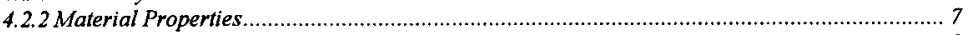

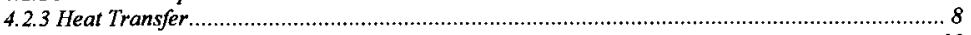

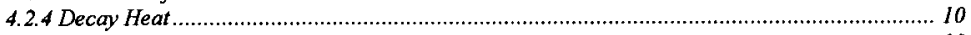

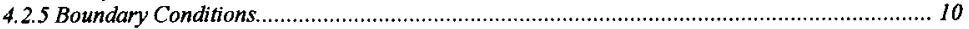

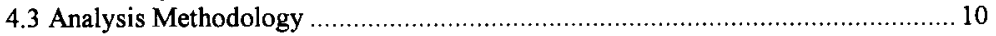

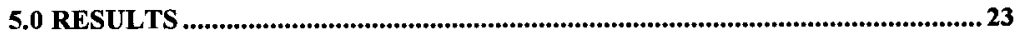

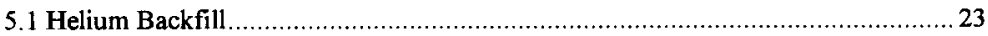

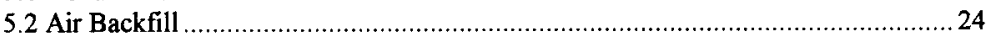

5.3 Comparison of Hand Calculations with Simulation Results .......................... 26

6.0 CONCLUSIONS AND RECOMMENDATIONS..........................................40

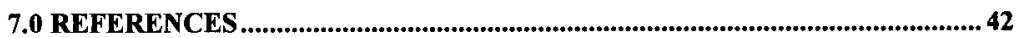

APPENDIX A 
HNF-4109, Rev.0

\section{LIST OF TABLES}

4-1 Non-Isotropic Thermal Conductivity Multipliers............. 12

4-2 Volumetric Heat Generation Rates for the Thermal Analysis of the Shippingport Blanket fuel Assemblies........................13

4-3 Heat Transfer Coefficients for a Vertical Cylinder for Various Wall Temperatures Given Two Constant Ambient Conditions...14

5-1 Peak Cladding Temperatures for the Shippingport Blanket Fuel Assemblies At Steady-State Conditions Within a Multi-Canister Overpack Within the Canister Storage Building.

5-2 Comparison of Hand Calculations With Base Case Simulation Results for Helium and Dry Air Backfill (Decay Heat $=164.7$ Watts, $\left.\mathrm{P} / \mathrm{A}=1.00, \mathrm{~T}_{\mathrm{amb}}=140^{\circ} \mathrm{F}\left(333.2^{\circ} \mathrm{K}\right)\right) \ldots \ldots \ldots \ldots \ldots \ldots .28$ 
HNF-4109, Rev.0

\section{LIST OF FIGURES}

4-1 Plan and Sections Views of a MCO Containing Four Shippingport Blanket Fuel Assemblies..................................15

4-2 Isometric View of Shippingport Blanket Fuel Assembly........16

4-3 Blanket Fuel Assembly Cluster Details.......................17

4-4 Blanket Fuel Plate ........................................ 18

4-5 Outline of Major Components within Thermal Model ...........19

4-6 Detailed Outline of Blanket Fuel Assembly ...................20

4-7 Blanket Fuel Sub-Assembly Mesh Without Fuel Wafers.........21

4-8 Blanket Fuel Sub-Assembly Mesh for Fuel Wafers Only .........22

5-1 Temperature Contour Plot for Helium Backfill - Maximum Conditions (Decay Heat $=164.7$ Watts, $\mathrm{P} / \mathrm{A}=1.55, \mathrm{~T}_{\mathrm{amb}}=140^{\circ} \mathrm{F}$ $\left.\left(333.2^{\circ} \mathrm{K}\right)\right)$.

5-2 Temperature Contour Plot for Helium Backfill - Minimum Conditions (Decay Heat $=93.39$ Watts, $\mathrm{P} / \mathrm{A}=1.55, \mathrm{~T}_{\mathrm{amb}}=110^{\circ} \mathrm{F}$ $\left.\left(316.5^{\circ} \mathrm{K}\right)\right)$

5-3 Temperature Contour Plot for Helium Backfill - Base Case Conditions (Decay Heat $=164.7$ Watts, $\mathrm{P} / \mathrm{A}=1.00, \mathrm{~T}_{\mathrm{amb}}=140^{\circ} \mathrm{F}$ $\left(333.2^{\circ} \mathrm{K}\right)$ )

5-4 Temperature Contour Plot for Helium Backfill - Base Case Conditions Near Center of MCO (Decay Heat $=164.7$ Watts, P/A

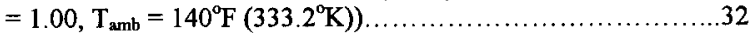

5-5 Coordinate Direction for Line Plots.........................33

5-6 Temperature versus Horizontal Distance for Helium Backfill Base Case BFA Thermal Model - Including Peak Temperature (Decay Heat $=164.7$ Watts, $\left.\mathrm{P} / \mathrm{A}=1.00, \mathrm{~T}_{\mathrm{amb}}=140^{\circ} \mathrm{F}\left(333.2^{\circ} \mathrm{K}\right)\right) \ldots \ldots .34$

5-7 Temperature versus Vertical Distance for Helium Backfill Base Case BFA Thermal Model - Including Peak Temperature (Decay Heat $=164.7$ Watts, $\left.\mathrm{P} / \mathrm{A}=1.00, \mathrm{~T}_{\mathrm{amb}}=140^{\circ} \mathrm{F}\left(333.2^{\circ} \mathrm{K}\right)\right) \ldots \ldots .35$ 
5-8 Temperature Contour Plot for Dry Air Backfill - Maximum Conditions (Decay Heat $=164.7$ Watts, $\mathrm{P} / \mathrm{A}=1.55, \mathrm{~T}_{\text {amb }}=140^{\circ} \mathrm{F}$ $\left(333.2^{\circ} \mathrm{K}\right)$

5-9 Temperature Contour Plot for Dry Air Backfill - Minimum Conditions (Decay Heat $=93.39$ Watts, $\mathrm{P} / \mathrm{A}=1.55, \mathrm{~T}_{\mathrm{amb}}=110^{\circ} \mathrm{F}$ $\left.\left(316.5^{\circ} \mathrm{K}\right)\right)$

5-10 Temperature Contour Plot for Dry Air Backfill - Base Case Conditions $\left(\right.$ Decay Heat $=164.7$ Watts, $P / A=1.00, T_{\text {amb }}=140^{\circ} \mathrm{F}$ $\left.\left(333.2^{\circ} \mathrm{K}\right)\right)$ 38

5-11 Temperature Contour Plot for Dry Air Backfill - Base Case Conditions Near Center of MCO (Decay Heat $=164.7$ Watts, P/A $\left.=1.00, \mathrm{~T}_{\mathrm{amb}}=140^{\circ} \mathrm{F}\left(333.2^{\circ} \mathrm{K}\right)\right)$ 
HNF-4109, Rev.0

Nomenclature (SI and English Units)

\begin{tabular}{|c|c|c|}
\hline Wuaniny & SII & Engilsh \\
\hline Length (L) & meter $(\mathrm{m})$ & Inches (in.) or feet (ft) \\
\hline Time (t) & second $(s)$ & Second $(\mathrm{s})$ or hour $(\mathrm{hr})$ \\
\hline Mass (m) & Kilogram (Kg) & Pound (lbm) \\
\hline Temperature (T) & Kelvin $\left({ }^{\circ} \mathrm{K}\right)$ & Fahrenheit $\left({ }^{\circ} \mathrm{F}\right)$ or Rankin $\left({ }^{\circ} \mathrm{R}\right)$ \\
\hline Force (F) & Newton $(\mathrm{N})$ & Pound (lbf) \\
\hline Energy & Joule $(\mathrm{J})$ or $(\mathrm{N}-\mathrm{m})$ & Btu \\
\hline Gravitational Acceleration (g) & $9.8066 \mathrm{~m} / \mathrm{s}^{2}$ & $32.1739 \mathrm{ft} / \mathrm{s}^{2}$ \\
\hline Density $(\rho)$ & $\mathrm{Kg} / \mathrm{m}^{3}$ & $\mathrm{lbm} / \mathrm{ft}^{3}$ \\
\hline Velocity (v) & $\mathrm{m} / \mathrm{s}$ & $\mathrm{ft} / \mathrm{s}$ \\
\hline Pressure (P) & Pascal $\left(\mathrm{N} / \mathrm{m}^{2}\right)$ & $\mathrm{lbf} / \mathrm{in}^{2}$ \\
\hline Dynamic Viscosity $(\mu)$ & Pascal-s $(\mathrm{Kg} / \mathrm{m}-\mathrm{s})$ & $1 \mathrm{bm} / \mathrm{ft}-\mathrm{s}$ \\
\hline Kinematic Viscosity (v) & $\mathrm{m}^{2} / \mathrm{s}$ & $\mathrm{ft}^{2} / \mathrm{s}$ \\
\hline Specific Heat (Cp) & $\mathrm{J} / \mathrm{Kg}-{ }^{\circ} \mathrm{K}$ & $\mathrm{Btu} / \mathrm{lbm}-{ }^{\circ} \mathrm{F}$ \\
\hline Power (Q) & Watt $(\mathrm{W})$ or $(\mathrm{J} / \mathrm{s})$ & Btu/hr \\
\hline Heat Flux & $\mathrm{J} / \mathrm{m}^{2}-\mathrm{s}$ & $\mathrm{Btu} / \mathrm{ft}^{2}-\mathrm{hr}$ \\
\hline Volumetric Heat Source & $\mathrm{J} / \mathrm{m}^{3}-\mathrm{s}$ & Btu/ft ${ }^{3}-\mathrm{hr}$ \\
\hline Heat Transfer Coefficient $\left(\mathrm{h}_{\mathfrak{c}}\right)$ & $\mathrm{J} / \mathrm{m}^{2}-\mathrm{s}-{ }^{0} \mathrm{~K}$ & $\mathrm{Btu} / \mathrm{ft}^{2}-\mathrm{hr}-{ }^{\circ} \mathrm{F}$ \\
\hline Thermal Conductivity (k) & $\mathrm{J} / \mathrm{m}-\mathrm{s}^{\circ} \mathrm{K}$ & Btu/ft-hr- ${ }^{\circ} \mathrm{F}$ \\
\hline Thermal Diffusivity $(\alpha)$ & $\mathrm{m}^{2} / \mathrm{s}$ & $\mathrm{ft}^{2} / \mathrm{s}$ \\
\hline Mass Diffusivity & $\mathrm{m}^{2} / \mathrm{s}$ & $\mathrm{ft}^{2} / \mathrm{s}$ \\
\hline Volume Expansion Coefficient $(\beta)$ & $1 / \% \mathrm{~K}$ & $1 / \% \mathrm{R}$ \\
\hline Surface Reaction Rate (mass units) & $\mathrm{Kg} / \mathrm{m}^{2}-\mathrm{s}$ & $\mathrm{lbm} / \mathrm{ft}^{2}-\mathrm{s}$ \\
\hline Volumetric Reaction Rate (mass units) & $\mathrm{Kg} / \mathrm{m}^{3}-\mathrm{s}$ & $\mathrm{lbm} / \mathrm{ft}^{3}-\mathrm{s}$ \\
\hline Heat of Reaction (mass units) & $\mathrm{J} / \mathrm{Kg}$ & $\mathrm{Btu} / \mathrm{lbm}$ \\
\hline Gravitational Constant $\left(\mathrm{gc}_{\mathrm{c}}\right)$ & $1 \mathrm{Kg}-\mathrm{m} / \mathrm{N}-\mathrm{s}^{2}$ & $32.174 \mathrm{lbm}-\mathrm{ft} / \mathrm{lbf}-\mathrm{s}^{2}$ \\
\hline Stefan-Boltzman Constant ( $\sigma)$ & $5.6697 \mathrm{E}-8 \mathrm{~J} / \mathrm{s}-\mathrm{m}^{2}-{ }^{0} \mathrm{~K}^{4}$ & $1.714 \mathrm{E}-9 \mathrm{Btu} / \mathrm{hr}-\mathrm{ft}^{2}-{ }^{\circ} \mathrm{R}^{4}$ \\
\hline Universal Gas Constant $\left(\mathrm{R}_{\mathrm{u}}\right)$ & $8314.34 \mathrm{~J} / \mathrm{Kgmole}-{ }^{\circ} \mathrm{K}$ & $1545 \mathrm{ft}-\mathrm{lbm} / \mathrm{lbm}-\mathrm{mole}-{ }^{\circ} \mathrm{F}$ \\
\hline
\end{tabular}




\subsection{INTRODUCTION}

\subsection{Purpose and Objective}

The purpose of this report is to document the results of a series of analyses that were performed to assess the thermal performance of the Shippingport Pressurized Water Reactor (PWR) Core 2 Blanket Fuel Assemblies (BFA) within Multi-Canister Overpacks (MCOs) within the Canister Storage Building (CSB). Specifically, the goal of these analyses was to determine the peak cladding surface temperature for a range of decay heats and ambient temperatures. The results of these analyses are expected to provide general guidance on the acceptability of using a MCO and the CSB to store the subject blanket fuel assemblies.

The primary objectives of this analysis effort were: 1) develop the necessary thermal models with enough detail to allow the individual fuel plates and, hence, cladding thickness to be modeled, and 2) support the definitive design recommendations for the long term storage of the Shippingport blanket fuel assemblies within the CSB.

\subsection{Background}

Seventy-two Shippingport PWR Core 2 spent BFAs are currently stored within the TPlant at the Hanford site. A recommendation (Carlson 1996) has been made to transfer the BFAs from the T Plant to the CSB for vault storage. It is expected that nine CSB storage tubes will be required: given four BFAs per MCO and two MCOs per CSB storage tube.

The Blanket Fuel Assemblies were irradiated at the Shippingport pressurized water reactor located near Pittsburgh, Pennsylvania in the late 1960's through early 1970's. The decay heat of the individual assemblies has decreased significantly during the past 25 to 30 years.

\subsection{Content}

Section 2.0 provides a brief summary of the analysis results and conclusions. Section 3.0 discusses the computer program that was used to perform the analyses. Section 4.0 discusses the model development and assumptions that were made for the analyses. Section 5.0 presents the result of the analyses. Section 6.0 summarizes the results and conclusions. Section 7.0 provides the references. 


\subsection{SUMMARY}

Given one-fourth symmetry, a two-dimensional finite-element thermal model was developed of a MCO containing four Shippingport Blanket Fuel Assemblies within a storage tube at the CSB. The thermal model contained enough detail to model the individual fuel plates; including each of the individual fuel wafers, cladding, and flow channels. The thermal model also modeled the surrounding blanket fuel sub-assembly cans, MCO, and CSB storage tube.

The goal of the thermal analyses was to determine the peak cladding surface temperature for a range of decay heats and ambient vault conditions during nominal steady-state operations. The results of these analyses are expected to provide general guidance and support for the recommendation to transfer the spent Shippingport BFAs to the CSB.

The total assembly decay heat from a maximum exposure assembly was 164.70 Watts. Peak-to-average (P/A) axial multipliers of 1.00 and 1.55 were used to derive the corresponding volumetric heat generation rate for input to the thermal model. (The peakto-average multiplier of 1.55 is based on a representative cosine shape for the axial power distribution.) The peak ambient air temperature within the CSB vault ranged from $110^{\circ} \mathrm{F}$ $\left(316.48^{\circ} \mathrm{K}\right)$ to $140^{\circ} \mathrm{F}\left(333.15^{\circ} \mathrm{K}\right)$.

In each case, an energy balance was performed to confirm that the energy produced and removed from the energy model was in agreement with the values summarized in Table 4-2.

Seven conclusions are made and a single recommendation is offered in the last paragraph.

The conclusions are as follows:

1.) The maximum peak cladding temperature is $410.5^{\circ} \mathrm{F}\left(483.4^{\circ} \mathrm{K}\right)$, given maximum (X 1.55) decay heat, maximum CSB outlet temperature, and dry air (not helium) filled MCO and CSB storage tube.

2.) The corresponding maximum (X 1.55) peak cladding temperature for a helium filled MCO and CSB storage tube is $335.9^{\circ} \mathrm{F}\left(442.0^{\circ} \mathrm{K}\right)$.

3.) For minimum decay heat and CSB outlet temperature the peak cladding temperatures range from $197.9^{\circ} \mathrm{F}\left(365.3^{\circ} \mathrm{K}\right)$ to $247.1^{\circ} \mathrm{F}\left(392.6^{\circ} \mathrm{K}\right)$ for a helium and dry air filled MCO and CSB storage tube, respectively.

4.) Most of the temperature rise occurs over the large gaps between the $\mathrm{MCO}$ and CSB storage tube and the MCO and blanket fuel assembly.

5.) Very little temperature rise occurs within the blanket fuel assembly. 
6.) Very good agreement was obtained between the results of the numerical simulations and a series of hand calculations. The greatest difference occurred when trying to estimate the temperature rise across the wedge shaped gap between the perimeter of the BFA and the ID of the MCO. Based on the agreement between the results of the hand calculations and the numerical simulation, the BFA thermal model was properly developed. Since each case is identical except for input differences associated with the decay heat, backfill gas, and ambient temperature, the results presented in this report are considered reasonable and representative for the given assumptions and conditions.

7.) The two-dimensional Blanket Fuel Assembly thermal model is considered conservative. Some conservatism's are; no external radiation losses, no internal convective heat transport, and the simultaneous application of worst case conditions to a single storage tube. An additional conservatism, which continues to increase, is; the actual decay time after shutdown is greater than the 24 years assumed when deriving the total assembly decay heat.

8.) Uncertainties in the decay heat loads, geometry, and ambient storage vault conditions will affect peak cladding temperature. Because most of the temperature rise occurs over the various gaps, it is expected that the geometrical position of the blanket fuel assembly within the MCO will have the greatest affect on peak cladding temperatures.

The following recommendation is offered:

Given the dimension of the MCO, the blanket fuel assemblies can rotate and/or tilt axially during transportation and handling. It is recommended that the spacer basket be modified to add small (two or three inches) projecting brackets just beyond the edge of each blanket assembly. These small brackets will help position the blanket fuel assemblies within the MCO canister consistent with the thermal analyses. 


\subsection{CODE DESCRIPTION}

The Fluid Dynamic Analysis Package (FIDAP) computer program was used to perform the thermal analyses of the Shippingport Blanket Fuel Assemblies. FIDAP has been validated and verified for use at Hanford (Heard 1994) for the performance of quality affecting analyses.

FIDAP is a commercially available general purpose computer package that uses finite element methods (FEM) to simulate many classes of single or multi-phase compressible or incompressible flows, including heat transfer, and mass transport of chemical species $(<15)$ in both nonreacting and reacting flows. The simulation can be either steady-state or transient and can model flows in complex arbitrary geometries that are 2-D, axisymmetric, or 3-D. Mixed coordinate, moving, and rotating systems are supported.

FIDAP can be thought of as a single environment for the simulation of thermal-hydraulic problems and can be viewed as an integrated set of components and program modules designed to perform all aspects of model generation, automatic meshing, or paving, problem setup including view factor calculations, solving the resulting matrix of simultaneous finite element forms of the equations for the conservation of momentum, mass, and energy, and post-processing (i.e., visualizing) the results. Users can complete control over each of the conservation equations. For example, only the energy equation would be activated for a thermal analysis. For a coupled thermal-hydraulic analysis, both the conservation of energy and momentum equations can be activated. For a thermalhydraulic analysis with reacting flows the conservation of energy, momentum, and mass equations would be activated. The post- processing capabilities of FIDAP are considered one of the industries best.

FIDAP is currently active on a Silicon Graphics Power Indigo-2, with an R-10000 CPU, $256 \mathrm{Mb}$ of main system memory, running under the IRIX 6.2 operating system with FORTRAN 77 Version 7.0. The IRIX 6.2 operating system uses a 64-bit single precision word length for real and integer values.

ॠFIDAP is a registered trademark of Fluid Dynamics, Inc., Evanston, Illinois. 
HNF-4109, Rev.0

\subsection{MODEL DEVELOPMENT, ANALYSIS METHODOLOGY, AND ASSUMPTIONS}

A single thermal model was developed for the analysis of the Shippingport PWR Core 2 Blanket Fuel Assemblies within a MCO within a CSB storage tube. The thermal model was detailed enough to model the individual fuel plates; including the individual fuel wafers, cladding and flow channels within the blanket assemblies.

4.1 Description of Multi-canister Overpack, Canister Storage Building, and Blanket Fuel Assembly

Figure 4-1 presents a plan and section view of a MCO containing four Shippingport blanket fuel assemblies. Figures 4-2 through 4-4 present dimensional details associated with the Blanket Fuel Assembly and its components.

\subsubsection{Multi-Canister Overpack (MCO)}

The MCO will contain spent nuclear fuel in a variety of forms ranging from the highly corroded K-basin spent fuel elements to nearly pristine but irradiated light water reactor fuel assemblies.

A MCO is essentially a large diameter pipe loaded with spent nuclear fuel and sealed at both ends. For the majority of the K-Basin fuel, the MCO is expected to be vacuum processed at the Cold Vacuum Drying Facility (CVDF) to remove water moisture and back-filled with helium. It is not known if the same vacuum drying process will be used or is even necessary for the Shippingport blanket fuel assemblies. The upper end plug is massive enough to act as a radiation shield for manual operations requiring personnel access. The MCO has an outer diameter of 23.985 inches $(0.609219 \mathrm{~m})$, a wall thickness of 0.5 inches $(0.0127 \mathrm{~m})$, and an inner diameter of 22.985 inches $(0.583819 \mathrm{~m})$. The MCO is fabricated from stainless steel 304. The MCO is described in Lorenz (1997) in much greater detail.

The inner diameter of the MCO is such that four Shippingport blanket fuel assemblies can be loaded. A spacer basket or cruciform insert will be used to subdivide the interior of the MCO into four quadrants; hence, one-fourth symmetry. Each quadrant will contain a blanket fuel assembly.

\subsubsection{Canister Storage Building (CSB)}

The Canister storage Building provides a dry environment for the storage of spent nuclear fuel away from the Columbia River. The Canister Storage Building contains three underground vaults and above ground operating and miscellaneous support areas.

A CSB storage tube has an outer diameter 28 inches and an inner diameter of 27 inches. A diametrical gap of approximately 1.5 inches will occur between the outer diameter of the MCO and inner diameter of the CSB storage tube. Vault number one contains 220 
vertical storage tubes. Each of the CSB storage tubes can contain two MCOs stacked on top of each other for $440 \mathrm{MCO}$. The CSB is designed for a decay heat load of approximately $192 \mathrm{~kW}$.

The Canister Storage Building is designed to be cooled by natural circulation driven by the density difference between the vault inlet and outlet air. With a fully loaded CSB vault, the long-term concrete temperature will be maintained below $150^{\circ} \mathrm{F}\left(339.7^{\circ} \mathrm{K}\right)$. The maximum outlet air temperature is estimated to be approximately $140^{\circ} \mathrm{F}\left(333.2^{\circ} \mathrm{K}\right)$ given a maximum inlet temperature of $110^{\circ} \mathrm{F}\left(316.5^{\circ} \mathrm{K}\right)$.

\subsubsection{Blanket Fuel Assembly (BFA)}

Each blanket fuel assembly, as shown in Figure 4-3, consists of two sub-assemblies (half an assembly) separated by a small gap. Each half consists of 30 fuel plates, as shown in Figure 4-4, arranged within a rectangular can with 31 flow channels. Each fuel plate is 0.140 inches thick. Each fuel plate consists of high density (> 96\% TD) natural uranium oxide fuel wafers 0.100 inches thick by approximately 0.250 inches wide clad on both sides with Zircaloy-4 0.020 inches thick. Each fuel plate contains 10 fuel wafers. The overall fueled length is 96.5625 inches $(2.4527 \mathrm{~m})$. The fuel plate cladding also contains transverse and longitudinal ribbing between each of the fuel wafers. The center or interior flow channels are 0.091 inches thick and the two end channels are 0.066 inches thick.

\subsection{Model Development and Assumptions}

Figures 4-5 through 4-8 illustrate the two-dimensional finite element model that was developed to perform the thermal analyses. Figures 4-5 through 4-8 was obtained using a screen print option within the FIDAP computer code.

The goal of these analyses was to determine the peak cladding surface temperature. The thermal model was developed with enough detail to identify each of the individual fuel wafers, cladding, and flow channels within each subassembly. This was necessary to resolve the energy transport within each subassembly, since the thermal resistance is significantly less along each fuel plate than across each flow channel.

\subsubsection{Geometry}

As discussed in section 4.1, the thermal model represents a single Shippingport blanket fuel assembly within a MCO within a CSB storage tube. The dimensions of the MCO and CSB storage tube are well known and can be modeled exactly. However, the location of the blanket fuel assembly within the MCO is not that precise. The blanket fuel assembly could be positioned tightly against the center insert resulting in maximum separation distance from the $\mathrm{MCO}$. In addition, given the dimensions of the $\mathrm{MCO}$, the blanket fuel assemblies can rotate and/or tilt axially during transportation and handling. It must be noted that the subject analyses did not treat the position of the blanket fuel 
assembly within the $\mathrm{MCO}$ as a variable. Each different location for a blanket fuel assembly would require a new model with different meshing to accommodate the changes in the separation distances, as well as a recalculation of the radiation view factors between the various surfaces.

Figure 4-5 presents the major components that comprise the Shippingport BFA thermal model. The spacer basket is shown as the "L" shaped right angle item in the center of the model. The blanket fuel assembly is fixed 0.25 inches from the spacer basket. This thermally isolates the blanket fuel assembly from the spacer basket, which acts as a large fin conducting energy away from the interior of the MCO. The two sub-assembly cans surrounding the fuel plates are clearly shown. The small gap ( 0.0855 inches $)$ between each subassembly is also shown. The outermost corner of the BFA is approximately 0.34 inches from the MCO inner diameter.

Figure 4-6 presents the details associated with the fuel plates within each sub-assembly. The 31 flow channels, 30 fuel plates, and 300 fuel wafers within each sub-assembly are clearly shown. The fuel plates are shown contacting the surrounding sub-assembly can.

Figure 4-7 presents the meshing associated with one BFA sub-assembly. The fuel wafer meshing is not shown in order to allow a better visualization of the meshing associated with the surrounding can, fuel plate cladding, and flow channels. The clad ribbing between each of the fuel wafers is clearly shown. Figure 4-8 presents the fuel wafer meshing. Visually the elements within Figure 4-7 and 4-8 may appear slightly distorted, but they are not. Figures 4-5 through 4-8 were obtained using a screen print option and reflect the resolution of the video monitor.

The interior of the blanket fuel assembly was modeled using 151 elements over 6.971 inches in the $\mathrm{X}$ directions and 65 elements over 3.25 inches in the $\mathrm{Y}$ direction. The 151 elements can be factored into 60 elements for the fuel wafers, 60 elements for the cladding faces, 2 elements for the end channels, and 29 elements for the internal flow channels. The resulting size of an element in the $\mathrm{X}$ direction is 0.046166 inches and does not accurately represent the true thickness of the individual flow channels, cladding and fuel wafers and required the use of non-isotropic thermal conductivity (see Section 4.2.2). The resulting size of an element in the $Y$ direction is 0.050 inches and does allow an accurate representation of each fuel plate, clad ribbing, and the individual fuel wafers

\subsubsection{Material Properties}

Figures 4-7 and 4-8 show each fuel plate containing (4 X 65) elements, each fuel wafer containing ( $2 \times 5)$ elements, and each flow channel containing ( 1 X 65) elements. However, the size ( 0.046166 inches) associated with each element in the $\mathrm{X}$ direction does not accurately represent the true thickness.

Since thermal resistance is proportional to a change in distance divided by the thermal conductivity of the material, a non-isotropic thermal conductivity can be derived for each 
material and applied corresponding to the coordinate axes used for the model. For example, in a two-dimensional (XY) model, a different thermal conductivity can be applied in the $\mathrm{X}$ direction versus the $\mathrm{Y}$ direction.

FIDAP supports both isotropic and non-isotropic thermal conductivity properties. For an isotropic conductivity property set, the conductivity is a scalar value. This value may be a complicated function of temperature or species concentration, but when used in the conservation of energy equation, it is represented by a single number at a given point in the model. Non-isotropic thermal conductivity is input through tensor notation. A fully non-symmetric tensor is supported; if only the diagonal terms are non-zero, an orthotropic conductivity model results.

External to the blanket fuel assembly the thermal model used isotropic thermal conductivities for air, helium, Zircaloy-4 and uranium oxide.

Internal to the blanket fuel sub-assemblies, the thermal model used orthotropic (nonisotropic) thermal conductivities for air, helium, Zircaloy, and uranium oxide. The nonisotropic thermal conductivity's were applied only in the $\mathrm{X}$ direction for those materials associated with the flow channels, cladding, and fuel wafers. This was necessary to retain the correct thermal resistance corresponding to the actual dimensions of the component. Isotropic thermal conductivity's were applied in the Y direction.

Two separate non-isotropic thermal conductivity's were derived for air and helium based on the different widths of the end and interior flow channels. For example, for the end channels, the nominal thermal conductivity of helium in the $\mathrm{X}$ direction was multiplied by 0.6995 (i.e., $0.046166 / 0.066$ ). Table $4-1$ summarizes the multipliers used to obtain the non-isotropic thermal conductivity for application in the $\mathrm{X}$ direction only. The $\mathrm{Y}$ direction thermal conductivity's remain unchanged from the nominal values.

\subsubsection{Heat Transfer}

Heat transfer can take place by one or more modes: conduction, convection, and radiation. The BFA thermal model uses two modes: conduction and radiation internal to the CSB storage tube. Convective heat transfer internal to the CSB storage tube was not explicitly calculated. Convective heat transfer from the external surface of the CSB storage tube was approximated by the application of a heat transfer coefficient. (To explicitly calculate the convective flow fields within the MCO or between the MCO and CSB would have required the development of an axi-symmetric or three-dimensional (3D) thermal-hydraulic model.)

\subsubsection{Internal}

The BFA thermal model assumes the energy gain mechanism is nuclear decay heat. The decay heat is assumed to be deposited $100 \%$ within the fuel wafers. Heat is transferred radially (two-dimensionally, $\mathrm{X}$ and $\mathrm{Y}$ ) by conduction or radiation from the interior of the blanket fuel assembly to the exterior surface of the CSB storage tube. For symmetry 
reasons, the $\mathrm{X}$ - and $\mathrm{Y}$-axes are modeled as adiabatic surfaces. Axial heat transfer is not modeled. However, a unit depth of one meter is assumed for the purposes of calculating the heat transfer surface areas and volumetric dependent terms such as the heat generation rate.

Heat transfer by conduction depends on the thermal conductivity of the material, surface area, and the temperature gradient across the material. Heat transfer by radiation involves a different physical mechanism based on the propagation of electromagnetic energy. Radiation depends on other parameters, such as the emissivity of the various surfaces, the geometrical relationship or view factors between the two surfaces, and the difference between the surface temperatures raised to the fourth power.

FIDAP can compute the radiation view factors between the various surfaces based on user input. However, the calculation can be very time consuming. The resulting radiation network couples every node on a given radiation surface to every other node on adjacent radiation surfaces and so forth. This quickly leads to a significant increase in computational time. Each time the geometry is changed, the view factors have to be recalculated.

Radiation view factors are typically calculated only once and supplied to each case via a separate input file.

\subsubsection{External}

The BFA thermal model assumes the only energy loss mechanism is convective heat transfer from the external surface of the CSB storage tube. Energy is removed from the BFA thermal model by the application of convective heat transfer coefficient to the external surface of the CSB storage tube and the specification of the environmental ambient temperature.

Radiation loss from the external surface of the storage tube was not modeled. The BFA thermal model assumes that the storage tube is positioned within an array of storage tubes, such that the net energy loss from radiation is zero.

The convective heat transfer coefficients applied to the external surface of the storage tube were derived from known correlation's for vertical cylinders, per Table 7-1 and Equations 7-28 and 7-29 on page 343 of HOLMAN 1990. The convective heat transfer coefficients are derived from correlation's dependent on air properties, the calculated wall temperature, known geometrical characteristics, and a fixed ambient temperature.

Table 4-3 presents the natural circulation (free convection) heat transfer coefficients that were derived for vertical cylinders at a constant wall temperature for two ambient temperatures, $110^{\circ} \mathrm{F}\left(316.5^{\circ} \mathrm{K}\right)$ and $140^{\circ} \mathrm{F}\left(333.2^{\circ} \mathrm{K}\right)$. For a vertical cylinder, the characteristic length was assumed equal to the heated fuel length of 96.5626 inches $(2.4527 \mathrm{~m})$. As shown in Table 4-3, when the wall temperature is equal to the ambient air temperature no heat transfer occurs and the heat transfer coefficient is zero. Energy 
would be added to the MCO if the wall temperature were less than the ambient air temperature. For energy to be removed from the MCO, the wall temperature must be greater than the ambient temperature.

\subsubsection{Decay Heat}

Table 4-2 summarizes the average volumetric heat generation rates $\left(\mathrm{J} / \mathrm{m}^{3}-\mathrm{s}\right)$ that were used for the thermal analyses. The average volumetric heat generation rates $\left(\mathrm{J} / \mathrm{m}^{3}-\mathrm{s}\right)$ were derived by dividing the blanket fuel assembly decay heat (Watts or $\mathrm{J} / \mathrm{s}$ ) by the fuel wafer volume $\left(\mathrm{m}^{3}\right)$. The fuel volume was derived using the dimensions shown in Figures 4-1 through 4-4. The blanket fuel assembly decay heat was obtained from Wittekind (1997) and Wittekind (1998).

Commercial pressurized light water reactors have a cosine shaped axial power distribution. Typical design values for a peak-to-average $(\mathrm{P} / \mathrm{A})$ axial power ratio range from 1.435 to 1.55 . The use of volumetric heat generation rates based on an average or flat decay heat distribution would underestimate peak temperatures. Table 4-2 also presents the volumetric heat generation rates for a peak-to-average axial multiplier of 1.55 .

It is conservative to assume a peak-to-average axial decay heat multiplier of 1.55 and a two-dimensional model with no axial heat transfer.

\subsubsection{Boundary Conditions}

The ambient environmental temperatures, $110^{\circ} \mathrm{F}\left(316.5^{\circ} \mathrm{K}\right)$ and $140^{\circ} \mathrm{F}\left(333.2^{\circ} \mathrm{K}\right)$, represent the boundary conditions applied to the external surface of the storage tube via a heat transfer coefficient. The minimum temperature cannot be less than the boundary condition.

Adiabatic boundary conditions were applied to the centerline of the spacer basket along the $\mathrm{X}$ - and $\mathrm{Y}$-axes. Energy transfer is allowed parallel to the $\mathrm{X}$ - and $\mathrm{Y}$-axes, but not across.

\subsection{Analysis Methodology}

Initially, two base case inputs were developed and debugged. These two cases were based on the maximum decay heat power, a peak-to-average axial decay heat multiplier of 1.00 , ambient environmental temperature of $140^{\circ} \mathrm{F}$, and two different backfill gases; helium and air. The radiation view factors were calculated and supplied to each file through a separate input file. Appendix A presents the input for the maximum decay heat air filled case.

The input for the remaining sixteen cases were developed from the two base cases by simply changing the input values for the title cards, decay heat, peak-to-average axial multiplier, and the ambient environmental temperature. 
A computer runscript was developed that automatically ran each of the remaining cases. Each case took approximately four hours to converge. Each individual case was postprocessed to obtain the results presented in Section 5.0. 
HNF-4109, Rev.0

Table 4-1.

Non-Isotropic Thermal Conductivity Multipliers

Component

Flow Channel - End

Flow Channel - Interior

Clad

Fuel Wafer
Multiplier

0.6995

0.5073

1.3190

0.9233 $\underline{\text { Material }}$

Air and helium

Air and helium

Zircaloy-4

Uranium Oxide 
HNF-4109, Rev.0

Table 4-2.

Volumetric Heat Generation Rate (W/ $\left.\mathrm{m}^{3}-\mathrm{s}\right)$ for Shippingport Blanket Fuel Assembly

\begin{tabular}{|c|c|c|c|}
\hline $\begin{array}{c}\text { Total Assembly } \\
\text { Decay Heat (W) }\end{array}$ & P/A & $\begin{array}{c}\text { Volumetric Heat } \\
\text { Generation Rate } \\
\left(\mathrm{J} / \mathrm{m}^{3}-\mathrm{s}\right)\end{array}$ & $\begin{array}{c}\text { Assembly Decay } \\
\text { Heat (W) for a Unit } \\
\text { Depth of 1.0m }\end{array}$ \\
\hline 93.39 & 1.00 & 4261.39 & 38.07 \\
\hline 99.69 & 1.55 & 6605.16 & 59.02 \\
\hline 151.70 & 1.00 & 4548.86 & 40.65 \\
& 1.55 & 7050.73 & 63.00 \\
\hline 164.70 & 1.00 & 6922.08 & 61.85 \\
& 1.55 & 10729.22 & 95.87 \\
\hline & 1.00 & 7515.27 & 67.15 \\
\hline
\end{tabular}


HNF-4109, Rev.0

Table 4-3

Heat Transfer Coefficients for a Vertical Cylinder for Various Wall Temperatures Given Two Ambient Conditions

\begin{tabular}{|c|c|c|c|}
\hline & & \multicolumn{2}{|c|}{ Heat Transfer Coefficient $\left(\mathrm{W} / \mathrm{m}^{2}-^{\circ} \mathrm{K}\right)$} \\
\hline \multicolumn{2}{|c|}{$\mathrm{T}_{\text {wall, }}{ }^{\circ} \mathrm{F}\left({ }^{\circ} \mathrm{K}\right)$} & $T_{a m b}=110^{\circ} \mathrm{F}\left(316.5^{\circ} \mathrm{K}\right)$ & $\mathrm{T}_{\mathrm{amb}}=140^{\circ} \mathrm{F}\left(333.2^{\circ} \mathrm{K}\right)$ \\
\hline 32.0 & $(273.15)$ & 4.469 & 4.869 \\
\hline 49.7 & $(283.0)$ & 4.042 & 4.513 \\
\hline 68.0 & $(293.15)$ & 3.542 & 4.145 \\
\hline 80.6 & $(300.15)$ & 3.117 & 3.862 \\
\hline 98.3 & $(310.0)$ & 2.256 & 3.393 \\
\hline 107.3 & $(315.0)$ & 1.372 & 3,113 \\
\hline 111.8 & $(317.5)$ & 1.209 & 2.955 \\
\hline 116.3 & $(320.0)$ & 1.825 & 2.781 \\
\hline 125.3 & $(325.0)$ & 2.435 & 2.359 \\
\hline 134.3 & $(330.0)$ & 2.826 & 1.709 \\
\hline 137.9 & $(332.0)$ & 2.953 & 1.219 \\
\hline 143.3 & $(335.0)$ & 3.123 & 1.424 \\
\hline 152.3 & $(340.0)$ & 3.365 & 2.191 \\
\hline 170.3 & $(350.0)$ & 3.747 & 2.926 \\
\hline 188.3 & $(360.0)$ & 4.044 & 3.379 \\
\hline 206.3 & $(370.0)$ & 4.285 & $3 . \overline{712}$ \\
\hline 224.3 & $(380.0)$ & 4.485 & 3.974 \\
\hline 242.3 & $(390.0)$ & 4.655 & 4.188 \\
\hline 260.3 & $(400.0)$ & 4.800 & 4.367 \\
\hline 278.3 & $(410.0)$ & 4.924 & 4.535 \\
\hline 296.3 & $(420.0)$ & 5.038 & 4.683 \\
\hline 314.3 & $(430.0)$ & 5.150 & 4.813 \\
\hline 332.3 & $(440.0)$ & 5.251 & 4.929 \\
\hline 350.3 & $(450.0)$ & 5.341 & 5.031 \\
\hline 395.3 & $(475.0)$ & 5.526 & 5.240 \\
\hline 440.3 & $(500.0)$ & 5.662 & 5.393 \\
\hline 530.3 & $(550.0)$ & 5.868 & 5.654 \\
\hline 620.3 & $(600.0)$ & 6.022 & 5.821 \\
\hline
\end{tabular}


HNF-4109, Rev.0

Figure 4-1.

Plan and Selection View of a MCO Containing

Four Shippingport Blanket Fuel Assemblies

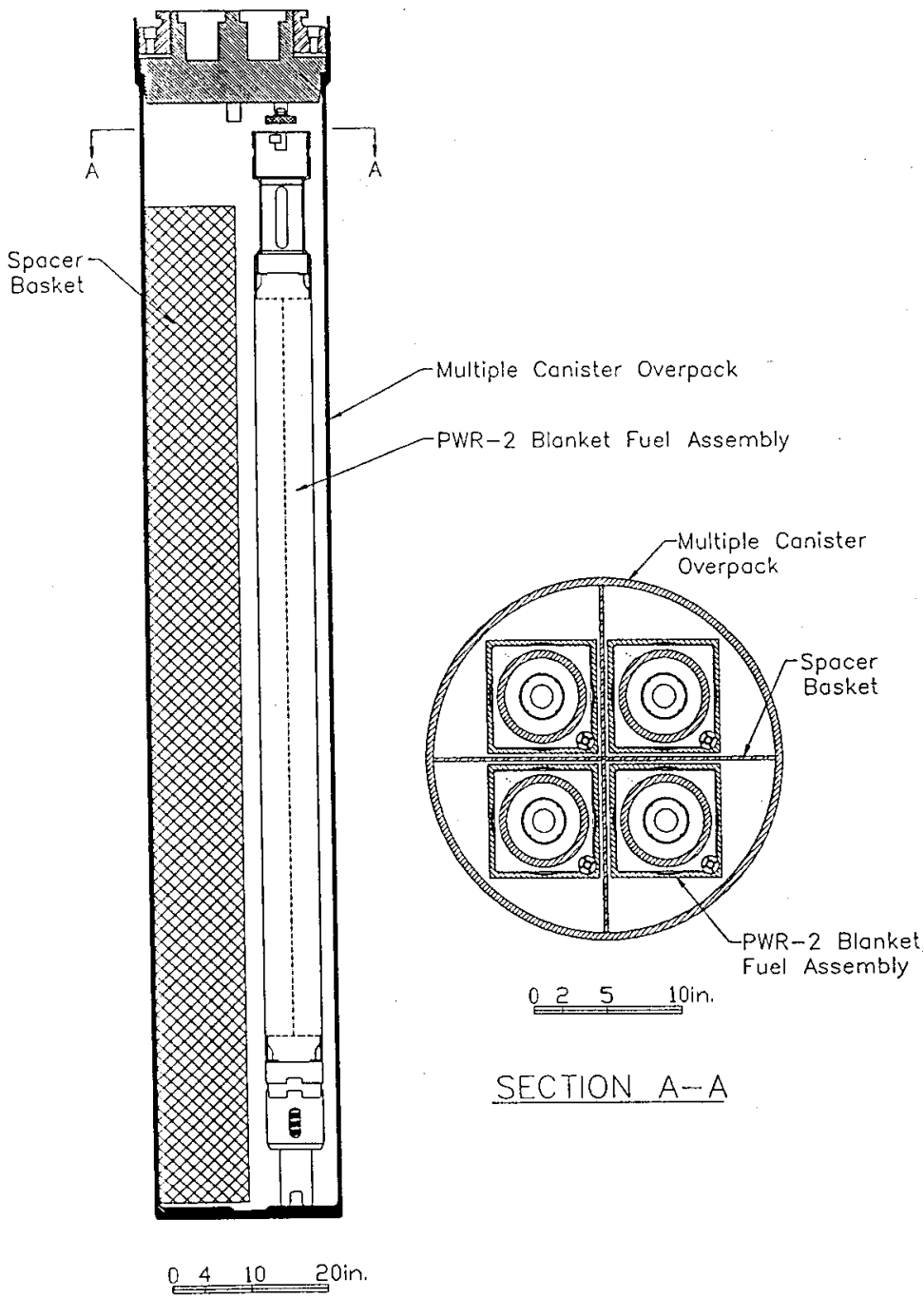


HNF-4109, Rev.0

Figure 4-2.

Isometric View of Shippingport Blanket Fuel Assembly

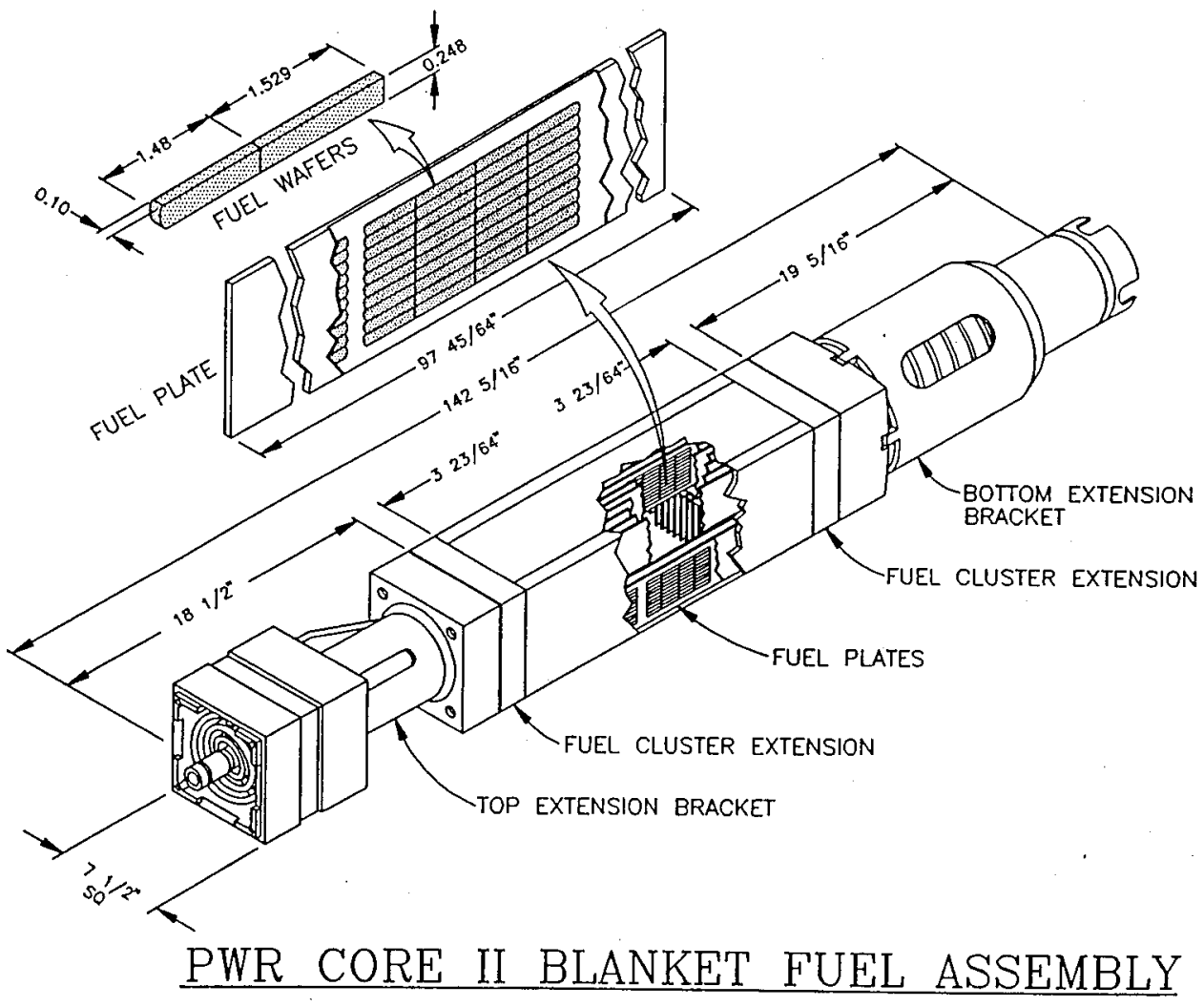


HNF-4109, Rev.0

Figure 4-3.

Blanket Fuel Assembly Cluster Details
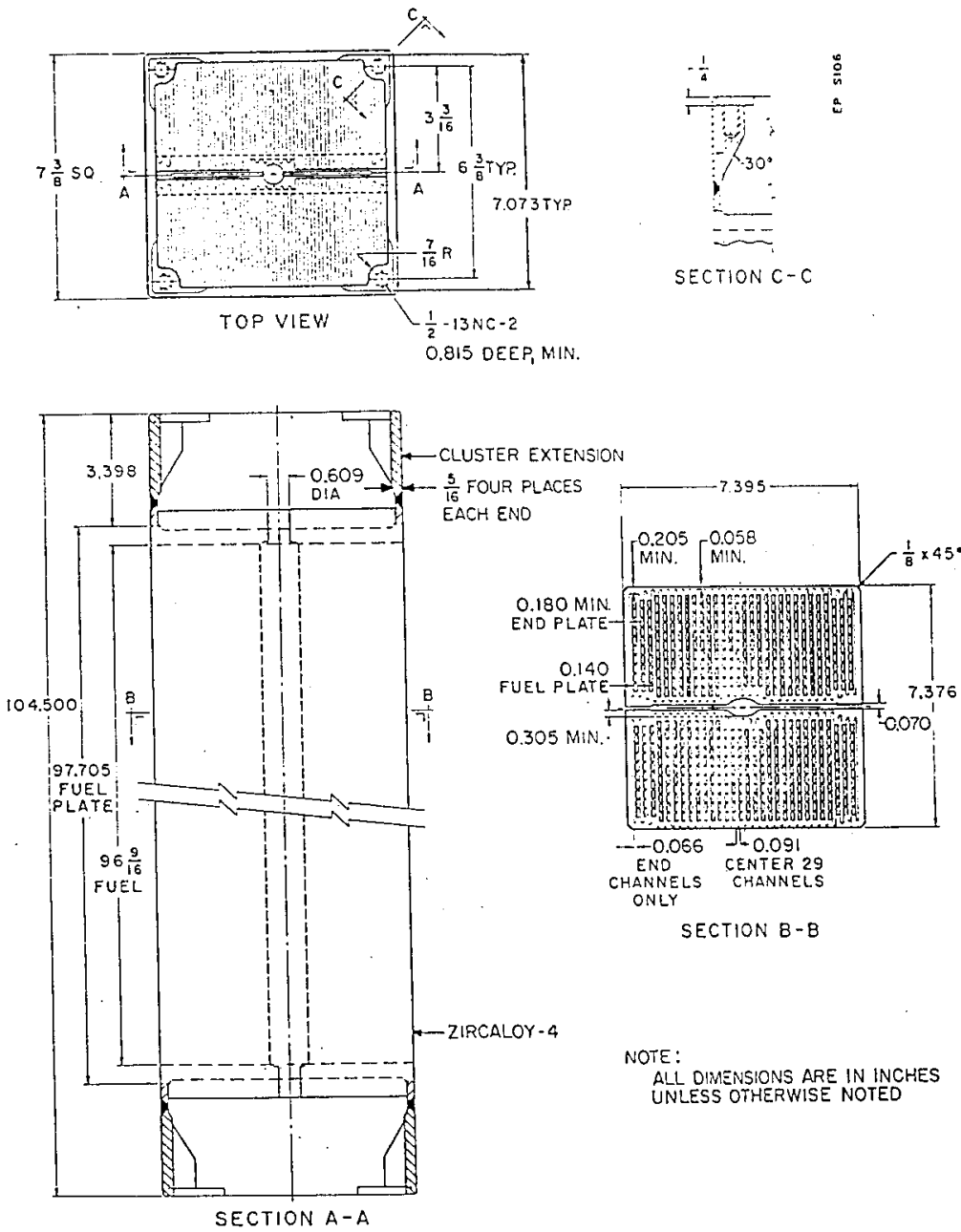


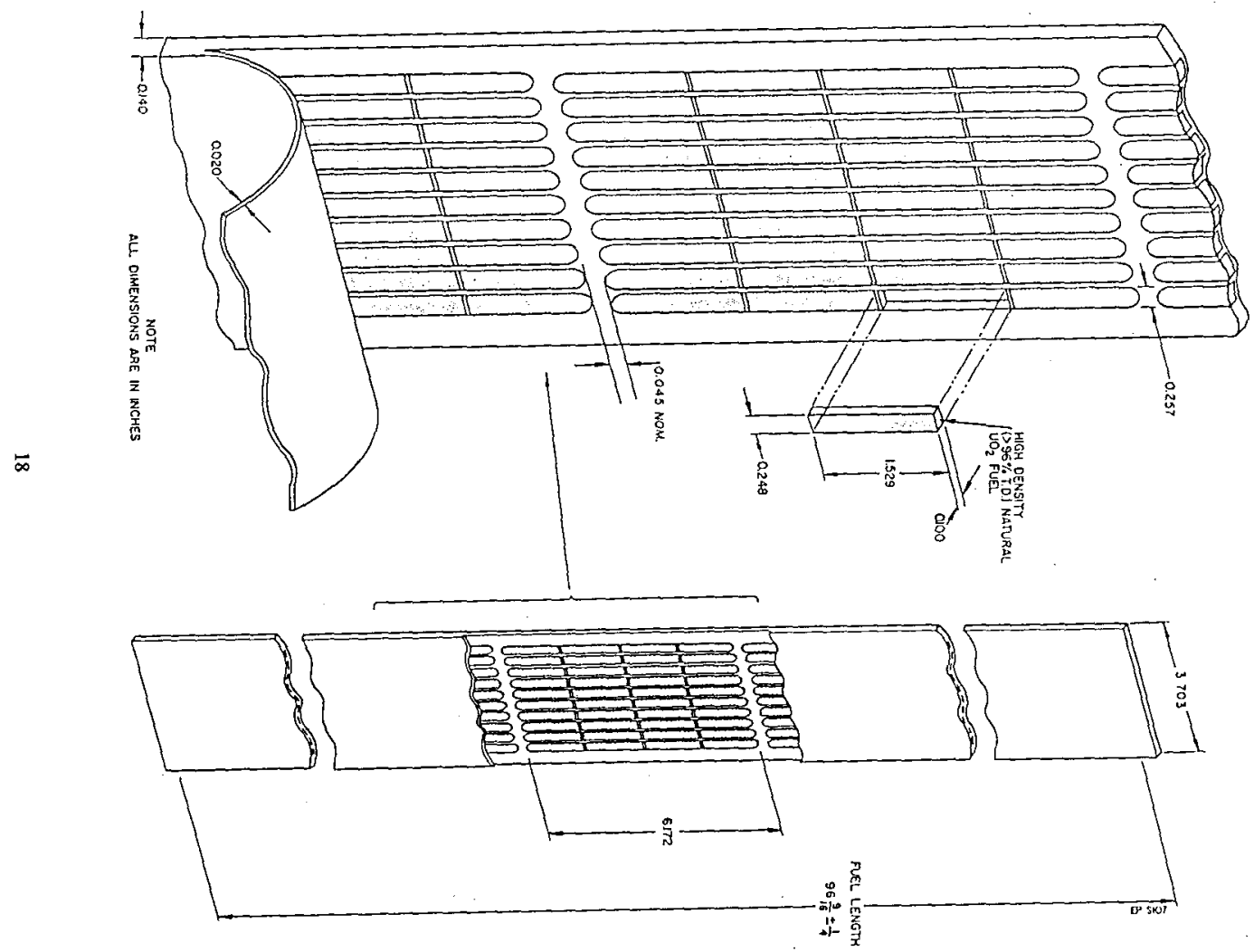


HNF-4109, Rev.0

Figure 4-5.

Outline of Major Components Within Thermal Model

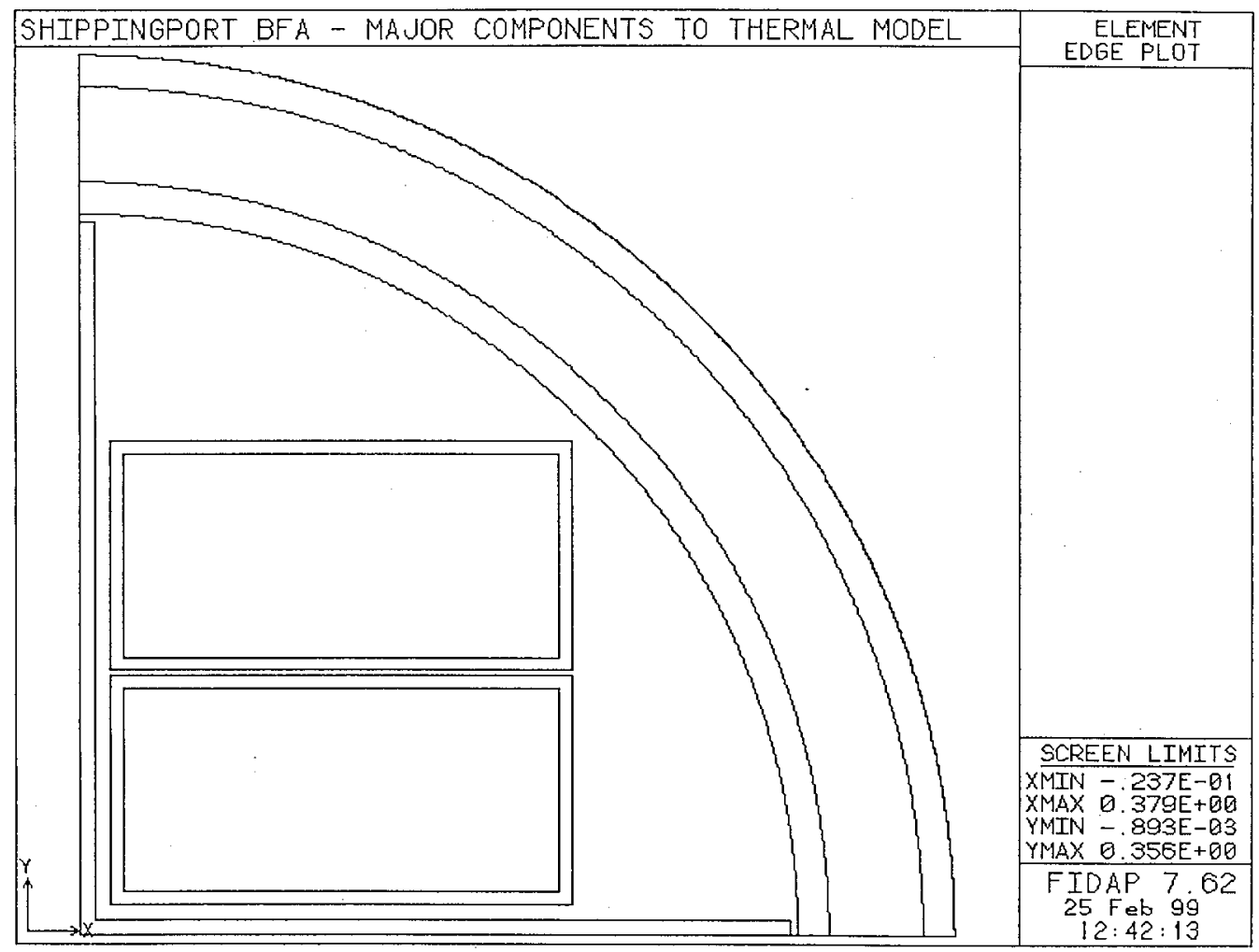


HNF-4109, Rev.0

Figure 4-6.

Detailed Outline of Blanket Fuel Assembly

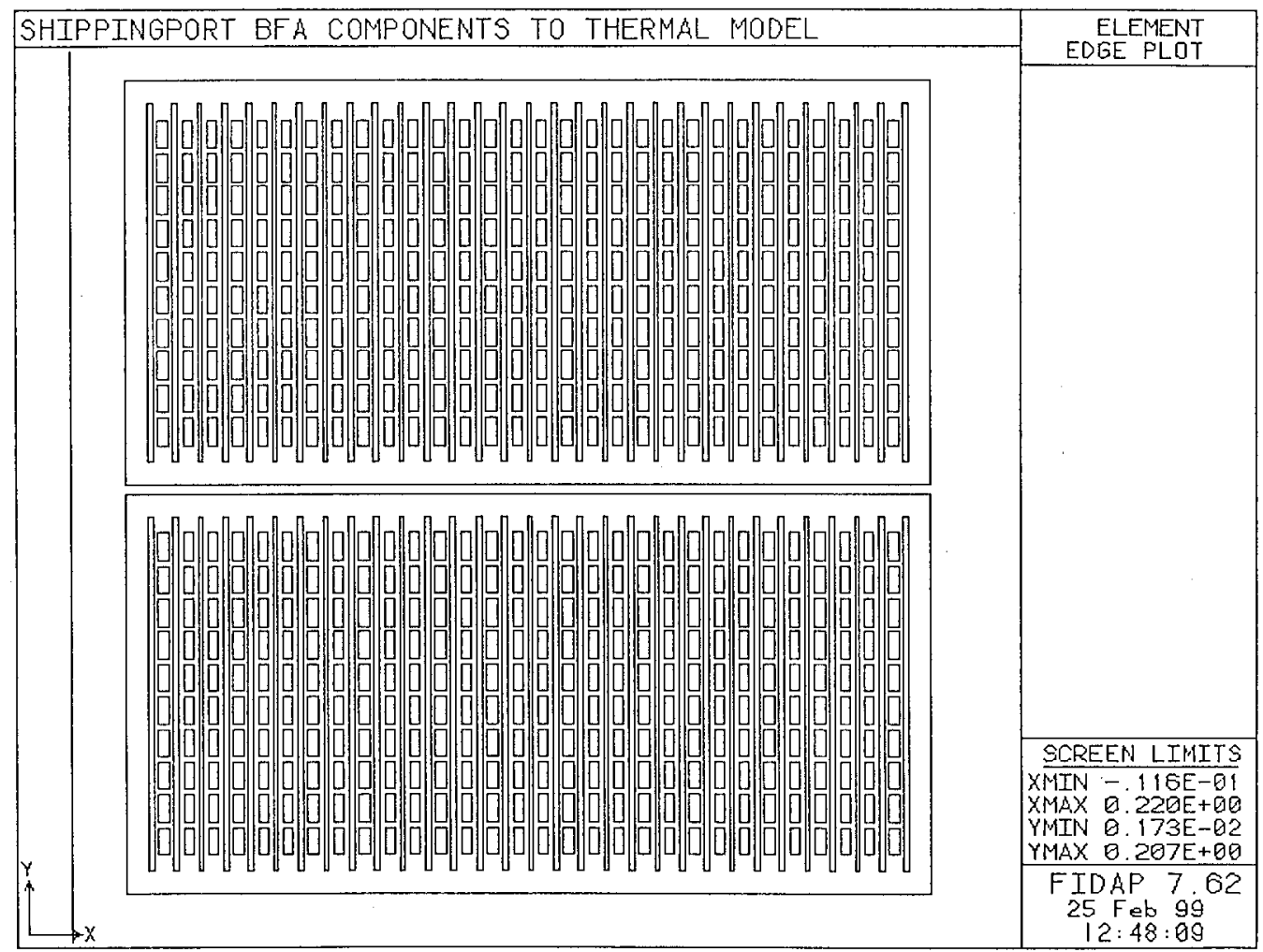


HNF-4109, Rev.0

Figure 4-7.

Blanket Fuel Sub-Assembly Mesh Within Fuel Wafers

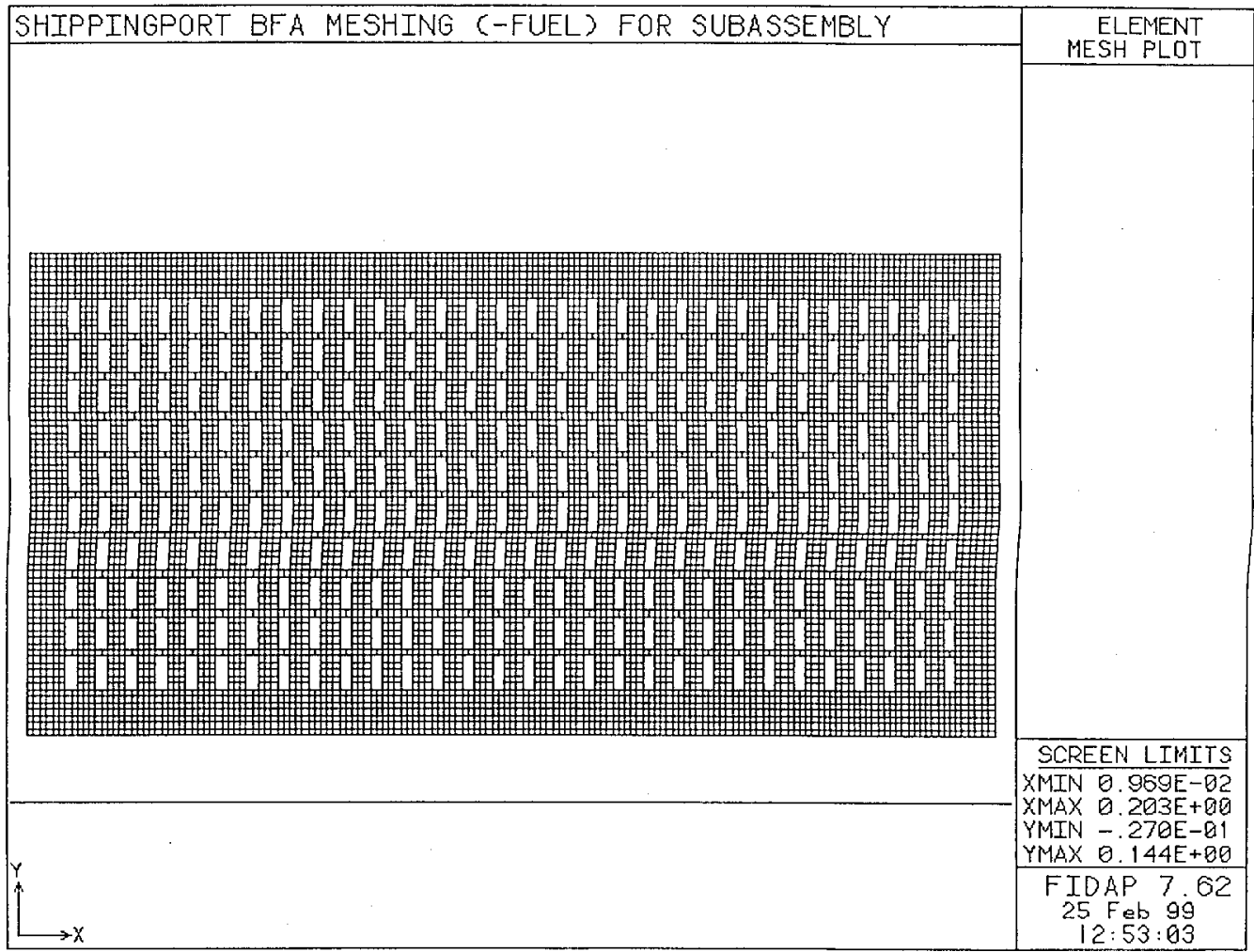


HNF-4109, Rev.0

Figure 4-8.

Blanket Fuel Sub-Assembly Mesh for Fuel Wafers Only

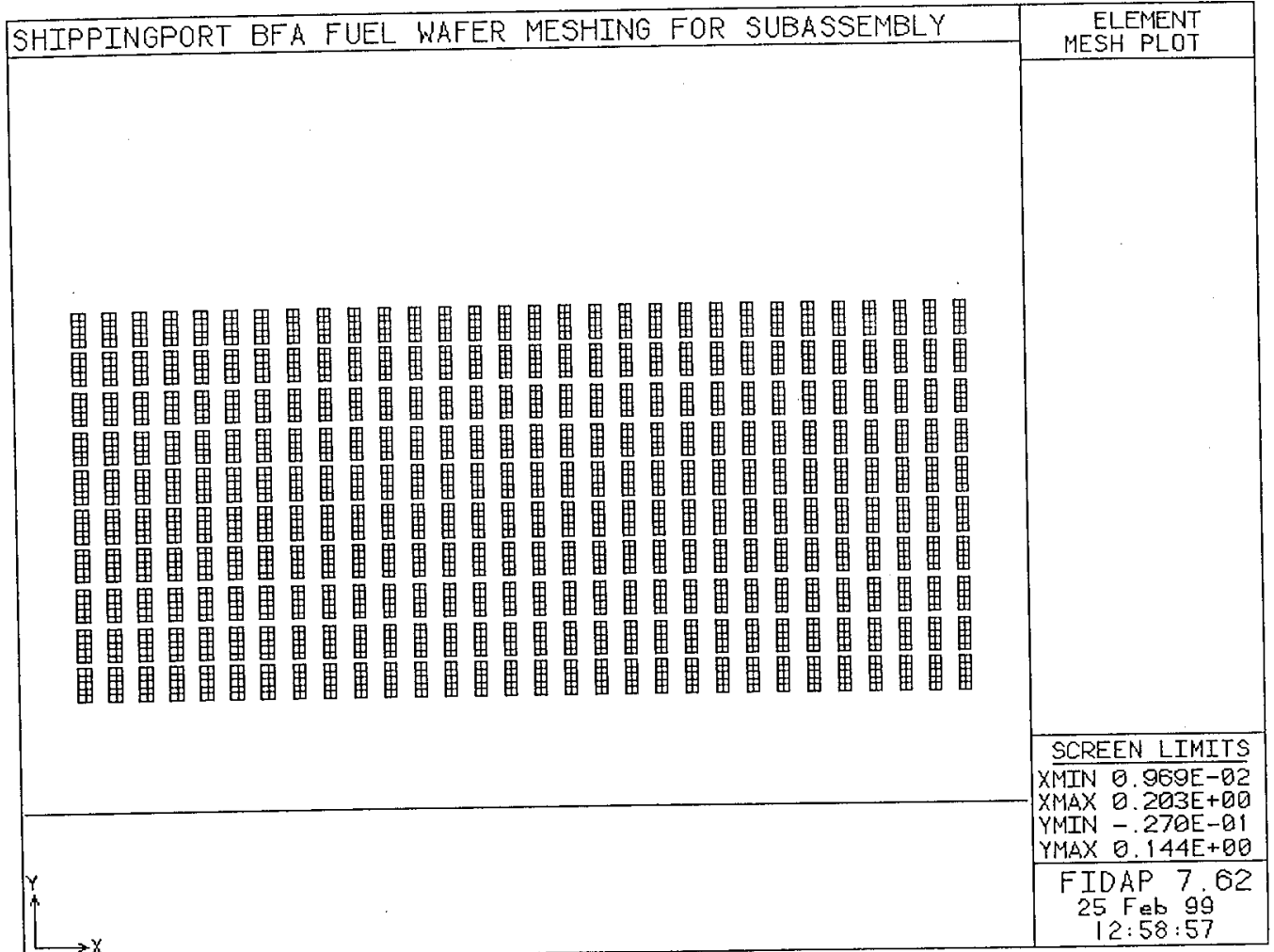




\subsection{RESULTS}

The results of the steady-state thermal analyses for the Shippingport Blanket Fuel Assemblies are presented in the following sections. The results have been separated into two sections depending on the backfill gas that was used: helium or air. Section 5.1 presents the results for helium. Section 5.2 presents the results for air. The emphasis in the following sections is on peak temperatures. This assumes that the peak fuel temperature resulting from each analysis is representative of the peak cladding surface temperature. This is supported by a close inspection of the results, which shows that the peak fuel temperature is within a few tenths of a degree of the peak cladding surface temperature. This is due to the high thermal conductivity of the Zircaloy-4 cladding and the thin fuel wafers.

The analyses were performed using a quarter-symmetric two-dimensional finite element model of a single Shippingport BFA within a Multi-Canister Overpack (MCO) within a Canister Storage Building (CSB) storage tube.

The total assembly decay heat ranged from 93.39 to 164.70 Watts. Peak-to-average (P/A) axial multipliers of 1.00 and 1.55 were used to derive the corresponding volumetric heat generation rate for input to the thermal model. The peak ambient air temperature within the CSB ranged from $110^{\circ} \mathrm{F}\left(316.48^{\circ} \mathrm{K}\right)$ to $140^{\circ} \mathrm{F}\left(333.15^{\circ} \mathrm{K}\right)$.

In each case, an energy balance was performed to confirm that the energy produced and removed from the energy model was in agreement with the values used to calculate the heat transfer coefficients.

\subsection{Helium Backfill}

Table 5-1 presents the results of the steady-state thermal analyses that were performed for the Shippingport Blanket Fuel Assemblies (BFA) with helium as the backfill gas.

Helium was assumed internal to the MCO and within the gap between the MCO and CSB storage tube.

Figure 5-1 presents a contour plot of the maximum steady-state temperature distribution for the worst case conditions: maximum decay heat of 164.7 watts per assembly, a P/A multiplier of 1.55 , and a maximum peak ambient temperature of $140 \mathrm{~F}$. The maximum peak cladding temperature was determined to be $335.9^{\circ} \mathrm{F}\left(442.0^{\circ} \mathrm{K}\right)$. Figure $5-1$ was derived based on subdividing the range of the results from the minimum to maximum temperature into twenty divisions. The contours represent the midpoints within each temperature division. Note that the spacer basket acts like a large fin removing energy from the center of the MCO.

Figure 5-2 presents a contour plot of the steady-state temperature distribution for the minimum worst case conditions: decay heat of 93.39 watts per assembly, a P/A multiplier of 1.00 , and an ambient temperature of $110^{\circ} \mathrm{F}\left(316.5^{\circ} \mathrm{K}\right)$. The minimum peak cladding temperature was determined to be $197.9^{\circ} \mathrm{F}\left(365.3^{\circ} \mathrm{K}\right)$. 
With reference to Figures 4-5 and 4-6, Figures 5-1 and 5-2 indicate that the temperature gradient of across the blanket fuel assembly is relatively flat. The largest temperature gradients occur across the gaps between the MCO and CSB storage tube and between the BFA and MCO.

Figure 5-3 presents a contour plot of the steady-state temperature conditions associated with the base case conditions for helium. Figure 5-3 does not represent the worst case conditions, but indicates that the same type of temperature distribution exists as in Figures 5-1 and 5-2. Only the magnitude of the peak temperature differs. Figure 5-4 presents a contour temperature plot of the area near the center of the BFA thermal model. Figure 5-4 is actually an enlargement of Figure 5-3, but is based on the temperature distribution within the enlarged area. The two halves of the BFA are discernable along with the small gap between them. The affects of the spacer basket are also shown along each axis. The spacer basket acts like a large fin removing energy from the center of the MCO. The temperature distribution across the BFA actually shows a slight decrease for those areas nearest the spacer basket.

Figure 5-5 presents the concept of a line plot running through the point of peak temperature. Figures 5-6 and 5-7 present temperature versus distance for a line running through the peak temperature and parallel to the $\mathrm{X}$ - and $\mathrm{Y}$ - axis, respectively. Figures 56 and 5-7 allow a more detailed inspection of the radial temperature distribution through the blanket fuel assembly to the CSB storage tube.

Figure 5-6 presents the temperature distribution in the $X$ direction running through the point of peak temperature. The peak temperature shown in Figure 5-6 agrees with Table 5-1. The small temperature gradient within the BFA is shown, as well as the steeper gradients associated with the helium gaps. Very little temperature drops occurs across the MCO and canister storage tube, because of the high thermal conductivity of stainless and mild carbon steels. Near the origin, the temperature decreases slightly. This is due to the spacer basket acting as a conduction fin.

Figure 5-7 presents a similar temperature distribution in the $\mathrm{Y}$ direction running through the point of peak temperature. Again, the peak temperature shown in Figure 5-7 agrees with Table 5-1. Figure 5-7 shows a small temperature change between the two halves of the blanket fuel assembly. This is due to the small gap between the two halves. Near the origin, the temperature decreases slightly. This is due to the spacer basket acting as a conduction fin.

\subsection{Air Backfill}

Table 5-1 presents the results of the steady-state thermal analyses that were performed for the Shippingport Blanket Fuel Assemblies (BFA) with dry air as the backfill gas. Dry air was assumed internal to the $\mathrm{MCO}$ and within the gap between the MCO and CSB storage tube. 
Figure 5-8 presents a contour plot of the steady-state temperature distribution for the maximum worst case conditions: decay heat of 164.7 watts per assembly, a P/A multiplier of 1.55 , and an ambient temperature of $333.2^{\circ} \mathrm{K}\left(140^{\circ} \mathrm{F}\right)$. The maximum peak cladding temperature was determined to be $410.5^{\circ} \mathrm{F}\left(483.4^{\circ} \mathrm{K}\right)$. Figure $5-8$ was derived based on subdividing the range of the results from the minimum to maximum temperature into twenty divisions. The contours represent the midpoints within each temperature division. Note that the spacer basket acts like a large fin removing energy from the center of the MCO.

Figure 5-9 presents a contour plot of the steady-state temperature distribution for the minimum worst case conditions: decay heat of 93.39 watts per assembly, a P/A multiplier of 1.00 , and an ambient temperature of $316.5^{\circ} \mathrm{K}\left(110^{\circ} \mathrm{F}\right)$. The minimum peak cladding temperature was determined to be $247.1^{\circ} \mathrm{F}\left(392.6^{\circ} \mathrm{K}\right)$.

With reference to Figures 4-5 and 4-6, Figures 5-8 and 5-9 indicate that the temperature gradient of across the blanket fuel assembly is relatively flat. The largest temperature gradients occur across the gap between the MCO and CSB storage tube and between the BFA and MCO.

A comparison of Figures 5-8 and 5-9 with Figures 5-1 and 5-2 show the same minimum temperature, but steeper temperature gradients. This is expected given the reduced thermal conductivity of dry air relative to helium. Helium reduces the peak cladding temperature by a maximum of approximately $75^{\circ} \mathrm{F}\left(41.4^{\circ} \mathrm{K}\right)$ for the worst case conditions presented within Table 5-1.

Figure 5-10 presents a contour plot of the steady-state temperature conditions associated with the base case conditions for air. Figure 5-10 does not represent the worst case conditions, but indicates that the same type of temperature distribution exists as in Figures 5-8 and 5-9. Only the magnitude of the peak temperature differs.

Figure 5-11 presents a contour temperature plot of the area near the center of the BFA thermal model. Figure 5-11 is actually an enlargement of Figure 5-10, but is based on the temperature distribution within the enlarged area. The two halves of the BFA are discemable along with the small gap between them. The affects of the spacer basket are also shown along each axis. The temperature distribution across the BFA actually shows a slight decrease for those areas nearest the spacer basket. The spacer basket acts like a large fin removing energy from the center of the MCO.

Figure 5-6 and 5-7 are representative of the temperature distributions expected for the air filled cases. The peak temperature will be higher for an air filled MCO and CSB storage tube and the temperature gradients will be steeper across the air gaps, but the general overall shape will be similar to the helium cases, as discussed in Section 5.1. 


\subsection{Comparison of Hand Calculations with Simulation Results}

A series of iterative hand calculations were performed to check the results presented in Sections 5.1 and 5.2 for the base cases associated with helium and air. Table 5-2 summarizes the comparison between the results of the numerical simulation and hand calculations.

The hand calculations were performed assuming a blanket fuel assembly decay heat of 164.7 watts, a peak-to-average decay heat value of 1.00 , and an ambient temperature of $140^{\circ} \mathrm{F}\left(333.2^{\circ} \mathrm{K}\right)$. Different backfill gases were used: helium and dry air. The classical forms of Fourier's Law of Heat Transfer for cylindrical and slab geometry were used to estimate the temperature rise across each component. Some iteration was necessary to determine the surface temperature when accounting for thermal radiation across a helium or dry air filled gap.

Very good agreement is shown. The maximum difference of $17.1^{\circ} \mathrm{F}\left(9.5^{\circ} \mathrm{K}\right)$ was noted for the outer wall of the blanket fuel assembly. This difference is a result of trying to estimate the temperature rise across the wedge shaped gap between the perimeter of the BFA and the ID of the MCO. The hand calculations were performed based on an average gap of 2.74 inches: whereas, the numerical thermal model accounted for the variable width.

Based on the agreement between the results of the hand calculations and the numerical simulation, the BFA thermal model was properly developed. Therefore, since each case is identical except for input differences associated with the decay heat, backfill, and ambient temperature, the results presented in Table 5-1 are considered reasonable and accurate for the given assumptions and conditions. 


\section{Table 5-1.}

Peak Cladding Temperatures for the Shippingport Blanket Fuel Assemblies At Steady-State Conditions Within A

Multi-Canister Overpack Within the Canister Storage Building

\begin{tabular}{|c|c|c|c|c|c|c|c|}
\hline \multirow[b]{2}{*}{$\begin{array}{l}\text { Blanket Fuel } \\
\text { Assembly Decay } \\
\text { Heat (watts) }\end{array}$} & \multirow[b]{2}{*}{$\begin{array}{c}\text { Axial } \\
\text { P/A }\end{array}$} & \multirow{2}{*}{\multicolumn{2}{|c|}{$\begin{array}{l}\text { Ambient CSB Vault Air } \\
\text { Temperature, }{ }^{\circ} \mathrm{F}\left({ }^{\circ} \mathrm{K}\right)\end{array}$}} & \multicolumn{4}{|c|}{$\begin{array}{c}\text { Peak Cladding Temperature, }{ }^{\circ} \mathrm{F}\left({ }^{\circ} \mathrm{K}\right) \text { for Various Back } \\
\text { Fill Gases }\end{array}$} \\
\hline & & & & & & & Air \\
\hline 93.39 & $\begin{array}{l}1.00 \\
1.55 \\
\end{array}$ & $\begin{array}{l}110 \\
140 \\
\end{array}$ & $\begin{array}{l}(316.5) \\
(333.2)\end{array}$ & $\begin{array}{l}197.9 \\
264.1 \\
\end{array}$ & $\begin{array}{c}(365.3)^{*} \\
(402.1\end{array}$ & $\begin{array}{l}247.1 \\
320.9 \\
\end{array}$ & $\begin{array}{l}(392.6) \\
(433.7) \\
\end{array}$ \\
\hline 99.69 & $\begin{array}{l}1.00 \\
1.55\end{array}$ & $\begin{array}{l}110 \\
140\end{array}$ & $\begin{array}{l}(316.5) \\
(333.2)\end{array}$ & $\begin{array}{l}202.9 \\
270.9\end{array}$ & $\begin{array}{l}(368.1) \\
(405.9)\end{array}$ & $\begin{array}{l}254.1 \\
329.8\end{array}$ & $\begin{array}{l}(396.5) \\
(438.6)\end{array}$ \\
\hline 151.70 & $\begin{array}{l}1.00 \\
1.55\end{array}$ & $\begin{array}{l}110 \\
140\end{array}$ & $\begin{array}{l}(316.5) \\
(333.2)\end{array}$ & $\begin{array}{l}241.7 \\
323.6\end{array}$ & $\begin{array}{l}(389.6) \\
(435.2)\end{array}$ & $\begin{array}{l}306.8 \\
395.8\end{array}$ & $\begin{array}{l}(425.8) \\
(475.3)\end{array}$ \\
\hline 164.70 & $\begin{array}{l}1.00 \\
1.00 \\
1.55\end{array}$ & $\begin{array}{l}110 \\
140 \\
140\end{array}$ & $\begin{array}{l}(316.5) \\
(333.2) \\
(333.2)\end{array}$ & $\begin{array}{l}250.8 \\
277.9 \\
335.9\end{array}$ & $\begin{array}{l}(394.7) \\
(409.8) \\
(442.0)\end{array}$ & $\begin{array}{l}318.5 \\
338.7 \\
410.5\end{array}$ & $\begin{array}{c}(432.3) \\
(443.6) \\
(483.4)^{* *}\end{array}$ \\
\hline
\end{tabular}

* Maximum Peak Cladding Temperature (Helium)

** Maximum Peak Cladding Temperature (Air) 
Table 5-2.

Comparison of Hand Calculations with Base Case Simulation

Results for Helium and Dry Air Backfill

(Decay Heat $=164.7$ Watts, $\mathrm{P} / \mathrm{A}=1.00, \mathrm{~T}_{\mathrm{amb}}=140^{\circ} \mathrm{F}\left(333.2^{\circ} \mathrm{K}\right)$ )

\begin{tabular}{|c|c|c|c|c|c|c|c|}
\hline & \multicolumn{3}{|c|}{ Helium } & \multicolumn{4}{|c|}{ Dry Air } \\
\hline Component & Hand Calc., ${ }^{\circ} \mathrm{F}\left({ }^{\circ} \mathbf{K}\right)$ & FID & $\mathrm{F}\left({ }^{\circ} \mathrm{K}\right)$ & Hand & ${ }^{\circ} \mathrm{F}\left({ }^{\circ} \mathrm{K}\right)$ & FID & $\mathrm{F}\left({ }^{\circ} \mathbf{K}\right)$ \\
\hline OD-Storage Tube & $(366.5)$ & 200.0 & $(366.5)$ & 200.0 & $(366.5)$ & 200.0 & $(366.5)$ \\
\hline ID-Storage Tube & $(366.6)$ & 200.4 & $(366.7)$ & 200.2 & $(366.6)$ & 200.4 & $(366.7)$ \\
\hline ID-MCO & $(386.0)$ & 235.5 & $(386.2)$ & 272.2 & $(406.6)$ & 271.0 & (405.9) \\
\hline OD-Blanket Assy. & $(414.0)^{*}$ & 268.4 & $(404.5)^{*}$ & 326.6 & $(436.8)$ & 336.7 & (442.4) \\
\hline Peak & $(416.8)$ & 278.0 & $(409.8)$ & 338.8 & $(443.6)$ & 341.7 & $(445.2)$ \\
\hline
\end{tabular}

* Maximum Difference of $17.1^{\circ} \mathrm{F}\left(9.5^{\circ} \mathrm{K}\right)$ 
HNF-4109, Rev.0

Figure 5-1.

Temperature Contour Plot for Helium Backfill - Maximum Conditions

(Decay Heat $=164.7$ Watts, $\mathrm{P} / \mathrm{A}=1.55, \mathrm{~T}_{\text {amb }}=140^{\circ} \mathrm{F}\left(333.2^{\circ} \mathrm{K}\right)$ )

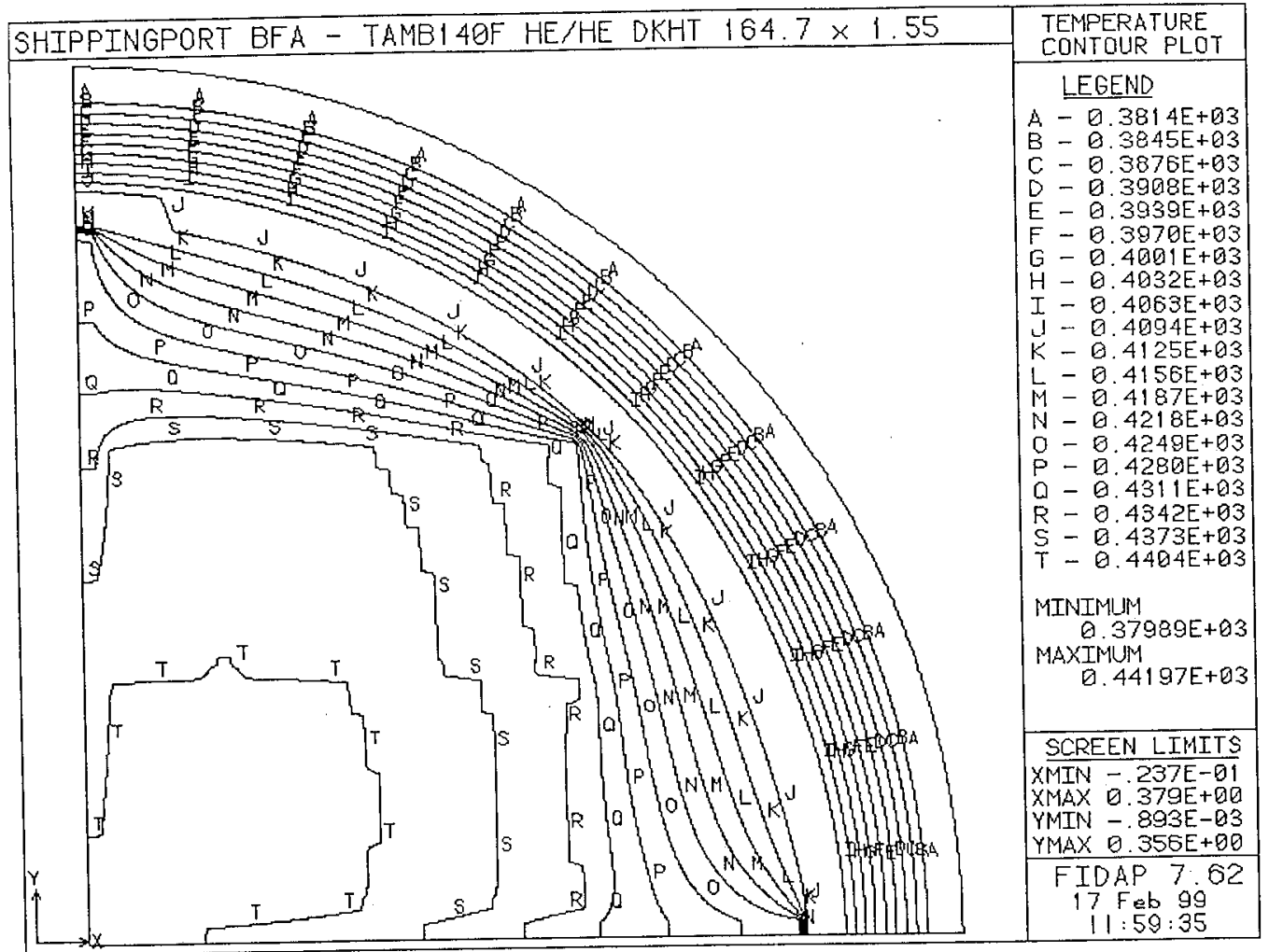


HNF-4109, Rev.0

Figure 5-2.

Temperature Contour Plot for Helium Backfill - Minimum Conditions

$\left(\right.$ Decay Heat $=93.39$ Watts, $\mathrm{P} / \mathrm{A}=1.00, \mathrm{~T}_{\text {amb }}=110^{\circ} \mathrm{F}\left(316.5^{\circ} \mathrm{K}\right)$ )

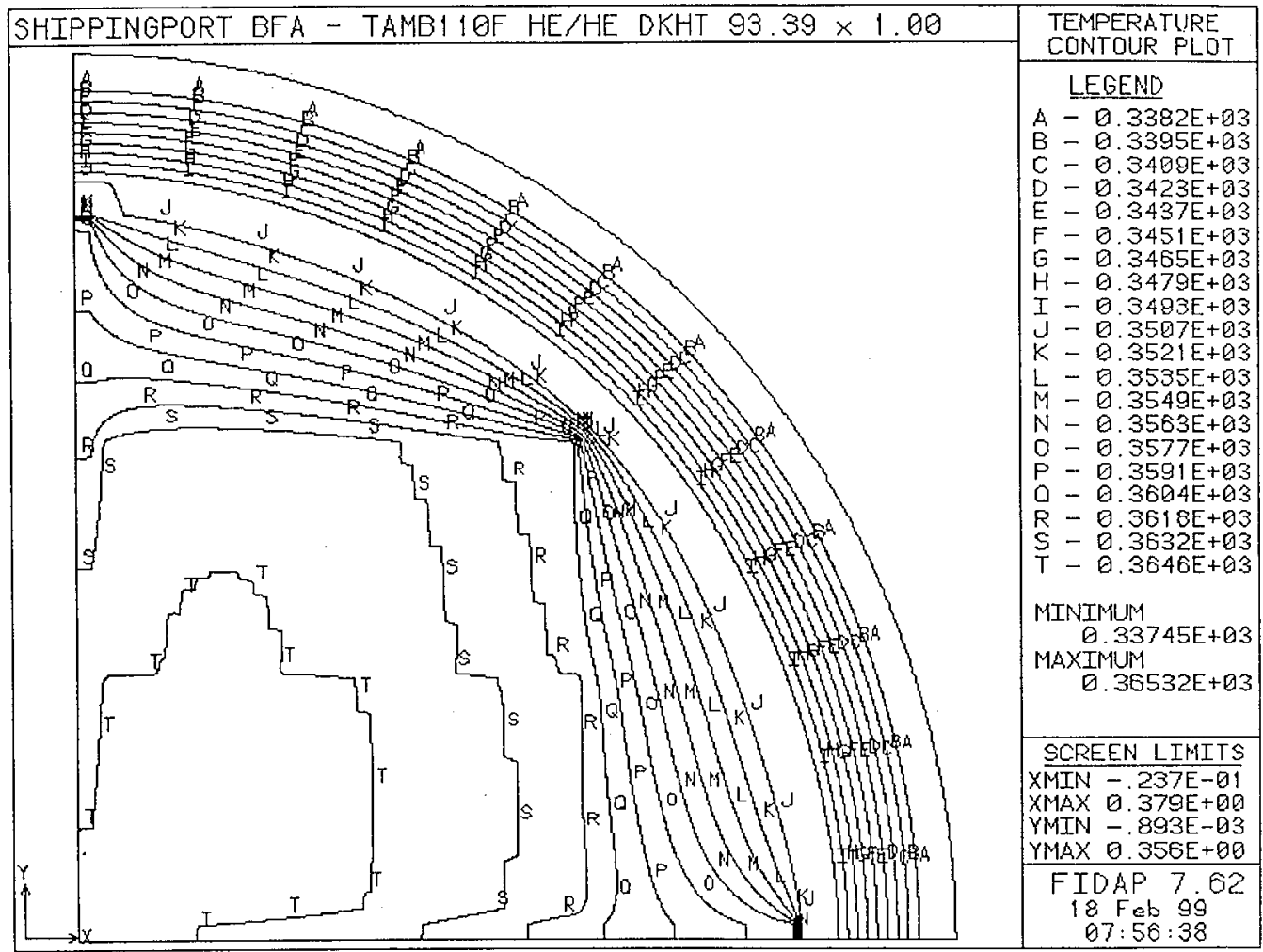


HNF-4109, Rev.0

Figure 5-3.

Temperature Contour Plot for Helium Backfill Base Case Conditions

(Decay Heat $=164.7$ Watts, $\mathrm{P} / \mathrm{A}=1.00, \mathrm{~T}_{\mathrm{amb}}=140^{\circ} \mathrm{F}\left(333.2^{\circ} \mathrm{K}\right)$ )

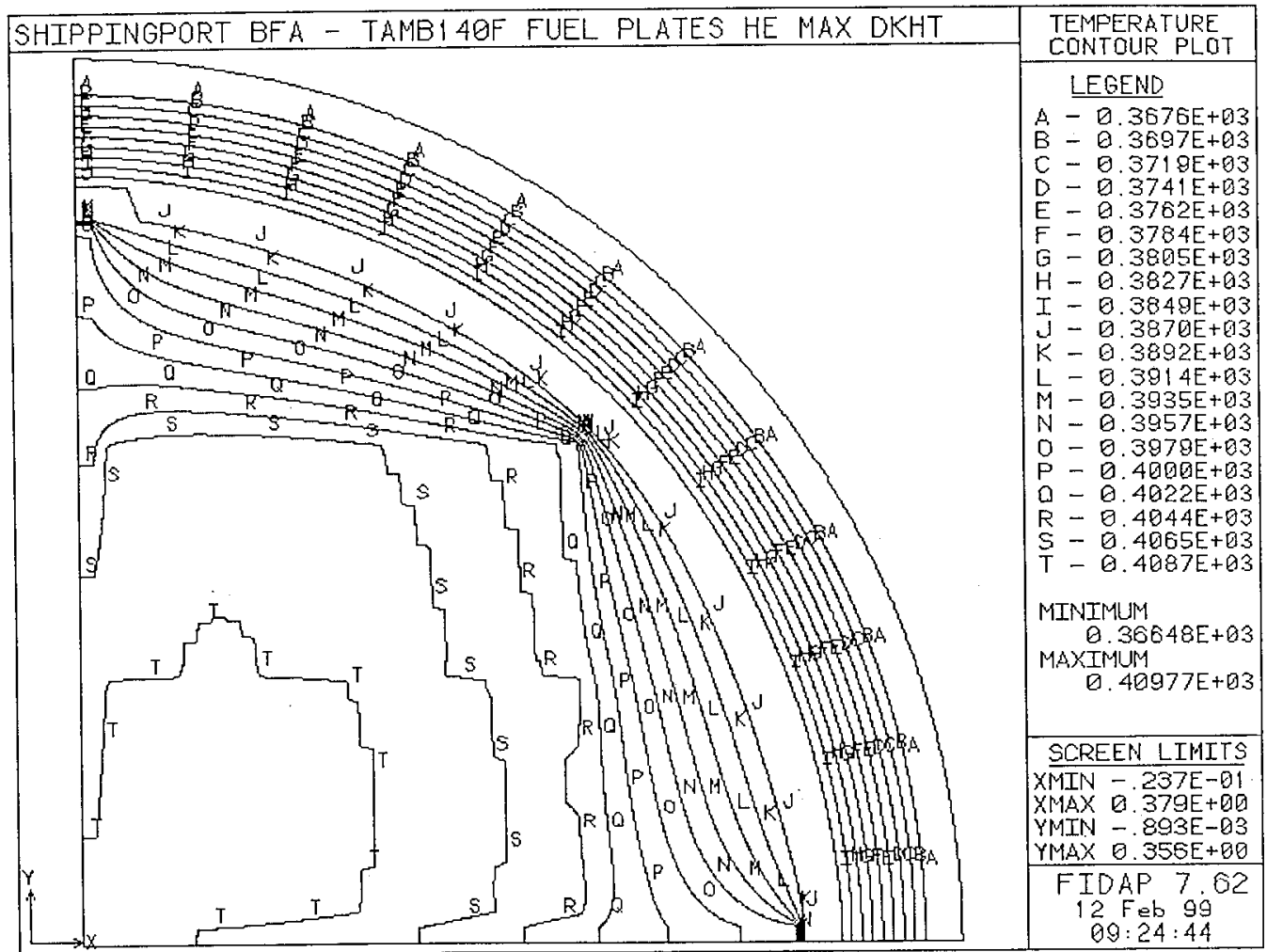


Figure 5-4.

Temperature Contour Plot for Helium Backfill

Base Case Conditions Near Center of MCO

(Decay Heat $=164.7$ Watts, $\mathrm{P} / \mathrm{A}=1.00, \mathrm{~T}_{\mathrm{amb}}=140^{\circ} \mathrm{F}\left(333.2^{\circ} \mathrm{K}\right)$ )

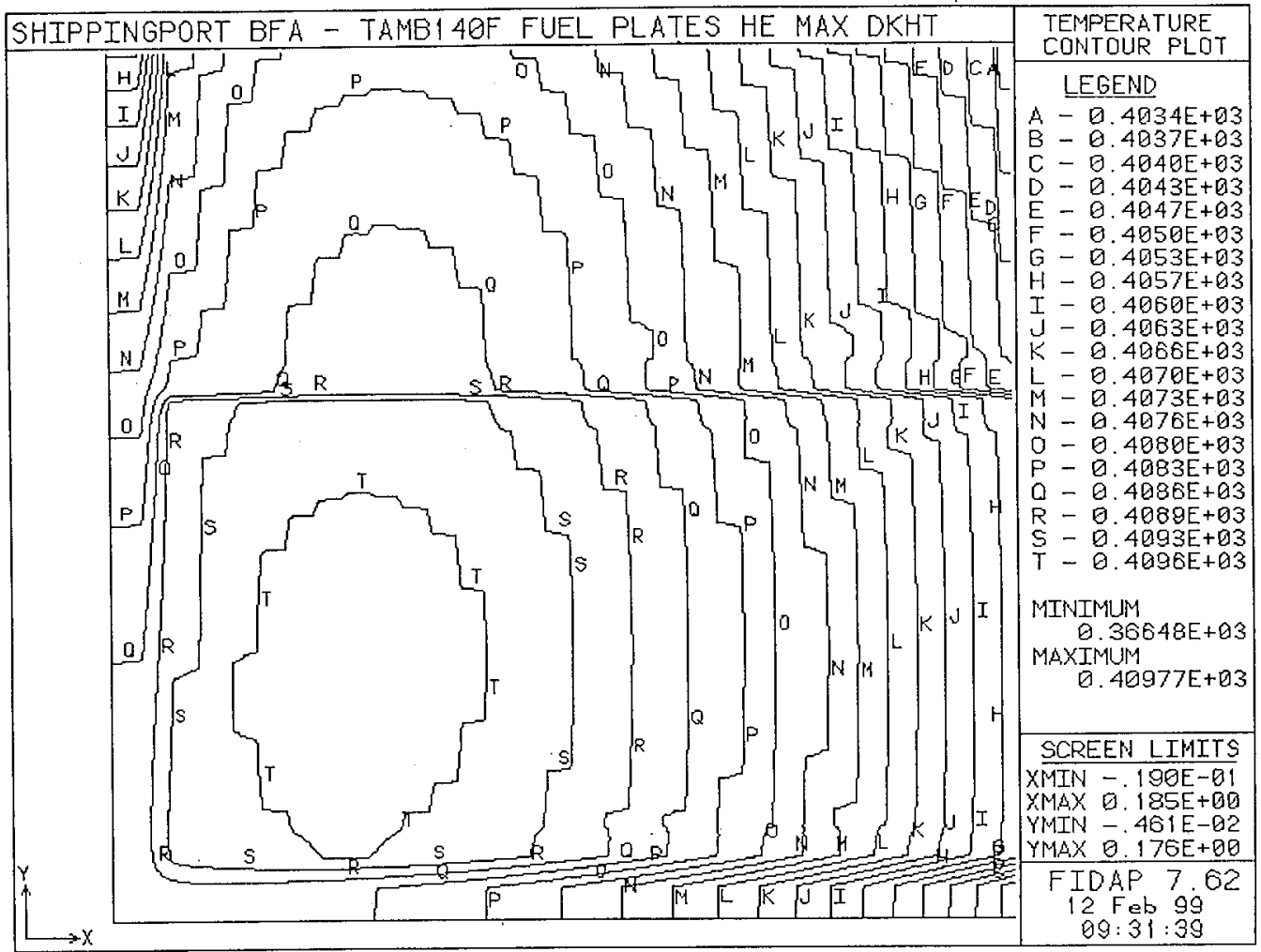


HNF-4109, Rev.0

Figure 5-5.

Coordinate Directions for Line Plots

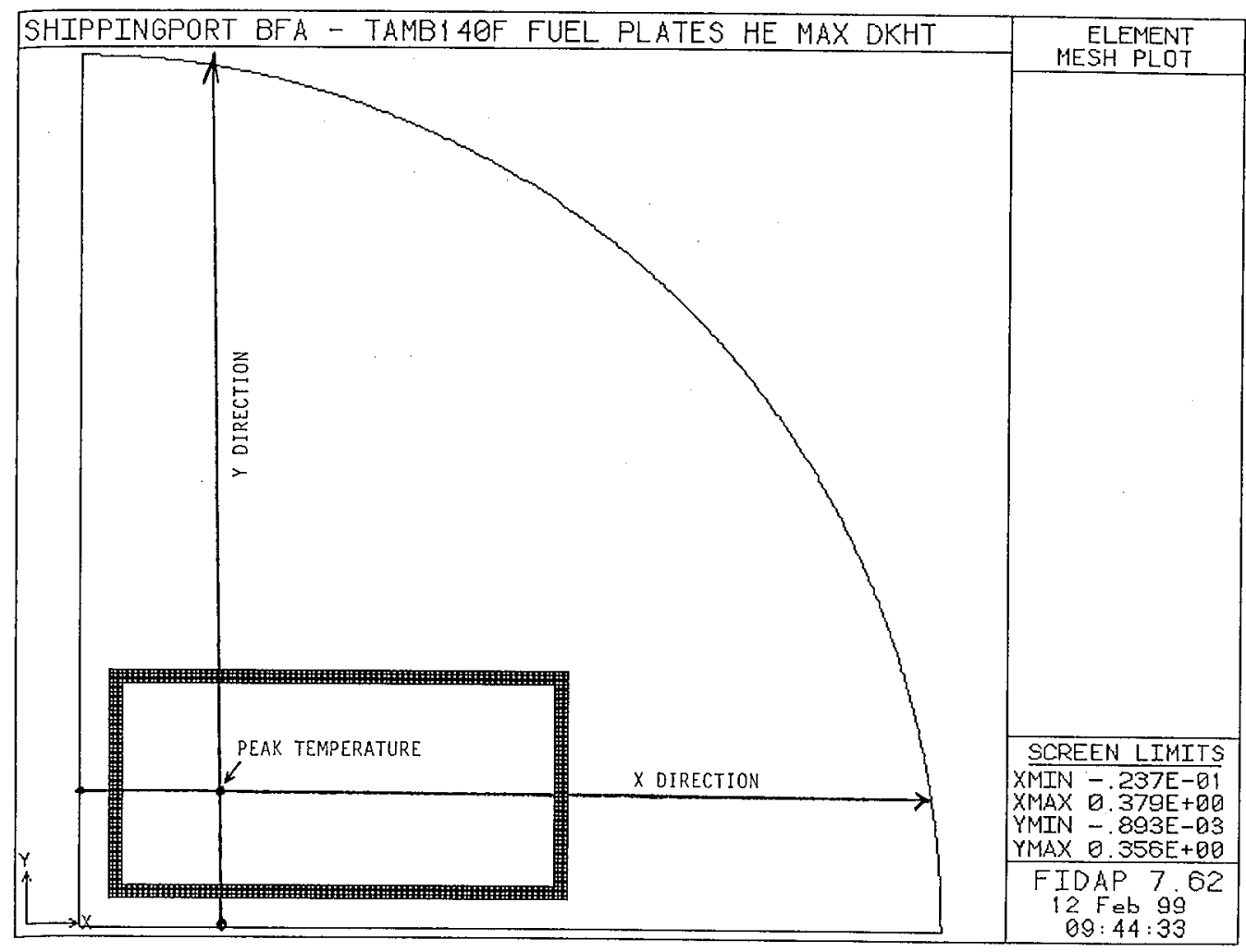


HNF-4109, Rev.0

Figure 5-6.

Temperature versus Horizontal Distance for Helium Backfill

Base Case BFA Thermal Model - Including Peak Temperature

$\left(\right.$ Decay Heat $=164.7$ Watts, $\mathrm{P} / \mathrm{A}=1.00, \mathrm{~T}_{\mathrm{amb}}=140^{\circ} \mathrm{F}\left(333.2^{\circ} \mathrm{K}\right)$ )

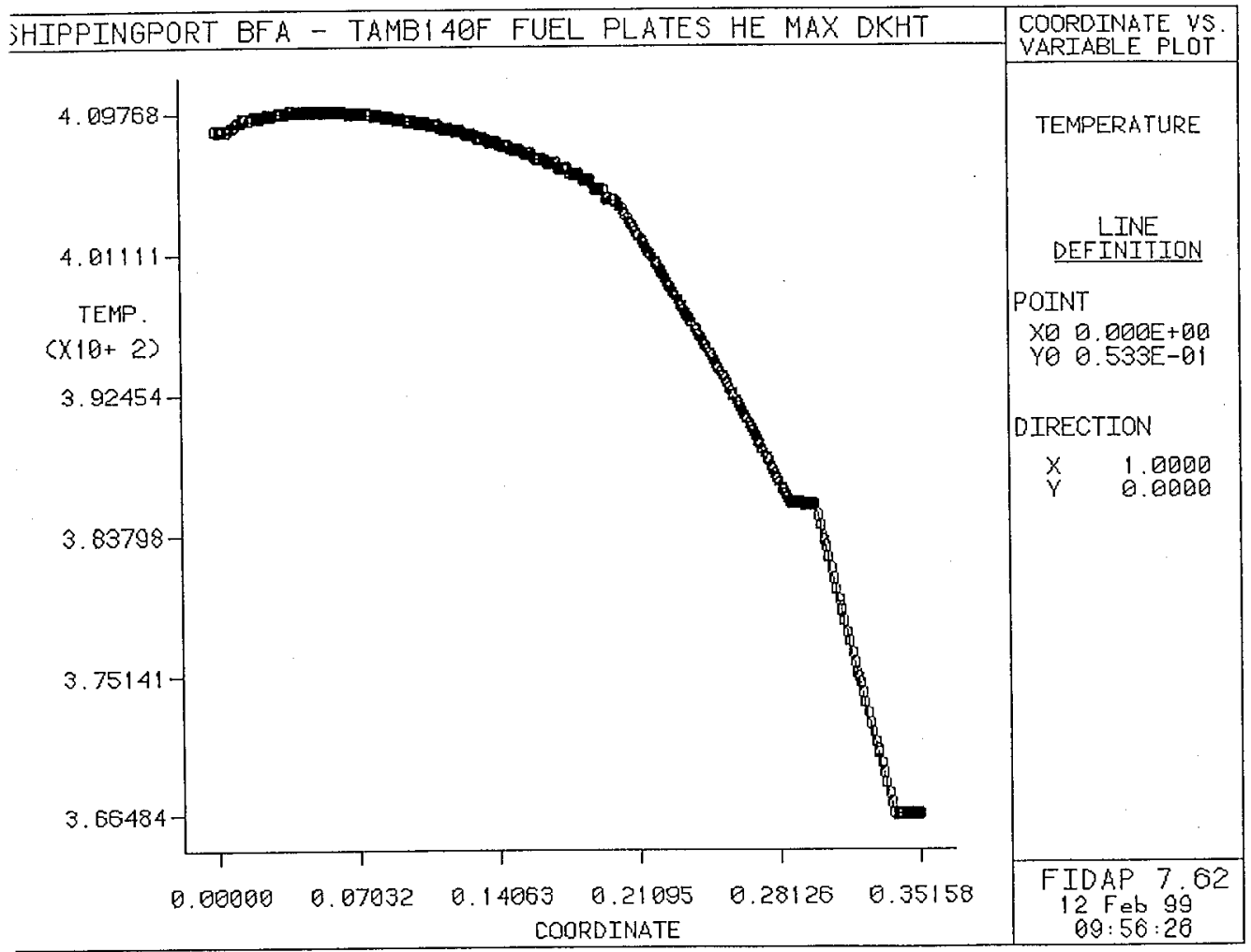


HNF-4109, Rev.0

Figure 5-7.

Temperature versus Vertical Distance for Helium Backfill

Base Case BFA Thermal Model - Including Peak Temperature

$\left(\right.$ Decay Heat $=164.7$ Watts, $\mathrm{P} / \mathrm{A}=1.00, \mathrm{~T}_{\mathrm{amb}}=140^{\circ} \mathrm{F}\left(333.2^{\circ} \mathrm{K}\right)$ )

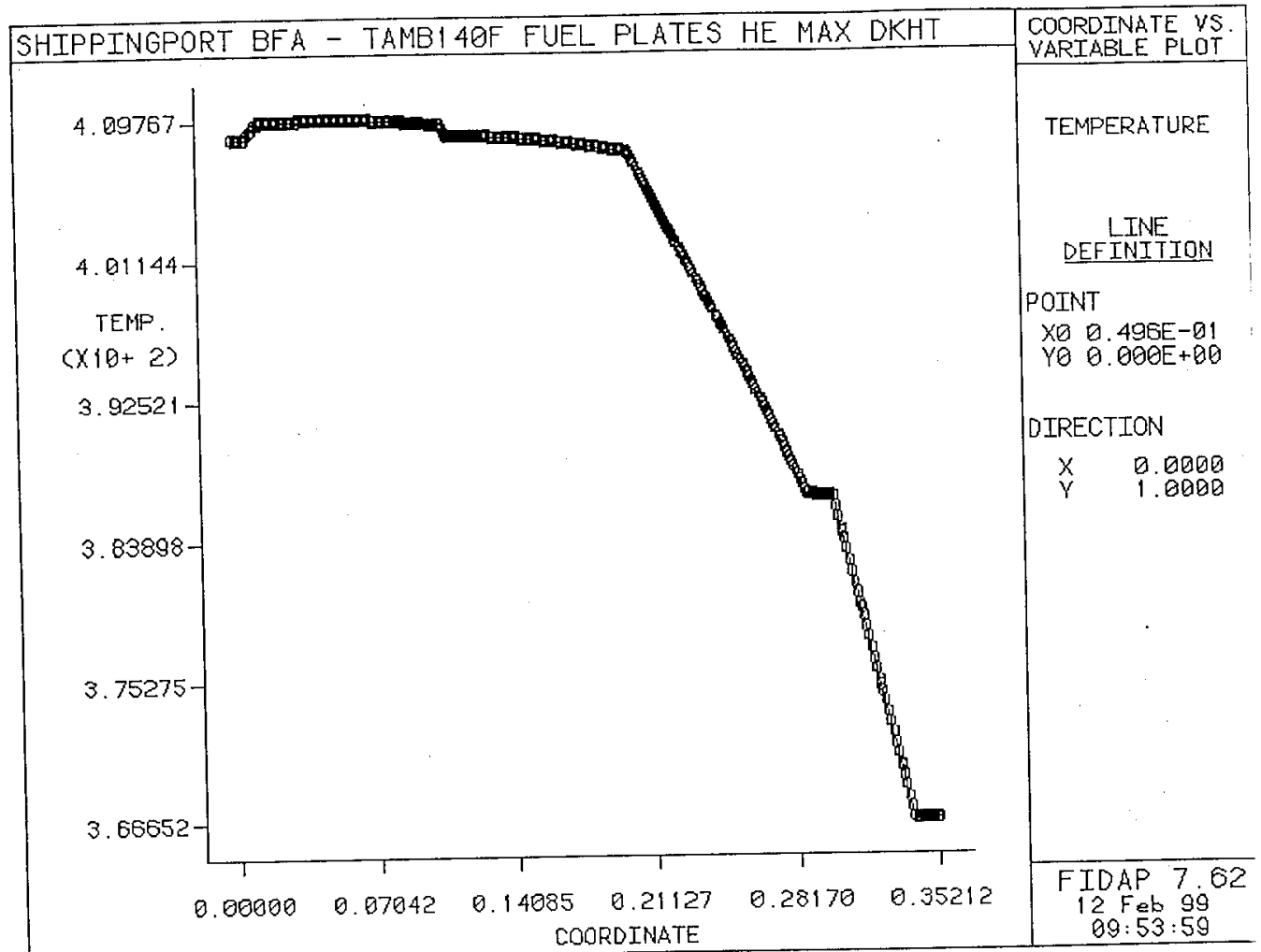


HNF-4109, Rev.0

Figure 5-8.

Temperature Contour Plot for Dry Air Backfill - Maximum Conditions

$\left(\right.$ Decay Heat $=164.7$ Watts, $\mathrm{P} / \mathrm{A}=1.55, \mathrm{~T}_{\text {amb }}=140^{\circ} \mathrm{F}\left(333.2^{\circ} \mathrm{K}\right)$ )

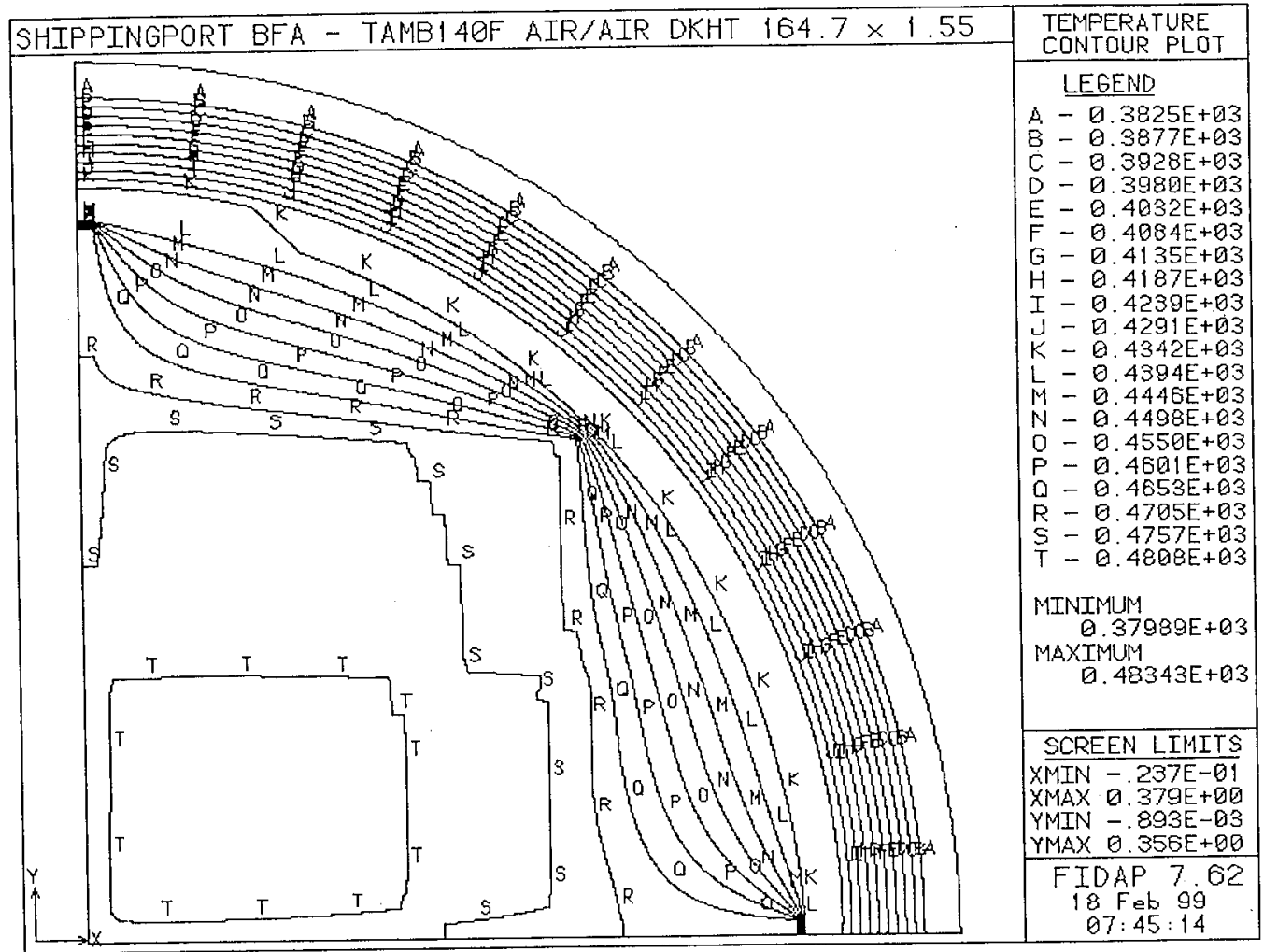


Figure 5-9.

Temperature Contour Plot for Dry Air Backfill - Minimum Conditions $\left(\right.$ Decay Heat $=93.39$ Watts, $\mathrm{P} / \mathrm{A}=1.00, \mathrm{~T}_{\mathrm{amb}}=110^{\circ} \mathrm{F}\left(316.5^{\circ} \mathrm{K}\right)$ )

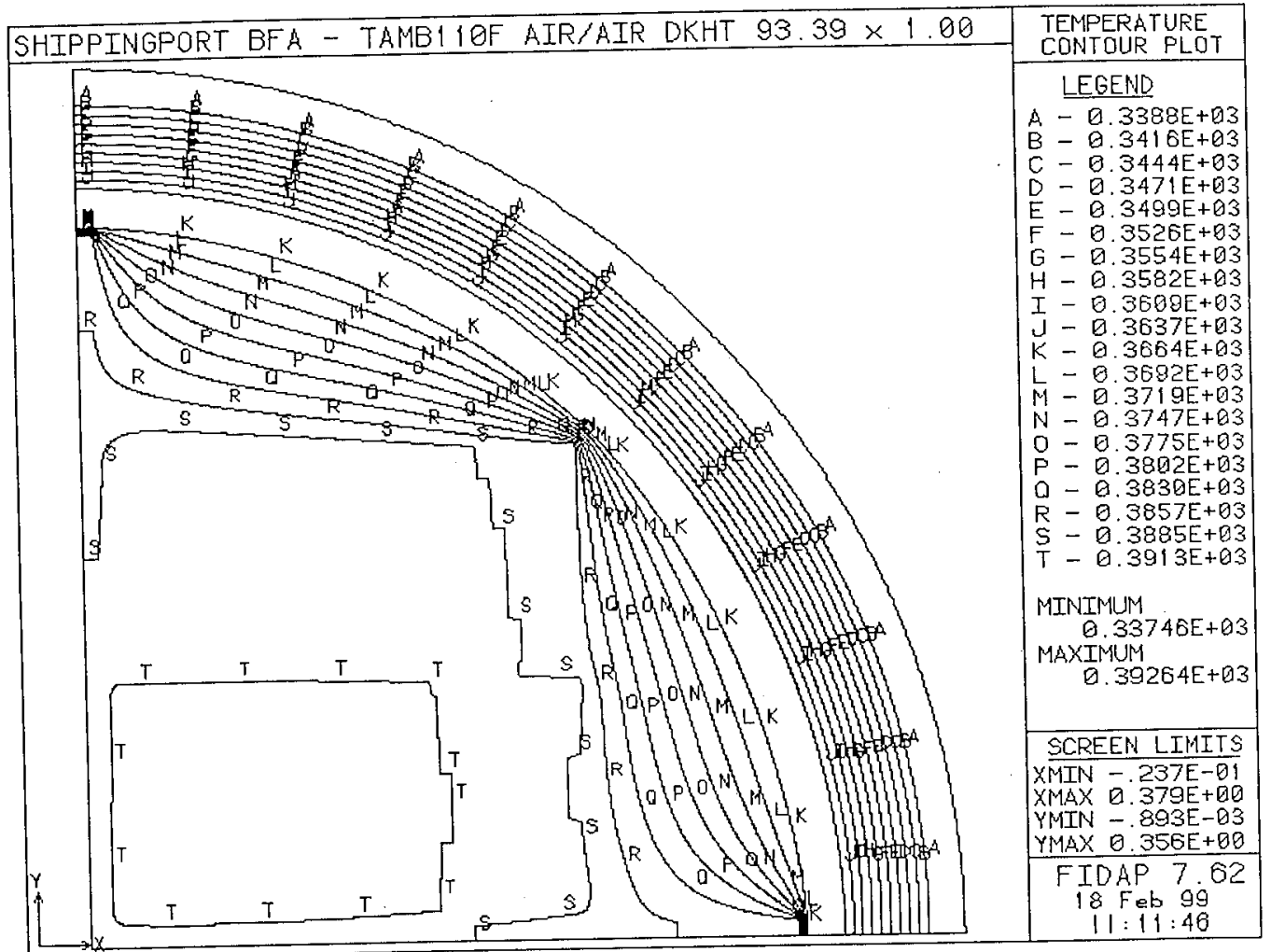


HNF-4109, Rev.0

Figure 5-10.

Temperature Contour Plot for Dry Air Backfill

Base Case Conditions

$\left(\right.$ Decay Heat $=164.7$ Watts, $\mathrm{P} / \mathrm{A}=1.00, \mathrm{~T}_{\mathrm{amb}}=140^{\circ} \mathrm{F}\left(333.2^{\circ} \mathrm{K}\right)$ )

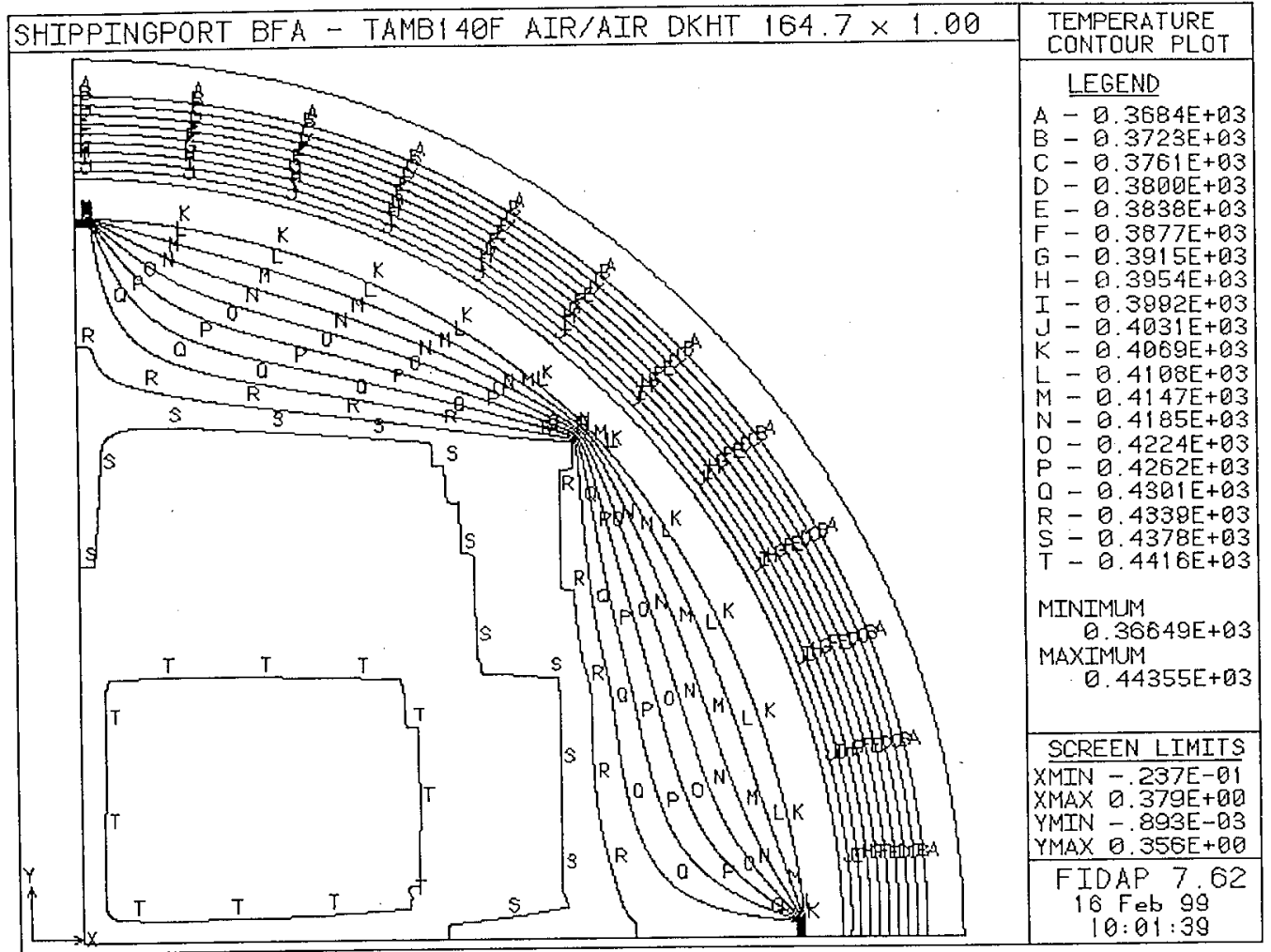


Figure 5-11.

Temperature Contour Plot for Dry Air Backfill - Base Case Conditions Near Center of MCO (Decay Heat $=164.7$ Watts, $\mathrm{P} / \mathrm{A}=1.00, \mathrm{~T}_{\mathrm{amb}}=140^{\circ} \mathrm{F}\left(333.2^{\circ} \mathrm{K}\right)$ )

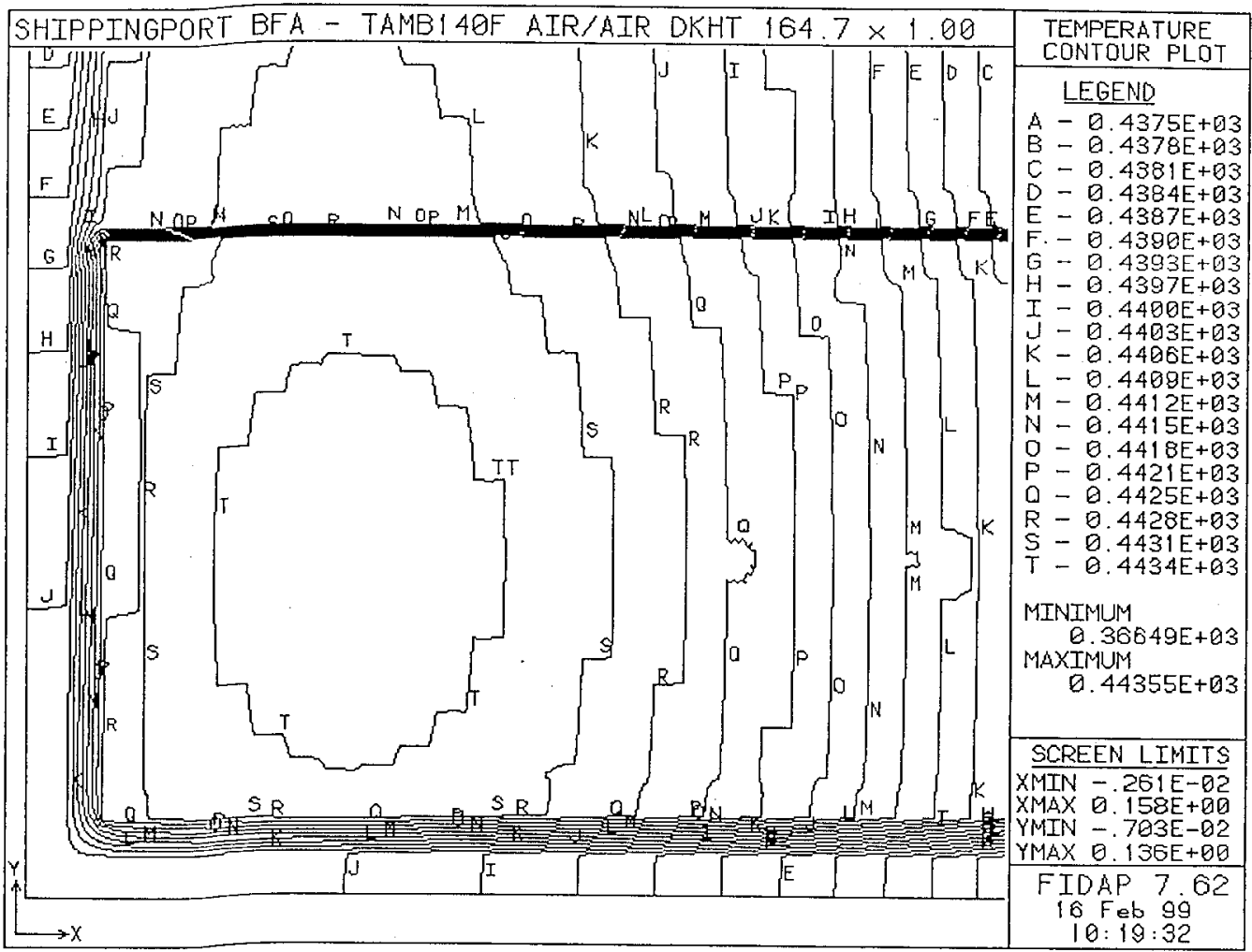




\subsection{CONCLUSIONS AND RECOMMENDATIONS}

Given one-fourth symmetry, a two-dimensional finite-element thermal model was developed of a MCO containing four Shippingport Blanket Fuel Assemblies (BFA) within a storage tube at the CSB. The thermal model contained enough detail to model the individual fuel plates; including each of the individual fuel wafers, cladding, and flow channels. The thermal model also modeled the surrounding blanket fuel sub-assembly cans, $\mathrm{MCO}$, and CSB storage tube.

The goal of the thermal analyses was to determine the peak cladding temperature for a range of decay heats and ambient vault conditions during nominal steady-state operations. The results of these analyses are expected to provide general guidance and support for the recommendation to transfer the spent Shippingport BFAs to the CSB.

The total assembly decay heat from a maximum exposure assembly was 164.70 Watts. Peak-toaverage $(\mathrm{P} / \mathrm{A})$ axial multipliers of 1.00 and 1.55 were used to derive the corresponding volumetric heat generation rate for input to the thermal model. (The peak-to-average multiplier of 1.55 is based on a representative cosine shape for the axial power distribution.) The peak ambient air temperature within the CSB vault ranged from $110^{\circ} \mathrm{F}\left(316.48^{\circ} \mathrm{K}\right)$ to $140^{\circ} \mathrm{F}$ $\left(333.15^{\circ} \mathrm{K}\right)$.

In each case, an energy balance was performed to confirm that the energy produced and removed from the energy model was in agreement with the values summarized in Table 4-3.

Seven conclusions are made and a single recommendation is offered in the last paragraph.

The conclusions are as follows:

1.) The maximum peak cladding temperature is $410.5^{\circ} \mathrm{F}\left(483.4^{\circ} \mathrm{K}\right)$, given maximum ( $\left.\mathrm{X} 1.55\right)$ decay heat, maximum CSB outlet temperature, and dry air (not helium) as the backfill gas within the $\mathrm{MCO}$ and CSB storage tube.

2.) The corresponding maximum (X 1.55) peak cladding temperature for a helium backfill within the MCO and CSB storage tube is $335.9^{\circ} \mathrm{F}\left(442.0^{\circ} \mathrm{K}\right)$.

3.) For minimum decay heat and CSB outlet temperature the peak cladding temperatures range from $197.9^{\circ} \mathrm{F}\left(365.3^{\circ} \mathrm{K}\right)$ to $247.1^{\circ} \mathrm{F}\left(392.6^{\circ} \mathrm{K}\right)$ for a helium and dry air filled MCO and CSB storage tube, respectively.

4.) Most of the temperature rise occurs over the large gaps between the MCO and CSB storage tube and the $\mathrm{MCO}$ and blanket fuel assembly.

5.) Very little temperature rise occurs within the blanket fuel assembly.

6.) Very good agreement was obtained between the results of the numerical simulations and a series of hand calculations. The greatest difference occurred when trying to estimate the temperature rise across the wedge shaped gap between the perimeter of the BFA and 
the ID of the MCO. Based on the agreement between the results of the hand calculations and the numerical simulation, the BFA thermal model was properly developed. Therefore, the results presented in Sections 5.1 and 5.2 are considered reasonable and representative of the expected temperatures for the given assumptions and conditions.

7.) The two-dimensional Blanket fuel Assembly thermal model is considered conservative. Some conservatism's are; no external radiation losses, no internal convective heat transport, and the simultaneous application of worst case conditions to a single storage tube. An additional conservatism, which continues to increase, is; the actual decay time after shutdown is greater than the 24 years assumed when deriving the total assembly decay heat.

8.) Uncertainties in the decay heat loads, geometry, and ambient storage vault conditions will affect peak cladding temperature. Because most of the temperature rise occurs over the various gaps, it is expected that the geometrical position of the blanket fuel assembly within the MCO will have the greatest affect on cladding temperatures

The following recommendation is offered:

Given the dimension of the MCO, the blanket fuel assemblies can rotate and/or tilt axially during transportation and handling. It is recommended that the spacer basket be modified to add small (two or three inches) projecting brackets just beyond the edge of each blanket assembly. These small brackets will help position the blanket fuel assemblies within the MCO canister consistent with the thermal analyses. 


\subsection{REFERENCES}

Carlson, A. B., "Evaluation of Other Spent Nuclear Fuel Management at the Canister Storage Building Complex," WHC-SD-SNF-TA-010, Westinghouse Hanford Company, Richland, Washington, dated November 1996.

Heard, F. J., "FIDAP - Validation and Verification," WHC-SD-WM-ER-302, Rev. 1, Westinghouse Hanford Company, Richland, Washington, dated 1994.

Holman, J. P., "Heat Transfer," Seventh Edition, McGraw-Hill, Inc., New York, New York, 1990.

Lorenz, B. D., "Multi-Canister Overpack Topical Report," HNF-SD-SNF-SARR-005, Rev. 0, Duke Engineering and Services Hanford, Richland, Washington, dated March 26, 1997.

Wittekind, W. D., "Shippingport Pressurized Water Reactor Core 2 Blanket Assemblies Source Term Calculations Using ORIGEN2," HNF-SD-SNF-TI-061, Rev. 0, Fluor Daniel Northwest, Inc., Richland, Washington, dated November 5, 1997.

Wittekind, W. D. "Shippingport Pressurized Water Reactor Core 2 Blanket Assemblies in Multi-Canister Overpack Shielding Calculations Using MCNP," HNF-SD-SNFTI-062, Rev. 0, Fluor Daniel Northwest, Inc., Richland, Washington, dated March 23, 1998. 
HNF-4109, Rev.0

\section{Appendix A}

Representative Input for BFA Thermal Model 
$\mathrm{BEDG}=1, \mathrm{SPAV}=1, \mathrm{MSHE}=1, \mathrm{MSOL}=1, \mathrm{COOR}=1, \mathrm{TOL} E=\$$ tole $)$

UTILITY (MESH, LIVE)

WINDOW (CHANGE $=1$, MATRIX)

$\begin{array}{rrrr}1.000000 & 0.000000 & 0.000000 & 0.000000 \\ 0.000000 & 1.000000 & 0.000000 & 0.000000 \\ 0.000000 & 0.000000 & 1.000000 & 0.000000 \\ 0.000000 & 0.000000 & 0.000000 & 1.000000 \\ -4.05375 & 15.54625 & -0.35000 & 14.35000 \\ 45.000000 & 45.000000 & 45.000000 & 45.000000\end{array}$

/ $2 D$ XY MODEL - QUARTER SYMMETRY

, ZERO FLUX BOUNDARIES - X AND Y AXES

$/$ DECAY HEAT $=164.7 \mathrm{~W}$

/ RATIO OF PFAK-TO-AVERAGE DECAY HEAT $=1.55$

/ FILL GAS - INTERNAL MCO = AIR

/ FILL GAS - MCO STUBE GAP = AIR

$/$ AMBIENT TEMPERATATURE $=140 \mathrm{~F}=60.00 \mathrm{C}=333.15 \mathrm{~K}$

/ SEPARATE FLOW CHANNELS

/ SEPARATE CLAD + RIBBING

SEPARATE FUEL SEGMENTS

NONISOTROPIC THERMAL CONDUCTIVITY TO ACCOUNT FOR DELTA X VARIATIONS

/ "HE2X" - END CHANNELS KMODEL = KACTUAL X 0.6995

1 "HE3X" - INTERIOR CHANNELS

"AIR2X" - END CHANNELS

KMODEL = KACTUAL $\times 0.5073$

"AIR3X" - INTERIOR CHANNELS

KMODEL = KACTUAL X 0.6995

KMODEL = KACTUAL X 0.5073

"ZIRC2X" - CLADDING AND RIBBING KMODEL = KACTUAL X 1.3191

"UO2X" - FUEL

KMODEL = KACTUAL $X 0.9233$

NODAL STRUCTURE

EDGE NODES $=2$

QUAD NODES $=4$

INPUT FILE $=$ hnE4109.inp

METRIC UNITS USED - EXCEPT INPUT DIMENSIONS WHICH USE INCHES

INCHES CONVERTED TO METERS VIA FIPREP SCALE FACTOR

METERS, KILOGRAMS, SECONDS, AND KELVIN

BASIC GEOMETRY - CENTRAL CROSS

GAP1, GAP2, AND GAP3

BLANKET FUEI ASSEMBLY (FLOW+CLAD+FUEL)

INTER-ASSEMBLY GAP

BLANKET FUEL ASSEMBIY (FLOW+CIAD+FUEL)

INTERNAL MCO FLOW REGIONS

MCO WALL

GAP BETWEEN MCO AND ST (E:=0.01)

STORAGE TUBE (ST) WALL

$\$ D X=0.25$

$\$ D Y=0.25$

1

$/$ POINTS $1-19$

POINT (ADD, SHOW, COOR, $X=0.0, Y=0.0$ )

POINT (ADD, SHOW, COOR, $X=0.0, Y=0.25$ )

POINT (ADD, SHOW, COOR, $X=0.0, Y=0.25+\$ D Y$ )

POINT (ADD, SHOW, COOR, $X=0.0, Y=0.25+\$ D Y+0.20$ )

POINT (ADD, SHOW, COOR, $X=0.0, Y=0.25+\$ D Y+0.20+0.25$ )

POINT (ADD, SHOW, COOR, $X=0.0, Y=0.25+\$ D Y+0.20+0.25+2.75$ )

POINT (ADD, SHOW, COOR, $X=0.0, Y=0.25+\$ D Y+0.20+0.25+2.75+0.25$ )

POINT (ADD, SHOW, COOR, $X=0.0, Y=0.25+\$ D Y+0.20+0.25+2.75+0.25+0.20$ ) 
POINT ( $A D D, S H O W, C O O R, X=0.0, Y=0.25+\$ D Y+3.65+0.0855$ )

POINT (ADD, SHOW, COOR, $X=0.0, Y=0.25+\$ D Y+3.65+0.0855+0.20$ )

POINT (ADD, SHOW, COOR, $X=0.0, Y=0.25+\$ D Y+3.65+0.0855+0.20+0.25$ )

POINT (ADD, SHOW, COOR, $X=0.0, Y=0.25+\$ D Y+3.65+0.0855+0.20+0.25+2.75$ )

POINT (ADD, SHOW, COOR, $X=0.0, Y=0.25+\$ D Y+3.65+0.0855+0.20+0.25+2.75+0.25$ )

POINT (ADD, SHOW, COOR, $X=0.0, Y=0.25+\$ D Y+3.65+0.0855+0.20+0.25+2.75+0.25+0.20$ )

POINT ( $A D D$, SHOW, COOR, $X=0.0, Y=11.3675$ )

POINT ( $A D D$, SHOW, COOR, $X=0.0, Y=11.4925$ )

POINT (ADD, SHOW, COOR, $X=0.0, Y=11.9925$ )

POINT (ADD, SHOW, COOR, $X=0.0, Y=13.5$ )

POINT ( ADD, SHOW, COOR, $X=0.0, Y=14.0$ )

r

1 POINTS $20-38$

,

POINT (ADD, SHOW, COOR, $X=0.25, Y=0.0$ )

POINT (ADD, SHOW, COOR, $X=0.25, Y=0.25$ )

POINT (ADD, SHOW, COOR, $X=0.25, Y=0.25+\$ D Y$ )

POINT (ADD, SHOW, COOR, $X=0.25, Y=0.25+\$ D Y+0.20$ )

POINT (ADD, SHOW, COOR, $X=0.25, Y=0.25+\$ D Y+0.20+0.25$ )

POINT (ADD, SHOW, COOR, $X=0.25, Y=0.25+\$ D Y+0.20+0.25+2.75$ )

POINT (ADD, SHOW, COOR, $X=0.25, Y=0.25+\$ D Y+0.20+0.25+2.75+0.25$ )

POINT (ADD, SHOW, COOR, $X=0.25, Y=0.25+\$ D Y+0.20+0.25+2.75+0.25+0.20$ )

POINT (ADD, SHOW, COOR, $X=0.25, Y=0.25+\$ D Y+3.65+0.0855$ )

POINT (ADD, SHOW, COOR, $X=0.25, Y=0.25+\$ D Y+3.65+0.0855+0.20$ )

POINT (ADD, SHOW, COOR, $X=0.25, Y=0.25+\$ D Y+3.65+0.0855+0.20+0.25$ )

POINT (ADD, SHOW, COOR, $X=0.25, Y=0.25+\$ D Y+3.65+0.0855+0.20+0.25+2.75$ )

POINT (ADD, SHOW, COOR, $X=0.25, Y=0.25+\$ D Y+3.65+0.0855+0.20+0.25+2.75+0.25$ )

POINT (ADD, SHOW, COOR, $X=0.25, Y=0.25+\$ D Y+3.65+0.0855+0.20+0.25+2.75+0.25+0.20$ )

POINT ( $A D D$, SHOW, COOR, $X=0.25, Y=11.3675$ )

POINT ( $A D D$, SHOW, COOR, $X=0.25, Y=11.4897818$ )

POINT (ADD, SHOW, COOR, $X=0.25, Y=11.98989505$ )

POINT (ADD, SHOW, COOR, $X=0.25, Y=13.49768578$ )

POINT (ADD, SHOW, COOR, $X=0.25, Y=13.99776839$ )

1

/ POINTS $39-42$

,

POINT (ADD, SHOW, COOR, $X=8.126424683, Y=8.126424683$ )

POINT (ADD, SHOW, COOR, $X=8.479978073, Y=8.479978073$ )

POINT (ADD, SHOW, COOR, $X=9.545941546, Y=9.545941546$ )

POINT (ADD, SHOW, COOR, $X=9.899494937, Y=9.899494937$ )

I

$/$ POINTS $43-60$

/

POINT ( ADD, SHOW, COOR, $X=0.25+\$ D X, Y=0.0$ )

POINT (ADD, SHOW, COOR, $X=0.25+\$ D X, Y=0.25$ )

POINT (ADD, SHOW, COOR, $X=0.25+\$ D X+0.20725, Y=0.0$ )

POINT ( $A D D$, SHOW, COOR, $X=0.25+\$ D X+0.20725, Y=0.25$ )

POINT (ADD, SHOW, COOR, $X=11.3675, Y=0.0$ )

POINT ( $A D D$, SHOW, COOR, $X=11.3675, Y=0.25$ )

POINT ( ADD, SHOW, COOR, $X=11.4925, Y=0.0$ )

POINT ( $A D D$, SHOW, COOR, $X=11.4897818, Y=0.25$ )

POINT ( $A D D$, SHOW, COOR, $X=11.9925, Y=0.0$ )

POINT (ADD, SHOW, COOR, $X=11.98989505, Y=0.25$ )

POINT ( $A D D$, SHOW, COOR, $X=13.5, Y=0.0$ )

POINT (ADD, SHOW, COOR, $X=13.49768578, Y=0.25$ )

POINT (ADD, SHOW, COOR, $X=14.0, Y=0.0$ )

POINT (ADD, SHOW, COOR, $X=13.99776839, Y=0.25$ )

POINT (ADD, SHOW, COOR, $X=0.25+\$ D X+0.20725+6.971, Y=0.0$ )

POINT (ADD, SHOW, COOR, $X=0.25+\$ D X+0.20725+6.971, Y=0.25$ )

POINT ( $A D D$, SHOW, COOR, $X=0.25+\$ D X+0.20725+5.971+0.20725, Y=0.0$ )

POINT (ADD, SHOW, COOR, $X=0.25+\$ D X+0.20725+6.971+0.20725, Y=0.25$ )

I

/ CONNECT DOT-TO-DOT (I.E. POINTS) TO FORM CURVES

1

$/$ CURVE \#1 
CURVE (ADD, SHOW, ARROW, ORDER=1)

POINT (SELE, ID, WIND=1)

20

21

CURVE (ADD, SHOW, ARROW, ORDER=1)

POINT (SELE, ID, WIND $=1$ )

21

2

CURVE (ADD, SHOW, ARROW, ORDER=1)

POINT (SELE, ID, WIND=1)

2

1

CURVE (ADD, SHOW, ARROW, ORDER=1)

/

, CURVE \#5

1

POINT (SELE, ID, WIND=1)

21

22

CURVE (ADD, SHOW, ARROW, ORDER=1)

POINT ( SELE, ID, WIND=1)

22

23

CURVE (ADD, SHOW, ARROW, ORDER=1)

POINT (SELE, ID, WIND=1)

23

24

CURVE (ADD, SHOW, ARROW, ORDER=1)

POINT (SELE, ID, WIND=1)

24

25

CURVE (ADD, SHOW, ARROW, ORDER=1)

POINT (SELE, ID, WIND $=1$ )

25

26

CURVE (ADD, SHOW, ARROW, ORDER=1)

/

/ CURVE \#10

1

POINT (SELE, ID, WIND=1)

26

27

CURVE (ADD, SHOW, ARROW, ORDER=1)

POINT ( SELE, ID, WIND=1)

27

28

CURVE (ADD, SHOW, ARROW, ORDER=1)

POINT (SELE, ID, WIND=1)

28

29

CURVE (ADD, SHOW, ARROW, ORDER=1)

POINT (SELE, ID, WIND=1)

29

30

CURVE (ADD, SHOW, ARROW, ORDER=1)

POINT (SELE, ID, WIND=1)

30

31

CURVE (ADD, SHOW, ARROW, ORDER=1)

I

$/$ CURVE \#15

1

POINT $\{$ SELE, ID, WIND=1) 
4

3

CURVE (ADD, SHOW, ARROW, ORDER=1)

POINT ( $S E L E, ~ I D, W I N D=1$ )

3

2.

CURVE (ADD, SHOW, ARROW, ORDER=1)

POINT ( SELE, ID, WIND=1)

34

35

CURVE (ADD, SHOW, ARROW, ORDER=1)

POINT (SELE, ID, WIND =1)

35

16

CURVE (ADD, SHOW, ARROW, ORDER=1)

POINT (SEIE, ID, WIND=1)

16

15

CURVE (ADD, SHOW, ARROW, ORDER=1)

1 .

/ CURVE \#35

I

POINT (SELE, ID, WIND=1)

1

35

39

CURVE (ADD, ARC, SHOW, ARROW, CENT)

POINT (SELE, ID, WIND=1)

1

39

50

CURVE (ADD, ARC, SHOW, ARROW, CENT)

POINT (SEIE, ID, WIND=1)

50

49

CURVE (ADD, SHOW, ARROW, ORDER=1)

POINT (SELE, ID, WIND=1)

49

51

CURVE (ADD, SHOW, ARROW, ORDER=1)

POINT (SELE, ID, WIND =1)

51

52

CURVE (ADD, SHOW, ARROW, ORDER=1)

I

CURVE \#40

1

POINT (SELE, ID, WIND=1)

1

52

40

CURVE (ADD, ARC, SHOW, ARROW, CENT)

POINT ( SELE, ID, WIND=1)

1

40

36

CURVE (ADD, ARC, SHOW, ARROW, CENT)

POINT (SELE, ID, WIND=1)

36

17

CURVE (ADD, SHOW, ARROW, ORDER=1)

POINT (SELE, ID, WIND=1)

17 
18

CURVE (ADD, SHOW, ARROW, ORDER=1)

,

/ CURVE \#45

/

POINT ( SELE, ID, WIND =1)

18

37

CURVE (ADD, SHOW, ARROW, ORDER=1)

POINT ( SELE, ID, WIND $=1$ )

1

37

41

CURVE (ADD, ARC, SHOW, ARROW, CENT)

POINT (SELE, ID, WIND =1)

1

41

54

CURVE (ADD, ARC, SHOW, ARROW, CENT)

POINT ( SELE, ID, WIND =1)

54

53

CURVE (ADD, SHOW, ARROW, ORDER=1)

POINT ( SELE, ID, WIND $=1$ )

51

53

CURVE (ADD, SHOW, ARROW, ORDER=1)

I

$/$ CURVE \#50

1

POINT (SELE, ID, WIND=1)

53

55

CURVE ( $A D D, S H O W$, ARROW, ORDER=1)

POINT ( SELE, ID, WIND=1)

55

56

CURVE ( $A D D$, SHOW, ARROW, ORDER=1)

POINT (SELE, ID, WIND=1)

1

56

42

CURVE (ADD, ARC, SHOW, ARROW, CENT)

POINT (SELE, ID, WIND $=1$ )

1

42

38

CURVE (ADD, ARC, SHOW, ARROW, CENT)

POINT (SELE, ID, WIND $=1$ )

38

19

CURVE (ADD, SHOW, ARROW, ORDER=1)

,

/ CURVE \#55

/

POINT (SELE, ID, WIND=1)

19

18

CURVE (ADD, SHOW, ARROW, ORDER=1)

POINT (SELE, ID, WIND =1)

50

48 
47

CURVE (ADD, SHOW, ARROW, ORDER=1)

POINT (SELE, ID, WIND=I)

47

49

CURVE (ADD, SHOW, ARROW, ORDER=1)

POINT (SELE, ID, WIND=1)

20

43

CURVE (ADD, SHOW, ARROW, ORDER=1)

1

/ CURVE \#60

1

POINT (SELE, ID, WIND=1)

21

44

CURVE (ADD, SHOW, ARROW, ORDER=1)

POINT (SELE, ID, WIND=1)

59

47

CURVE (ADD, SHOW, ARROW, ORDER=1)

POINT (SELE, ID, WIND=1)

60

48

CURVE (ADD, SHOW, ARROW, ORDER=1)

POINT (SELE, ID, WIND=1)

43

45

CURVE (ADD, SHOW, ARROW, ORDER=1)

POINT ( $S E L E$, ID, WIND=1)

44

46

CURVE (ADD, SHOW, ARROW, ORDER=1)

1

/ CURVE \#65

1

POINT (SELE, ID, WIND=1)

45

57

CURVE (ADD, SHOW, ARROW, ORDER=1)

POINT (SELE, ID, WIND=1)

46

58

CURVE (ADD, SHOW, ARROW, ORDER=1)

POINT (SELE, ID, WIND=1)

57

59

CURVE (ADD, SHOW, ARROW, ORDER=1)

POINT (SELE, ID, WIND =1)

58

60

CURVE (ADD, SHOW, ARROW, ORDER=1)

/

/ SURFACE

1

CURVE (SELECT, ID, WIND=1)

1 
4

SURFACE (ADD, WIRE, SHOW, EDG1=10, $\mathrm{EDG} 2=2, \mathrm{EDG} 3=2, \mathrm{EDG} 4=18$ ) I MACRO ( name $=$ "half")

1 / argument 6 increments entity names for given fuel assembly numbers 1 
POINT (ADD, SHOW, COOR, $Y=0.0, X=0.20725+6.971$ )

POINT (ADD, SHOW, COOR, $Y=0.0, X=0.20725+6.971+0.20725$ )

1

1 POINTS $65-68$ and POINTS $89-92$

POINT (ADD, SHOW, COOR, $Y=0.20, X=0.0$ )

POINT (ADD, SHOW, COOR, $Y=0.20, X=0.20725$ )

POINT (ADD, SHOW, COOR, $Y=0.20, X=0.20725+6.971$ )

POINT (ADD, SHOW, COOR, $Y=0.20, X=0.20725+6.971+0.20725)$

I

/

,

POINT (ADD, SHOW, COOR, $Y=0.20+0.25, X=0.0$ )

POINT (ADD, SHOW, COOR, $Y=0.20+0.25, X=0.20725$ )

POINT (ADD, SHOW, COOR, $Y=0.20+0.25, X=0.20725+6.971$ )

POINT (ADD, SHOW, COOR, $Y=0.20+0.25, X=0.20725+6.971+0.20725$ )

1

POINTS $73-76$ and POINTS 97 - 100

POINT (ADD, SHOW, COOR, $Y=0.20+0.25+2.75, X=0.0$ )

POINT (ADD, SHOW, COOR, $Y=0.20+0.25+2.75, X=0.20725$ )

POINT (ADD, SHOW, COOR, $Y=0.20+0.25+2.75, X=0.20725+6.971$ )

POINT (ADD, SHOW, COOR, $Y=0.20+0.25+2.75, X=0.20725+6.971+0.20725$ )

1

$/$ POINTS 77 - 80 and POINTS $101-104$

POINT (ADD, SHOW, COOR, $Y=0.20+0.25+2.75+0.25, X=0.0$ )

POINT (ADD, SHOW, COOR, $Y=0.20+0.25+2.75+0.25, X=0.20725$ )

POINT (ADD, SHOW, COOR, $Y=0.20+0.25+2.75+0.25, X=0.20725+6.971$ )

POINT (ADD, SHOW, COOR, $Y=0.20+0.25+2.75+0.25, X=0.20725+6.971+0.20725$ )

1

$/$ POINTS $81-84$ and POINTS $105-108$

POINT (ADD, SHOW, COOR, $Y=0.20+0.25+2.75+0.25+0.20, X=0.0)$

POINT (ADD, SHOW, COOR, $Y=0.20+0.25+2.75+0.25+0.20, X=0.20725$ )

POINT (ADD, SHOW, COOR, $Y=0.20+0.25+2.75+0.25+0.20, X=0.20725+6.971$ )

POINT (ADD, SHOW, COOR, $Y=0.20+0.25+2.75+0.25+0.20, X=0.20725+6.971+0.20725$ )

1

CURVES

POINT (SELECT, ID, WINDOW=1)

(\$POI + 1$)$

$(\$ P O I+2)$

CURVE (ADD, SHOW, ARROW, ORDER=1)

POINT (SELECT, ID, WINDOW=1)

$(\$ P O I+2)$

$(\$ P O I+3)$

CURVE (ADD, SHOW, ARROW, ORDER=1)

POINT (SELECT, ID, WINDOW=1)

$(\$ P O I+3)$

$(\$ P O I+4)$

CURVE (ADD, SHOW, ARROW, ORDER=1)

POINT (SELECT, ID, WINDOW $=1$ )

(\$POI + 4)

$(S P O I+8)$

CURVE (ADD, SHOW, ARROW, ORDER=1)

POINT (SELECT, ID, WINDOW=1)

(\$POI + 8)

(SPOI + 12)

CURVE (ADD, SHOW, ARROW, ORDER=1)

POINT (SELECT, ID, WINDOW=1)

$(\$ \mathrm{POI}+12)$

(\$POI + 16)

CURVE (ADD, SHOW, ARROW, ORDER =1)

POINT (SELECT, ID, WINDOW=1)

$(\$ P O I+16)$
HNF-4109, Rev. 0

Appendix A 
(\$POI + 20)

$(\$ P O I+24)$

CURVE (ADD, SHOW, ARROW, ORDER=1)

POINT (SELECT, ID, WINDOW=1)

$(\$ P O I+24)$

(\$POI + 23)

CURVE (ADD , SHOW, ARROW, ORDER=1)

POINT (SELECT, ID, WINDOW=1)

$(S P O I+23)$

(SPOI + 22)

CURVE (ADD, SHOW, ARROW, ORDER=1)

POINT (SELECT, ID, WINDOW $=1$ )

$(S P O I+22)$

(SPOI + 21)

CURVE (ADD, SHOW, ARROW, ORDER=1)

POINT (SELECT, ID, WINDOW=1)

$(\$ P O I+21)$

$(\$ P O I+17)$

CURVE (ADD, SHOW, ARROW, ORDER=1)

POINT (SELECT, ID, WINDOW=1)

$(S P O I+17)$

(\$POI + 13)

CURVE (ADD, SHOW, ARROW, ORDER=1)

POINT (SELECT, ID, WINDOW=1)

$(\$ P O I+13)$

$(\$ P O I+9)$

CURVE (ADD, SHOW, ARROW, ORDER=1)

POINT (SELECT, ID, WINDOW=1)

$(\$ \mathrm{POI}+9)$

$(\$ P O I+5)$

CURVE (ADD, SHOW, ARROW, ORDER=1)

POINT (SELECT, ID, WINDOW=1)

$(\$ P O I+5)$

$(S P O I+1)$

CURVE (ADD, SHOW, ARROW, ORDER=1)

POINT (SELECT, ID, WINDOW $=1$ )

(\$POI + 6)

$(\$ P O I+7)$

CURVE (ADD, SHOW, ARROW, ORDER=1)

POINT (SELECT, ID, WINDOW $=1$ )

$(\$ P O I+7)$

(SPOI + 11)

CURVE (ADD, SHOW, ARROW, ORDER=1)

POINT (SELECT, ID, WINDOW=1)

$(\$ P O I+11)$

(\$POI + 15)

CURVE (ADD, SHOW, ARROW, ORDER=1)

POINT (SELECT , ID, WINDOW=1)

(\$POI + 15)

(\$POI + 19)

CURVE (ADD, SHOW, ARROW, ORDER=1)

POINT (SELECT, ID, WINDOW=1)

(\$POI + 19)

(\$POI + 18)

CURVE (ADD, SHOW, ARROW, ORDER=1)

POINT (SEIECT, ID, WINDOW=1)

$(\$ P O I+18)$

$(\$ P O I+14)$

CURVE (ADD, SHOW, ARROW, ORDER=1)

POINT (SELECT, ID, WINDOW=1)

$(\$ \mathrm{POI}+14)$

(\$POI + 10)

CURVE (ADD, SHOW, ARROW, ORDER=1) 
I

COORDINATE ( SELE, ID $=1$ )

COORDINATE ( ACTIVE)

ENDMACRO

$$
\text { I }
$$

$\$ x 10 c=0.25+\$ D X$

\$Yloc $=0.25+\$ D Y$

$\$ z 10 C=0$

\$axis $=3$

\$angl $=0.0$

ssysid $=2$

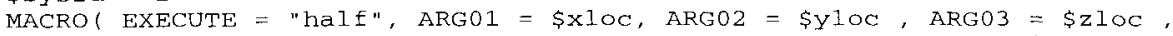
ARG04 = \$axis, $\operatorname{ARG05}=$ \$angl, $\operatorname{ARG06}=1, \operatorname{ARG07}=$ \$sysid)

I

$\$ \mathrm{x} 10 \mathrm{C}=0.25+\$ \mathrm{DX}$

$\$ y l o c=0.25+\$ D Y+3.65+0.0855$

$\$ z l o c=0$

Saxis= 3

$\$ \operatorname{ang} 1=0.0$

$\$$ sysid $=3$

MACRO( EXECUTE $=$ "half", ARGO1 =\$Xloc, ARG02 =\$Y1OC, ARGO3=\$zloc, ARG04 = \$axis, $A$ RG05 = \$angl, $A$ RG06 $=2$, ARG07 = \$sysid)

/

,

'

Define the remaining geometry and mesh beginning here

/

UTILITY (MESH, LIVE)

1

/ Insert global WINDOW command here for first part of construction

$/$

WINDOW (CHANGE $=1$, MATRIX)

$\begin{array}{llll}1.000000 & 0.000000 & 0.000000 & 0.000000\end{array}$

$0.000000 \quad 1.000000 \quad 0.000000 \quad 0.000000$

$0.000000 \quad 0.000000 \quad 1.000000 \quad 0.000000$

$0.000000 \quad 0.000000 \quad 0.000000 \quad 1.000000$

$\begin{array}{llll}-4.05375 & 15.54625 & -0.35000 & 14.35000\end{array}$

$\begin{array}{lll}45.000000 \quad 45.000000 & 45.000000 \quad 45.000000\end{array}$

$-14.70000 \quad 14.70000$

I

/ REMAINING CURVES 117 - 123

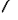

POINT (SELE, ID, WIND=1)

105

33

CURVE (ADD, SHOW, ARROW, ORDER=1)

POINT (SELE, ID, WIND=1)

60

64

CURVE (ADD, SHOW, ARROW, ORDER=1)

POINT (SELE, ID, WIND=1)

108

39

CURVE (ADD, SHOW, ARROW, ORDER=1)

POINT (SELE, ID, WIND =1)

85

81

CURVE (ADD, SHOW, ARROW, ORDER=1)

POINT (SELE, ID, WIND=1)

84

88

CURVE (ADD, SHOW, ARROW, ORDER=1)

POINT (SELE, ID, WIND=1) 
CURVE (ADD, SHOW, ARROW, ORDER=1)

POINT ( SELE, ID , WIND $=1$ )

44

61

CURVE (ADD, SHOW, ARROW, ORDER=1)

,

$/$ CURves 124 - 131

1

POINT (SELE, ID, WIND=1)

66

62

CURVE (ADD, SHOW, ARROW, ORDER=1)

POINT ( SELE, ID , WIND =1)

63

67

CURVE (ADD, SHOW, ARROW, ORDER=1)

POINT (SELE, ID, WIND=1)

82

78

CURVE (ADD, SHOW, ARROW, ORDER=1)

POINT (SELE, ID, WIND=1)

79

83

CURVE (ADD, SHOW, ARROW, ORDER=1)

POINT (SELE, ID, WIND=1)

90

86

CURVE (ADD, SHOW, ARROW, ORDER=1)

POINT ( SELE, ID, WIND=1)

87

91

CURVE ( ADD, SHOW , ARROW, ORDER=1)

POINT ( SELE, ID, WIND=1)

106

102

CURVE (ADD, SHOW, ARROW, ORDER=1)

POINT (SELE, ID, WIND=1)

103

107

CURVE (ADD, SHOW, ARROW, ORDER=1)

I

/ ADD MESH INTERVALS TO EDGES

/

CURVE ( SELECT, ID, WINDOW=1)

4

2

57

37

39

48

51

MEDGE (ADD, SHOW, SUCC, INTE $=5, \operatorname{RATI}=0.0,2 \mathrm{RAT}=0.0, \mathrm{PCEN}=0.0$ ) CURVE (SELECT, ID, WINDOW=1)

31

5

123

118

MEDGE (ADD, SHOW, SUCC, INTE $=5, \operatorname{RATI}=0.0,2 \mathrm{RAT}=0.0, \mathrm{PCEN}=0.0$ )

CURVE (SELECT, ID, WINDOW=1)

30

6

84

72

MEDGE (ADD, SHOW, SUCC, INTE $=4, \operatorname{RATI}=0.0,2 \mathrm{RAT}=0.0, \mathrm{PCEN}=0.0$ ) 
86

73

MEDGE (ADD, SHOW, SUCC, INTE=5, RATI =0.0, $2 \mathrm{RAT}=0.0, \mathrm{PCEN}=0.0$ ) CURVE (SELECT, ID, WINDOW=1)

28

8

82

91

87

74

MEDGE (ADD, SHOW, SUCC, INTE $=55, \operatorname{RATI}=0.0,2 \mathrm{RAT}=0.0, \mathrm{PCEN}=0.0$ ) CURVE (SELECT, ID, WINDOW=1)

27

9

81

90

88

75

MEDGE (ADD, SHOW, SUCC, INTE =5, RATI=0.0,2RAT=0.0, PCEN=0.0) CURVE (SELECT, ID, WINDOW=1)

26

10

80

76

MEDGE (ADD, SHOW, SUCC, INTE $=4, \operatorname{RATI}=0.0,2 \mathrm{RAT}=0.0, \mathrm{PCEN}=0.0$ )

CURVE (SELECT, ID, WINDOW $=1$ )

25

11

120

121

MEDGE (ADD, SHOW, SUCC, INTE=3, RATI=0.0,2RAT=0.0, PCEN=0.0) CURVE (SELECT, ID, WINDOW=1)

24

12

108

96

MEDGE (ADD, SHOW, SUCC, INTE=4, RATI =0.0, 2RAT=0.0,PCEN=0.0) CURVE (SELECT, ID, WINDOW=1)

23

13

107

116

110

97

MEDGE (ADD, SHOW, SUCC, INTE=5, RATI =0.0, 2RAT=0.0, PCEN=0.0) CURVE (SELECT, ID, WINDOW=1)

22

14

106

115

111

98

MEDGE (ADD , SHOW, SUCC, INTE $=55$, RATI $=0.0,2 \mathrm{RAT}=0.0, \mathrm{PCEN}=0.0$ )

CURVE (SELECT, ID, WINDOW=1)

21

15

105

114

112

99

MEDGE (ADD, SHOW, SUCC, INTE=5, RATI=0.0, $2 \mathrm{RAT}=0.0, \mathrm{PCEN}=0.0$ ) 
ELEMENT (SETD , EDGE , NODE =2 )

MEDGE (MESH, MAP, ENTI = "MCOSTRHS_PLOT")

MEDGE (SELECT, ID, WINDOW=1)

78

ELEMENT (SETD, EDGE, NODE=2)

MEDGE (MESH , MAP , ENTI = "MCOSTRHS_RAD")

MEDGE (SELECT, ID, WINDOW=1)

79

ELEMENT (SETD, EDGE, NODE=2)

MEDGE (MESH , MAP , ENTI = "MCOSTLHS_PLOT" )

MEDGE (SELECT, ID, WINDOW $=1$ )

79

ELEMENT (SETD, EDGE, NODE=2)

MEDGE (MESH, MAP, ENTI = "MCOSTLHS_RAD" )

MEDGE (SEIECT , ID, WINDON=1)

86

117

121

5

ELEMENT ( SETD, EDGE, NODE=2)

MEDGE (MESH, MAP, ENTI= "MCOOD_PLOT")

MEDGE (SELECT, ID, WINDOW=1)

86

117

121

5

ELEMENT (SETD, EDGE, NODE=2)

MEDGE (MESH, MAP, ENTI = "MCOOD_RAD")

MEDGE (SELECT, ID, WINDOW=1)

85

116

120

4

ELEMENT ( SETD , EDGE , NODE=2)

MEDGE (MESH , MAP , ENTI = "MCOID_PLOT")

MEDGE (SELECT, ID, WINDOW=1)

116

EIEMENT (SETD, EDGE , NODE=2)

MEDGE (MESH, MAP , ENTI = "MCOID_RAD1 ")

MEDGE (SELECT, ID, WINDOW=1)

120

ELEMENT (SETD, EDGE, NODE=2)

MEDGE (MESH , MAP , ENTI = "MCOID_RAD2 ")

MEDGE (SELECT, ID, WINDOW=1)

9

ELEMENT (SETD, EDGE, NODE=2)

MEDGE (MESH, MAP , ENTI = "VCROSS_RAD1")

MEDGE (SELECT, ID, WINDOW=1)

13

17

23

29

35

ELEMENT ( $S E T D$, EDGE, NODE=2)

MEDGE (MESH, MAP, ENTI = "VCROSS_RAD2 ")

MEDGE (SELECT, ID, WINDOW=1)

39

ELEMENT ( $S E T D$, EDGE, NODE =2)

MEDGE (MESH, MAP, ENTI="VCROSS_RAD3")

MEDGE (SELECT, ID, WINDOW=1) 
ELEMENT ( SETD, EDGE, NODE =2)

MEDGE (MESH, MAP , ENTI = "VCROSS_RAD4 ")

MEDGE ( SELECT, ID, WINDOW=1)

69

ELEMENT ( $S E T D$, EDGE, NODE $=2$ )

MEDGE (MESH, MAP, ENTI = "VCROSS_RAD5 ")

MEDGE ( SELECT, ID, WINDOW=1)

73

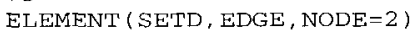

MEDGE (MESH, MAP, ENTI = "VCROSS_RAD6")

MEDGE (SELECT, ID , WINDOW=1)

90

ELEMENT (SETD, EDGE, NODE $=2$ )

MEDGE (MESH, MAP, ENT I = "HCROSS_RAD1 ")

MEDGE (SELECT, ID, WINDOW=1)

94

100

110

ELEMENT ( $S E T D$, EDGE, NODE=2)

MEDGE (MESH, MAP, ENTI = "HCROSS_RAD2 ")

MEDGE ( SELECT , ID , WINDOW=1)

70

ELEMENT ( $S E T D$, EDGE, NODE = 2)

MEDGE (MESH, MAP, ENTI = "HCROSS_RAD3 ")

MEDGE (SELECT, ID, WINDOW=1)

74

ELEMENT ( SETD, EDGE, NODE=2)

MEDGE (MESH, MAP, ENTI = "HCROSS_RAD4 ")

MEDGE (SELECT, ID, WINDOW=1)

95

101

111

ELEMENT ( $S E T D$, EDGE, NODE=2)

MEDGE (MESH, MAP, ENTI = "CAN1OD_RAD1")

MEDGE (SELECT , ID , WINDOW=1)

15

21

27

33

37

ELEMENT ( $S E T D$, EDGE , NODE =2)

MEDGE (MESH , MAP , ENTI = "CAN1OD_RAD2")

MEDGE (SELECT, ID, WINDOW=1)

112

104

96

ELEMENT ( $S E T D$, EDGE, NODE=2)

MEDGE (MESH, MAP , ENTI = "CAN1OD_RAD3")

MEDGE (SELECT, ID, WINDOW=1)

36

30

24

18

14

ELEMENT ( $S E T D$, EDGE, NODE $=2$ )

MEDGE (MESH, MAP, ENTI = "CAN1OD_RAD4 ")

MEDGE ( SELECT, ID , WINDOW=1)

95

101

111

15

21

27 
14

ELEMENT ( $S E T D$, EDGE, NODE=2)

MEDGE (MESH , MAP, ENTI = "CAN1OD_PLOT")

MEDGE ( SELECT, ID, WINDOW=1)

\section{2}

20

26

32

103

31

25

19

ELEMENT ( $S E T D$, EDGE, NODE=2)

MEDGE (MESH , MAP , ENTI = "CANIID_PLOT")

MEDGE ( SELECT, ID , WINDOW=1)

97

105

113

ELEMENT ( $S E T D$, EDGE, NODE $=2$ )

MEDGE (MESH , MAP , ENTI = "CAN2OD_RAD1 ")

MEDGE ( $S E L E C T, I D, W I N D O W=1$ )

45

51

57

63

67

ELEMENT ( SETD, EDGE, NODE=2)

MEDGE (MESH , MAP , ENTI = "CAN2OD_RAD2" )

MEDGE (SELECT, ID , WINDOW=1)

114

108

98

ELEMENT ( $S E T D$, EDGE, NODE $=2$ )

MEDGE (MESH, MAP , ENTI = "CAN2OD_RAD3")

MEDGE ( SELECT, ID, WINDOW=1)

66

60

54

48

44

ELEMENT ( SETD, EDGE, NODE $=2$ )

MEDGE (MESH, MAP, ENTI = "CAN2OD_RAD4 ")

MEDGE (SELECT , ID , WINDOW=1)

97

105

113

45

51

57

63

67

114

108

98

66

60

54 
MEDGE (SELECT, ID, WINDOW=1)

106

50

56

52

107

61

55

49

ELEMENT ( $S E T D$, EDGE , NODE $=2$ )

MEDGE (MESH , MAP , ENTI = "CAN2 ID_PLOT" )

1

/ MESH LOOPS AND MFACES

1

/ MESH LOOP \#1, MESH FACE \#1

I

CURVE ( SELECT, ID , WINDOW=1)

1

2

3

4

MLOOP (ADD , MAP , VISI, SHOW, EDG1=1, EDG2=1, EDG $3=1, E D G 4=1$ )

SURFACE (SELECT, ID, WINDOW=1)

1

UTILITY (HIGH=9)

MLOOP (SELECT, ID, WINDOW=1)

1

UTILITY ( $\mathrm{HIGH}=3$ )

$\operatorname{MFACE}(A D D)$

MFACE (SELECT, ID, WINDOW =1)

1

MFACE (MESH , MAP , ENTI = "CCROSS")

1

MESH LOOP \#2, MESH FACE \#2

/

CURVE ( SELECT , ID , WINDOW=1)

3

5

6

7

8

9

10

11

12

13

14

15

16

17

18

19

20

21

22

23

24

25 


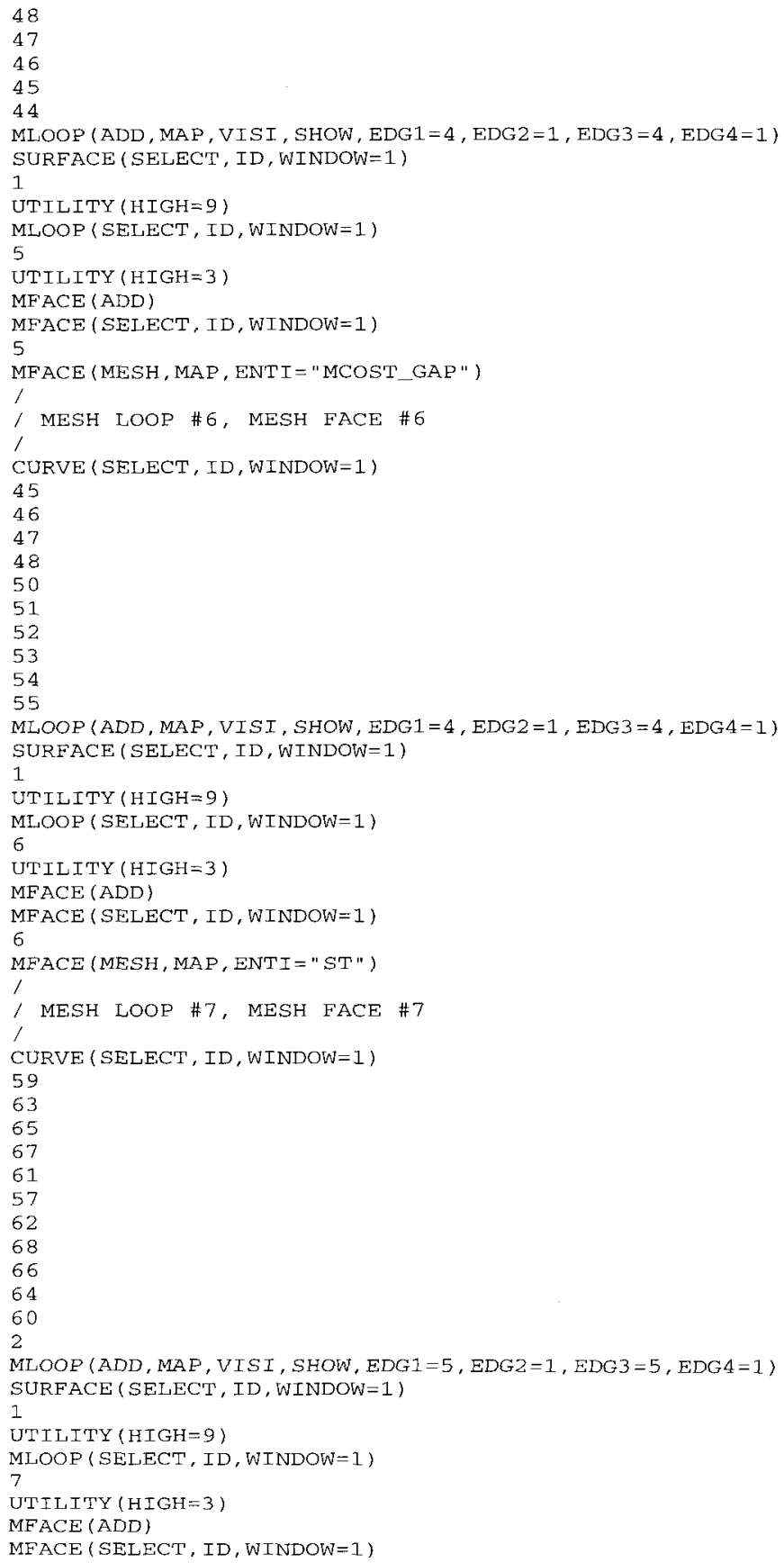


,

/ MESH LOOP \#8, MESH FACE \#8

1

CURVE (SELECT, ID, WINDOW=1)

58

37

56

57

MLOOP ( ADD, MAP , VISI , SHOW $, E D G 1=1, E D G 2=1, E D G 3=1, E D G 4=1$ )

SURFACE (SELECT, ID, WINDOW=1)

1

UTILITY (HIGH=9)

MLOOP (SELECT, ID, WINDOW=1)

8

UTILITY (HIGH=3)

MFACE (ADD)

MFACE (SELECT, ID, WINDOW $=1$ )

8

MFACE (MESH, MAP, ENTI = "MINI_GAP2 " )

1

/ MESH LOOP \#9, MESH FACE \#9

,

CURVE (SELECT, ID, WINDOW=1)

122

84

83

82

81

80

120

108

107

106

105

104

117

16

15

14

13

12

11

10

9

8

7

6

MLOOP (ADD, MAP , VISI, SHOW, $\mathrm{EDG} 1=1, \mathrm{EDG} 2=11, \mathrm{EDG} 3=1, \mathrm{EDG} 4=11$ )

SURFACE (SELECT, ID, WINDOW=1)

1

UTILITY (HIGH=9)

MLOOP (SELECT, ID, WINDOW=1)

9

UTILITY (HIGH=3)

MFACE (ADD)

MFACE (SELECT, ID, WINDOW=1)

9

MFACE (MESH , MAP , ENTI = "GAP1 ")

,

/ MESH LOOP \#10, MESH FACE \#10

,

CURVE (SELECT, ID, WINDOW=1) 
MLOOP (ADD, MAP, VISI, SHOW, EDG1=1, EDG2=1, EDG3=1, EDG4=1) 
$\operatorname{MFACE}(\mathrm{ADD})$

MFACE (SELECT, ID, WINDOW=1)

15

MFACE (MESH, MAP, ENTI = "FUEL1" )

/

/ MESH LOOP \#16, MESH FACE \#16

CURVE (SELECT, ID , WINDOW=1)

109

110

111

112

113

114

115

116

MLOOP (ADD, MAP, VISI , SHOW, EDG1=1, EDG2=3, EDG3=1, EDG4=3)

SURFACE (SELECT, ID, WINDOW=1)

1

UTILITY ( $\mathrm{HIGH}=9)$

MLOOP (SELECT, ID, WINDOW=1)

16

UTILITY (HIGH=3)

MFACE (ADD)

MFACE (SELECT, ID, WINDOW=1)

16

MFACE (MESH, MAP, ENTI = "FUEL2" )

I

$/$ MESH LOOP \#17, MESH FACE \#17

1

CURVE (SELECT, ID, WINDOW=1)

70

125

85

124

MLOOP (ADD, MAP , VISI, SHOW, EDG1=1, EDG2=1, EDG3=1, EDG4=1)

SURFACE (SELECT, ID, WINDOW=1)

1

UTILITY $(\mathrm{HIGH}=9)$

MLOOP (SELECT, ID, WINDOW=I)

17

UTILITY (HIGH=3)

MFACE (ADD)

MFACE (SELECT, ID, WINDOW=1)

17

MFACE (MESH, MAP , ENTI = "CAN11")

I

$/$ MESH LOOP \#18, MESH FACE \#18

I

CURVE (SELECT, ID, WINDOW=1)

71

72

73

74

75

76

77

127

88

87

86

125

MLOOP (ADD, MAP, VISI, SHOW, EDG1=1, EDG2=5, EDG3=1, EDG4=5)

SURFACE (SELECT, ID, WINDOW=1)

1

UTILITY (HIGH=9)
HNF-4109, Rev. 0

Appendix A 
$\operatorname{MFACE}(\mathrm{ADD})$

MEACE (SELECT , ID, WINDOW $=1$ )

18

MEACE (MESH, MAP, ENTI = "CAN12")

/

/ MESH LOOP \#19, MESH FACE \#19

I

CURVE (SELECT , ID, WINDOW=1)

89

127

78

126

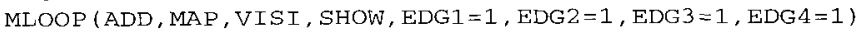

SURFACE (SELECT, ID, WINDOW=1)

1

UTILITY (HIGH=9)

MLOOP (SELECT, ID, WINDOW=1)

19

UTILITY ( $\mathrm{HIGH}=3)$

$\operatorname{MFACE}(\mathrm{ADD})$

MFACE (SELECT, ID, WINDOW=1)

19

MFACE (MESH, MAP, ENTI = "CAN13")

/

$/$ MESH LOOP \#20, MESH FACE \#20

I

CURVE (SELECT , ID, WINDOW=1)

69

124

92

91

90

126

79

80

81

82

83

84

MLOOP (ADD, MAP, VISI, SHOW, EDG1=1, EDG2=5, EDG3=1, EDG4=5)

SURFACE (SELECT, ID, WINDOW $=1$ )

1

UTILITY ( $\mathrm{HIGH}=9$ )

MLOOP (SELECT, ID, WINDOW=1)

20

UTILITY ( $\mathrm{HIGH}=3$ )

MFACE (ADD)

MFACE (SELECT, ID, WINDOW=1)

20

MFACE (MESH , MAP , ENTI = "CAN14")

1

/ MESH LOOP \#2I, MESH FACE \#21

1

CURVE (SELECT, ID, WINDOW=1)

94

129

109

128

MLOOP (ADD, MAP, VISI, SHOW, EDG1 =1, EDG2=1, EDG3 =1, EDG4=1)

SURFACE (SELECT, ID, WINDOW=1)

1 
MFACE (ADD)

MFACE (SELECT, ID, WINDOW=1)

21

MFACE (MESH, MAP, ENTI= "CAN21")

1

/ MESH LOOP \#22, MESH FACE \#22

1

CURVE (SELECT, ID, WINDOW=1)

95

96

97

98

99

100

101

131

112

111

110

129

MLOOP (ADD, MAP , VISI, SHOW, EDG1=1, EDG2=5, EDG3=1, EDG4=5)

SURFACE (SELECT, ID, WINDOW=1)

1

UTILITY ( $\mathrm{HIGH}=9)$

MLOOP (SELECT , ID, WINDOW=1)

22

UTILITY (HIGH=3)

MFACE (ADD)

MFACE (SEIECT, ID, WINDOW=1)

22

MFACE ( MESH, MAP, ENTI = "CAN22 " )

,

/ MESH LOOP \#23, MESH FACE \#23

1

CURVE (SELECT, ID, WINDOW =1)

113

131

102

130

MLOOP (ADD, MAP, VISI, SHOW, EDG1=1, EDG2=1, EDG3=1, EDG4=1)

SURFACE (SELECT, ID, WINDOW=1)

1

UTILITY ( HIGH=9)

MLOOP (SELECT, ID, WINDOW=1)

23

UTILITY (HIGH=3)

MFACE ( $A D D)$

MFACE (SELECT, ID, WINDOW=1)

23

MFACE (MESH, MAP, ENTI = "CAN23")

1

/ MESH LOOP \#24, MESH FACE \#24

1

CURVE (SELECT, ID, WINDOW=1)

93

128

116

115

114

130

103

104 


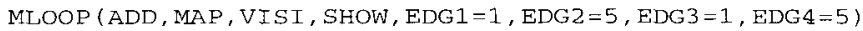


$\$ E 48=58689$
$\$ E 49=58840$
$\$ E 50=58991$
$\$ E 51=59142$
$\$ E 52=59293$
$\$ E 53=59444$
$\$ E 54=59595$
$\$ E 55=59746$
$\$ E 56=59897$
$\$ E 57=60048$
$\$ E 58=60199$
$\$ E 59=60350$
$\$ E 60=60501$
$\$ E 61=60652$
$\$ E 62=60803$
$\$ E 63=60954$
$\$ E 64=61105$
$\$ E 65=61256$
I

SANUM $=1$

$\$ C N U M=N T O S(\$ A N U M)$

1

DO ( $\$ A=1, \$ A \cdot L T \cdot 32,1)$

$\$ F C H A N=N T O S(\$ A)$

ELEMENT ( SELECT, ID, WINDOW=1)

$(\$ E 1+((\$ A-1) \star 5))$

$(\$ E 2+((\$ A-1) * 5))$

$(\$ E 3+((\$ A-1) * 5\rangle)$

$(\$ \mathrm{E} 4+((\$ \mathrm{~A}-1) * 5))$

$(\$ E 5+((\$ A-1) \star 5))$

$(\$ \mathrm{E} 6+((\$ \mathrm{~A}-1) \star 5\})$

$\{\$ E 7+((\$ A-1) * 5))$

$(\$ E 8+((\$ A-1) \star 5))$

$(\$ E 9+((\$ A-1) \star 5))$

$(\$ \mathrm{E} 10+((\$ \mathrm{~A}-1) * 5))$

$(\$ E I 1+((\$ A-1) * 5))$

$(\$ \mathrm{E} 12+((\$ A-1) * 5))$

$(\$ E 13+((\$ A-1) * 5))$

$(\$ \mathrm{E} 14+((\$ \mathrm{~A}-1) * 5))$

$(\$ \mathrm{E} 15+((\$ \mathrm{~A}-1) \star 5))$

$(\$ \mathrm{E} 16+((\$ A-1) * 5))$

$(\$ \mathrm{E} 17+((\$ \mathrm{~A}-1) * 5))$

$\left(\$ E_{1} 18+((\$ A-1) * 5)\right)$

$(\$ E 19+((\$ A-1) \star 5))$

$(\$ \mathrm{E} 20+((\$ A-1) * 5))$

$(\$ \mathrm{E} 21+((\$ \mathrm{~A}-1) * 5))$

$(\$ \mathrm{E} 22+((\$ \mathrm{~A}-1) \star 5))$

$(\$ E 23+((\$ A-1) \star 5))$

$(\$ \mathrm{E} 24+((\$ \mathrm{~A}-1) \star 5))$

$(\$ E 25+((\$ A-1) * 5))$

$(\$ E 26+((\$ A-1) * 5))$

$(\$ E 27+((\$ A-1) * 5))$

$(\$ \mathrm{E} 28+((\$ A-1) * 5))$

$(\$ E 29+((\$ A-1) * 5))$

$(\$ E 30+((\$ A-1) * 5))$

$(\$ E 31+((\$ A-1) * 5))$

$(\$ \mathrm{E} 32+((\$ A-1) \star 5))$

$(\$ E 33+((\$ A-1) * 5))$

$(\$ E 34+((\$ A-1) * 5))$

$(\$ E 35+((\$ A-1) * 5))$

$\left(\$ \mathrm{E}_{3} 6+((\$ A-1) * 5)\right)$

$(\$ E 37+((\$ A-1) \star 5))$

$(\$ E 38+((\$ A-1) * 5))$

$(\$ E 39+((\$ A-1) \star 5))$

$(\$ E 40+((\$ A-1) \star 5)\}$

$(\$ \mathrm{E} 41+((\$ \mathrm{~A}-1) \star 5))$ 
$(\$ \mathrm{E} 30+9815+((\$ \mathrm{~B}-1) * 5))$

$(\$ E 31+9815+((\$ B-1) \star 5))$

$(\$ \mathrm{E} 32+9815+((\$ B-1) * 5))$

$(\$ \mathrm{E} 33+9815+((\$ \mathrm{~B}-1) * 5))$

$(\$ E 34+9815+((\$ B-1) * 5))$

$(\$ E 35+9815+((\$ B-1) \star 5))$

$(\$ E 36+9815+((\$ B-1) * 5))$

$(\$ \mathrm{E} 37+9815+((\$ \mathrm{~B}-1) * 5))$

$(\$ \mathrm{E} 38+9815+((\$ B-1) * 5))$

$(\$ E 39+9815+((\$ B-1) * 5))$

$(\$ \mathrm{E} 40+9815+((\$ \mathrm{~B}-1) \star 5))$

$(\$ E 41+9815+((\$ B-1) * 5))$

$(\$ E 42+9815+((\$ B-1) \star 5))$

$(\$ F 43+9815+((\$ B-1) \star 5))$

$(\$ E 44+9815+((\$ B-1) * 5))$

$(\$ E 45+9815+((\$ B-1) \star 5))$

$(\$ E 46+9815+((\$ B-1) \star 5))$

$(\$ E 47+9815+((\$ B-1) \star 5))$

$(\$ E 48+9815+((\$ B-1) * 5))$

$(\$ E 49+9815+((\$ B-1) * 5))$

$(\$ E 50+9815+((\$ B-1) \star 5))$

$(\$ E 51+9815+((\$ B-1) * 5))$

$(\$ E 52+9815+((\$ B-1) * 5))$

$(\$ E 53+9815+((\$ B-1) \star 5))$

$(\$ E 54+9815+((\$ B-1) \star 5))$

$(\$ E 55+9815+((\$ B-1) * 5))$

$(\$ 556+9815+((\$ B-1) * 5))$

$(\$ \mathrm{E} 57+9815+((\$ B-1) \star 5))$

$(\$ E 58+9815+((\$ B-1) * 5))$

$(\$ E 59+9815+((\$ B-1) * 5))$

$(\$ E 60+9815+((\$ B-1) * 5))$

$(\$ E 61+9815+((\$ B-1) * 5))$

$(\$ E 62+9815+((\$ B-1) \star 5))$

$(\$ E 63+9815+((\$ B-1) * 5))$

$(\$ E 64+9815+((\$ B-1) * 5))$

$(\$ E 65+9815+((\$ B-1) \star 5))$

ELEMENT (MODIFY , GROUP $=91+\$ B, N O D E=4$, QUAD)

$\$ G R P=91+\$ B$

EGROUP (SELECT, ID, WINDOW=1)

\$GRP

EGROUP (MODIFY, ENT ITY = " FLOW" + \$CNUM+ \$FCHAN)

ENDDO

$/$

$/$ SEPARATE CLADDING + RIBBING GROUPS

$\gamma$

$\$ A N U M=1$

$\$ C N U M=N T O S$ ( $\$$ ANUM $)$

1

DO ( $\$ \mathrm{C}=1, \$ \mathrm{C} . \mathrm{LT}, 31,1)$

$\$ F C H A N=N T O S(\$ C)$

ELEMENT (SELECT, ID, WINDOW=1)

$(\$ \mathrm{E} 1+1+((\$ \mathrm{C}-1) * 5))$

$(\$ \mathrm{E} 2+1+((\$ \mathrm{C}-1) * 5))$

$(\$ \mathrm{E} 3+1+((\$ \mathrm{C}-1) * 5))$

$(\$ \mathrm{E} 4+1+((\$ \mathrm{C}-1) * 5))$

$(\$ \mathrm{E} 5+1+((\$ \mathrm{C}-1) \star 5))$

$(\$ \mathrm{E} 6+1+((\$ \mathrm{C}-1) * 5))$

$(\$ \mathrm{E} 7+1+((\$ \mathrm{C}-1) * 5))$

$(\$ \mathrm{E} 8+1+((\$ C-1) * 5))$

$(\$ \mathrm{E} 9+1+((\$ \mathrm{C}-1) * 5))$

$(\$ \mathrm{E} 10+1+((\$ \mathrm{C}-1) * 5))$

$(\$ \mathrm{E} 11+1+((\$ \mathrm{C}-1) * 5))$

$(\$ \mathrm{E} 12+1+((\$ \mathrm{C}-1) * 5))$

$(\$ \mathrm{E} 13+1+((\$ \mathrm{C}-1) * 5))$

$(\$ \mathrm{El} 4+1+((\$ \mathrm{C}-1) * 5))$

$(\$ \mathrm{E} 15+1+((\$ \mathrm{C}-1) * 5))$ 
$(\$ \mathrm{E} 41+1+9815+((\$ \mathrm{D}-1) \star 5))$

$(\$ E 42+1+9815+(\langle \$ D-1) \star 5))$

$(\$ E 43+1+9815+((\$ D-1) * 5))$

$(\$ E 44+1+9815+((\$ D-1) * 5))$

$(\$ E 45+1+9815+((\$ D-1) \star 5))$

$(\$ E 46+1+9815+((\$ D-1) * 5))$

$(\$ E 47+1+9815+((\$ D-1) \star 5))$

$(\$ E 48+1+9815+((\$ D-1) * 5))$

$(\$ E 49+1+9815+((\$ D-1) \star 5))$

$(\$ E 50+1+9815+((\$ D-1) * 5))$

$(\$ E 51+1+9815+((\$ D-1) * 5))$

$(\$ E 52+1+9815+((\$ D-1) * 5))$

$(\$ E 53+1+9815+((\$ D-1) * 5))$

$(\$ E 54+1+9815+((\$ D-1) * 5))$

$(\$ \mathrm{E} 55+1+9815+((\$ D-1) * 5))$

$(\$ E 56+1+9815+((\$ D-1) * 5))$

$(\$ \mathrm{E} 57+1+9815+((\$ D-1) * 5))$

$(\$ E 58+1+9815+((\$ D-1) * 5)\}$

$(\$ E 59+1+9815+((\$ D-1) * 5))$

$(\$ E 60+1+9815+(\langle \$ D-1\rangle * 5))$

$(\$ E 61+1+9815+((\$ D-1) * 5))$

$(\$ E 62+1+9815+((\$ D-1) \star 5))$

$(\$ \mathrm{E} 63+1+9815+((\$ \mathrm{D}-1) * 5))$

$(\$ \mathrm{E} 64+1+9815+((\$ \mathrm{D}-1) \star 5))$

$(\$ \mathrm{E} 65+1+9815+((\$ \mathrm{D}-1) \star 5))$

$(\$ E 1+2+9815+((\$ D-1) * 5))$

$(\$ E 2+2+9815+((\$ D-1) \star 5))$

$(\$ E 3+2+9815+((\$ D-1) * 5))$

$(\$ E 9+2+9815+(\langle \$ D-1) * 5))$

$(\$ E 15+2+9815+((\$ D-1) \star 5))$

$(\$ E 21+2+9815+((\$ D-1) \star 5))$

$(\$ E 27+2+9815+((\$ D-1) * 5))$

$(\$ E 33+2+9815+((\$ D-1) * 5))$

$(\$ E 39+2+9815+((\$ D-1) * 5))$

$(\$ E 45+2+9815+((\$ D-1) \star 5))$

$(\$ E 51+2+9815+((\$ D-1) * 5))$

$(\$ E 57+2+9815+((\$ D-1) * 5))$

$(\$ E 63+2+9815+((\$ D-1) * 5))$

$(\$ E 64+2+9815+((\$ D-1) * 5))$

$(\$ E 65+2+9815+((\$ D-1) * 5))$

$(\$ E 1+3+9815+((\$ D-1) * 5))$

$(\$ E 2+3+9815+((\$ D-1) \star 5))$

$(\$ E 3+3+9815+((\$ D-1) * 5))$

$(\$ \mathrm{E} 9+3+9815+((\$ \mathrm{D}-1) \star 5))$

$(\$ \mathrm{E} 15+3+9815+((\$ D-1) * 5))$

$(\$ E 21+3+9815+((\$ D-1) * 5))$

$(\$ E 27+3+9815+((\$ D-1) * 5))$

$\langle \$ \mathrm{E} 33+3+9815+((\$ \mathrm{D}-1) \star 5)\rangle$

$(\$ E 39+3+9815+((\$ D-1) \star 5))$

$(\$ E 45+3+9815+((\$ D-1) * 5))$

$(\$ \mathrm{E} 51+3+9815+((\$ \mathrm{D}-1) * 5))$

$(\$ \mathrm{E} 57+3+9815+((\$ \mathrm{D}-1) \star 5))$

$(\$ E 63+3+9815+((\$ D-1) \star 5))$

$(\$ \mathrm{E} 64+3+9815+((\$ D-1) * 5))$

$(\$ \mathrm{E} 65+3+9815+((\$ \mathrm{D}-1) * 5))$

$(\$ E 1+4+9815+((\$ D-1) * 5))$

$(\$ E 2+4+9815+((\$ D-1) * 5))$

$(\$ \mathrm{E} 3+4+9815+((\$ \mathrm{D}-1) * 5))$

$(\$ E 4+4+9815+((\$ D-1) * 5))$

$(\$ E 5+4+9815+((\$ D-1) * 5))$

$(\$ \mathrm{E} 6+4+9815+((\$ \mathrm{D}-1) * 5))$

$(\$ E 7+4+9815+((\$ D-1) * 5))$

$(\$ E 8+4+9815+(\langle \$ D-1) * 5)\rangle$

$(\$ E 9+4+9815+((\$ D-1) * 5))$

$(\$ E 10+4+9815+((\$ D-1) * 5))$

$(\$ E 11+4+9815+((\$ D-1) * 5))$
HNF-4109, Rev. 0

Appendix A 
$\begin{array}{lr}(\$ E 12+4+9815+((\$ D-1) \star 5)) & \text { HNF-4109, Rev. 0 } \\ (\$ E 13+4+9815+((\$ D-1) * 5)) & \text { Appendix A }\end{array}$

(SE15+4+9815+((SD-1)*5)

$(\$ \mathrm{E} 16+4+9815+((\$ D-1) \star 5))$

$(\$ \mathrm{E} 17+4+9815+((\$ \mathrm{D}-1) \star 5))$

$(\$ E 18+4+9815+((\$ D-1) * 5))$

$(\$ \mathrm{E} 19+4+9815+((\$ D-1) \star 5))$

$(\$ \mathrm{E} 20+4+9815+((\$ \mathrm{~S}-1) \star 5))$

$(\$ E 21+4+9815+((\$ D-1) * 5))$

$(\$ \mathrm{E} 22+4+9815+((\$ \mathrm{D}-1) \star 5))$

$(\$ E 23+4+9815+((\$ D-1) * 5))$

$(\$ \mathrm{E} 24+4+9815+((\$ \mathrm{D}-1) * 5))$

$(\$ E 25+4+9815+((\$ D-1) * 5))$

$(\$ E 26+4+9815+((\$ D-1) * 5))$

$(\$ \mathrm{E} 27+4+9815+((\$ D-1) * 5))$

$(\$ E 28+4+9815+((\$ D-1) * 5))$

$(\$ E 29+4+9815+((\$ D-1) * 5))$

$(\$ E 30+4+9815+((\$ D-1) * 5))$

$(\$ E 31+4+9815+((\$ D-1) * 5))$

$(\$ E 32+4+9815+((\$ D-1) \star 5))$

$(\$ \mathrm{E} 33+4+9815+((\$ \mathrm{D}-1) * 5))$

$(\$ \$ 34+4+9815+((\$ D-1) * 5))$

$(\$ \mathrm{E} 35+4+9815+((\$ D-1) * 5))$

$(\$ E 36+4+9815+((\$ D-1) * 5))$

$(\$ \mathrm{E} 37+4+9815+((\$ D-1) * 5))$

$(\$ E 38+4+9815+((\$ D-1) * 5))$

$(\$ 239+4+9815+((\$ D-1) * 5))$

$(\$ E 40+4+9815+((\$ D-1) * 5))$

$(\$ E 41+4+9815+((\$ D-1) * 5))$

$(\$ E 42+4+9815+((\$ D-1) \star 5))$

$(\$ E 43+4+9815+((\$ D-1) * 5))$

$(\$ E 44+4+9815+((\$ D-1) * 5))$

$(\$ 245+4+9815+((\$ D-1) * 5))$

$(\$ E 46+4+9815+((\$ D-1) \star 5))$

$(\$ E 47+4+9815+((\$ D-1) * 5))$

$(\$ \mathrm{E} 48+4+9815+((\$ \mathrm{D}-1) * 5))$

$(\$ \mathrm{E} 49+4+9815+((\$ D-1) \star 5))$

$(\$ \mathrm{E} 50+4+9815+((\$ D-1) \star 5))$

$(\$ \mathrm{E} 51+4+9815+((\$ D-1) * 5))$

$(\$ \mathrm{E} 52+4+9815+((\$ D-1) * 5))$

$(\$ \mathrm{E} 53+4+9815+((\$ \mathrm{D}-1) \star 5))$

$(\$ \mathrm{E} 54+4+9815+((\$ D-1) * 5))$

$(\$ \mathrm{E} 55+4+9815+((\$ \mathrm{D}-1) * 5))$

$(\$ \mathrm{E} 56+4+9815+((\$ D-1) * 5))$

$(\$ E 57+4+9815+((\$ D-1) * 5))$

$(\$ \mathrm{E} 58+4+9815+((\$ D-1) * 5))$

$(\$ \mathrm{E} 59+4+9815+((\$ \mathrm{D}-1) * 5))$

$(\$ \mathrm{E} 60+4+9815+((\$ D-1) * 5))$

$(\$ \mathrm{E} 61+4+9815+((\mathrm{SD}-1) \star 5))$

$(\$ \mathrm{E} 62+4+9815+((\$ \mathrm{D}-1) \star 5))$

$(\$ \mathrm{E} 63+4+9815+((\$ \mathrm{D}-1) * 5))$

$(\$ \mathrm{E} 64+4+9815+((\$ \mathrm{D}-1) * 5))$

$(\$ E 65+4+9815+((\$ D-1) * 5))$

ELEMENT (MODIFY, GROUP $=152+\$ D, N O D E=4, Q U A D)$

$\$ G R P=152+\$ D$

EGROUP (SELECT, ID, WINDOW=1)

\$GRP

EGROUP (MODIFY, ENTITY = "CLAD" + \$CNUM+ \$FCHAN)

ENDDO

1

END

FIPREP

( CONVERT FROM INCHES TO METERS

SCALE $(X=0.0254, Y=0.0254, Z=0.0254)$

/SI UNITS USED FROM THIS POINT ON 
DATAPRINT (NONE)

/ DATAPRINT (NORMAL, PAGE, NODES, ELEMENTS, CONSTRAINED, FLUX, INITIAL, GENERAL)

EXECUTABLE (NEWJOB)

GRAVITY (MAGNITUDE $=9.8066352, \mathrm{THETA}=0$ )

POSTPROCESS (RESIDUAL)

PRESSURE (DISCONTINUOUS, PENALTY=1. OE-8)

/PRINTOUT (ALL)

PRINTOUT (NONE)

PROBLEM ( INCOMPRESSIBLE, STEADY , NONLINEAR, NEWTONIAN, 2 -D , NOMOMENTUM, LAMTNAR, ENERGY)

/SOLUTION $(S E G R=50, \mathrm{VELCONV}=0.001, \mathrm{CR}=2000, \mathrm{CGS}=2000, \mathrm{NCGC}=1 \mathrm{E}-6, \mathrm{SCGC}=1 \mathrm{E}-6$, PRECON=21)

SOLUTION (S.S. $=100$, VELCONV $=0.001$, RESCONV $=0.001, S C H A N G E=0)$

EXTRA.POLATION (OFF)

/ EXTRAPOLATION (ON, AFTER=25, EVERY=15, ORDER=2, NOKE, NOFREE)

/ EXTRAPOLATION (ON, AFTER=5, EVERY=5, ORDER=2, NOKE, NOFREE)

CLIPPING (MINTMUM)

$0,0,0,0,333.15,0,0,0,1 E-20,1 E-20,1 E-20,1 E-20,1 E-20,1 E-20$,

$0,0,0,0,0,0,0,0,0,0,0,0,0,0$

CLIPPING (MAXIMUM)

$0,0,0,0,1000.0,0,0,0,0.1403,0.0248,0.3814,0.7552,0.0836,0.2448$,

$0,0,0,0,0,0,0,0,0,0,0,0,0,0$

RELAXATION (RADIATION=0.90)

$0.30,0.30,0.30,0.75,0.75,0.0,0.0,0.0,0.0001,0.05,0.05,0.05,0.05,0.05$,

$0.0,0.0,0.0,0.0,0.0,0.0,0.0,0.0,0.0,0,0,0.0,0.0,0.0,0.0$

/OPTIONS (UPWINDING $=7$ )

/

, ENTITY NAMES AND ATTRIBUTES

/

1

FLUIDS

1

ENTITY (NAME= "MCOST_GAP" , SOLID, PROPERTY= "AIR")

ENTITY (NAME= "MINI_GAP1 ", SOLID, PROPERTY= "AIR" )

ENTITY (NAME= "MINI_GAP2", SOLID, PROPERTY= "AIR" )

ENTITY (NAME= "GAP1" ", SOLID, PROPERTY = "AIR")

ENTITY (NAME = "GAP2" , SOLID, PROPERTY = "AIR ")

ENTITY (NAME= "GAP3 " , SOLID, PROPERTY= "AIR ")

ENTITY (NAME= "ASMBLY_GAP" , SOLID, PROPERTY= "AIR")

ENTITY (NAME = "FLOW1" , SOLID, PROPERTY="AIR")

ENTITY (NAME = " ELOW2 ", SOLID, PROPERTY= "AIR" )

1

SOLIDS

I

ENTITY (NAME= "ST" , SOLID, PROPERTY= "MCSTEEL" )

ENTITY (NAME= "MCO", SOLID, PROPERTY=" SS304")

ENTITY (NAME= "VCROSS", SOLID, PROPERTY="SS304")

ENTITY (NAME= " CCROSS", SOLID, PROPERTY = "SS304")

ENTITY (NAME = "HCROSS", SOLID, PROPERTY=" \$S304")

ENTITY (NAME = "CAN11 ", SOLID, PROPERTY= "ZIRC4" )

ENTITY (NAME= "CAN12" , SOLID, PROPERTY= "ZIRC4" )

ENTITY (NAME = "CAN13",SOLID, PROPERTY = "ZIRC4")

ENTITY (NAME = "CAN14 ", SOLID, PROPERTY = "ZIRC4")

ENTITY (NAME = "CAN21", SOLID, PROPERTY = "ZIRC4" )

ENTITY (NAME = "CAN22", SOLID, PROPERTY = "ZIRC4")

ENTITY (NAME= "CAN2 3 ", SOLID, PROPERTY= "ZIRC4" )

ENTITY (NAME = "CAN2 4",SOLID, PROPERTY= "ZIRC4")

ENT ITY (NAME = "FUEL1" , SOLID, PROPERTY = "UO2 " , MCOND= "UOZX")

ENTITY (NAME = "EUEL2 ", SOLID, PROPERTY= "UO2 " , MCOND= "UO2X")

I

$/$ FLOW CHANNELS - REVISED ELEMENT GROUPINGS

ENTITY (NAME= " FLOWI1", SOLID, PROPERTY= "AIR" , MCOND= "AIR2X")

ENTITY (NAME= "FLOW12", SOLID, PROPERTY= "AIR" , MCOND="AIR3X")

ENTITY (NAME= "FLOW13" , SOLID, PROPERTY="AIR" , MCOND= "AIR3X")

ENTITY (NAME= "FLOW14 ", SOLID, PROPERTY = "AIR" , MCOND="AIR3X") 
ENTITY (NAME= "FLOW15" , SOLID, PROPERTY= "AIR" , MCOND="AIR3X") ENTITY (NAME= " FLOW16" , SOLID, PROPERTY= "AIR" , MCOND="AIR3X") ENTITY (NAME= "FLOW1 7", SOLID, PROPERTY= "AIR", MCOND= "AIR3X") ENTITY (NAME= " FLOW18 " , SOLID, PROPERTY= "AIR", MCOND= "AIR3X") ENTITY (NAME=" FLOW19" , SOLID, PROPERTY= "AIR" , MCOND="AIR3X") ENTITY (NAME = "FLOW110", SOLID, PROPERTY= "AIR" , MCOND= "AIR3X") ENTITY (NAME=" FLOW111" , SOLID, PROPERTY= "AIR" , MCOND= "AIR3X") ENTITY (NAME= "FLOW112", SOLID, PROPERTY= "AIR", MCOND="AIR 3X") ENTITY (NAME = "FLOW113" , SOLID, PROPERTY= "AIR", MCOND= "AIR3X") ENTITY (NAME= " FLOW1 14", SOLID, PROPERTY= "AIR" , MCOND= "AIR3X") ENTITY (NAME= "FLOW1 15", SOLID, PROPERTY="AIR", MCOND= "AIR3X") ENTITY (NAME = "FLOW1 16", SOLID, PROPERTY = "AIR" , MCOND= "AIR3X") ENTITY (NAME= "FI,OW1 17", SOLID, PROPERTY = "AIR" , MCOND= "AIR3X") ENTITY (NAME= "FIOW1 18 ", SOLID, PROPERTY= "AIR", MCOND= "AIR3X") ENTITY (NAME= "FLOW119", SOIID, PROPERTY="AIR" , MCOND= "AIR3X") ENTITY (NAME = "FLOW120" , SOLID, PROPERTY = "AIR " , MCOND= "AIR3X") ENTITY (NAME= "FLOW121", SOIID, PROPERTY = "AIR" , MCOND="AIR3X") ENTITY (NAME = "FLOWI22", SOLID, PROPERTY="AIR" , MCOND= "AIR3X") ENTITY (NAME= " FLOW123", SOLID, PROPERTY= "AIR" , MCOND= "AIR3X") ENTITY (NAME= "FLOW124 ", SOLID, PROPERTY= "AIR", MCOND= "AIR3X") ENTITY (NAME= "FLOW125", SOLID, PROEERTY= "AIR" , MCOND="AIR3X") ENTITY (NAME= "FLOW126", SOLID, PROPERTY= "AIR" , MCOND= "AIR3X") ENTITY (NAME= " FLOW127", SOLID, PROPERTY="AIR" , MCOND= "AIR 3X") ENTITY (NAME=" FLOW128", SOLID, PROPERTY= "AIR" , MCOND= "AIR3X") ENTITY (NAME= "FLOW129" , SOLID, PROPERTY= "AIR" , MCOND= "AIR3X") ENTITY (NAME= "FLOW130", SOIID, PROPERTY= "AIR" , MCOND= "AIR3X") ENTITY (NAME="FLOW131", SOLID, PROPERTY="AIR", MCOND="AIR2X") ENTITY (NAME = " FLOW21" , SOLID , PROPERTY = "AIR", MCOND= "AIR2X") ENTITY (NAME = "FLOW22 ", SOLID, PROPERTY = "AIR", MCOND= "AIR3X") ENTITY (NAME= "FLOW2 3" , SOLID, PROPERTY= "AIR" , MCOND= "AIR3X") ENTITY (NAME= "FIOW24 ", SOLID, PROPERTY= "AIR", MCOND="AIR3X") ENTITY (NAME= "FLOW25" , SOLID, PROPERTY= "AIR", MCOND= "AIR3X") ENTITY (NAME= "FLOW26" , SOLID, PROPERTY = "AIR" , MCOND="AIR3X") ENTITY (NAME= " FLOW27" , SOLID, PROPERTY = "AIR" , MCOND= "AIR3X") ENTITY (NAME= " FLOW2 8" , SOLID, PROPERTY= "AIR" , MCOND= "AIR3X") ENTITY (NAME= "FLOW29" , SOLID, PROPERTY= "AIR", MCOND= "AIR3X") ENTITY (NAME = "FLOW210" , SOLID, PROPERTY= "AIR" , MCOND= "AIR3X") ENTITY (NAME= " FLOW211", SOLID, PROPERTY= "AIR", MCOND= "AIR3X") ENTITY (NAME = "FLOW212" , SOLID, PROPERTY= "AIR" , MCOND= "AIR 3X") ENTITY (NAME= "FLOW213", SOLID, PROPERTY= "AIR" , MCOND= "AIR3X") ENTITY (NAME= " FLOW2 14 ", SOLID, PROPERTY= "AIR" , MCOND= "AIR3X") ENTITY (NAME= " FLOW2 15", SOLID, PROPERTY= "AIR", MCOND="AIR3X") ENTITY (NAME= " FLOW2 16" , SOLID, PROPERTY = "AIR" , MCOND= "AIR3X") ENTITY (NAME= " FLOW217" , SOLID, PROPERTY= "AIR", MCOND= "AIR $3 X "$ ) ENTITY (NAME= " FLOW218", SOLID, PROPERTY= "AIR" , MCOND= "AIR3X") ENTITY (NAME = " FLOW219" , SOLID, PROPERTY= "AIR" , MCOND= "AIR3X") ENTITY (NAME= "FLOW220", SOLID, PROPERTY= "AIR" , MCOND= "AIR3X") ENTITY (NAME = "FLOW2 21 ", SOLID, PROPERTY= "AIR" , MCOND= "AIR $3 X^{\prime \prime)}$ ENTITY (NAME= "FLOW2 22 ", SOIID, PROPERTY= "AIR" , MCOND="AIR3X") ENTITY (NAME= " FLOW2 23 ", SOLID, PROPERTY= "AIR" , MCOND= "AIR3X") ENTITY (NAME= "FLOW2 24 ", SOLID, PROPERTY = "AIR" , MCOND= "AIR3X") ENTITY (NAME= " FLOW2 25" , SOLID, PROPERTY= "AIR" , MCOND= "AIR 3X") ENT ITY (NAME= "FI,OW2 26" , SOLID, PROPERTY= "AIR" , MCOND= "AIR3X") ENTITY (NAME= "FLOW2 27" , SOLID, PROPERTY = "AIR ", MCOND= "AIR3X") ENT ITY (NAME= "FLOW2 28 ", SOLID, PROPERTY= "AIR", MCOND= "AIR3X") ENTITY (NAME= " FLOW2 29" , SOLID, PROPERTY= "AIR" , MCOND= "AIR3X") ENTITY (NAME= " FLOW230" , SOLID, PROPERTY = "AIR ", MCOND= "AIR3X") ENTITY (NAME= "FLOW2 31 " , SOLID, PROPERTY= "AIR " , MCOND= "AIR2X") $/$ $/$ CLAD + RIBBING - REVISED ELEMENT GROUPINGS I

ENTITY (NAME= "CLAD11", SOLID, PROPERTY="ZIRC4 ", MCOND="ZIRCZX") ENTITY (NAME= "CLAD12", SOLID, PROPERTY="ZIRC4 ", MCOND=" ZIRC2X") ENTITY (NAME = "CLAD13", SOLID, PROPERTY = "ZIRC4 " MCOND= "ZIRC2X") ENTITY (NAME = "CLAD1 4", SOLID, PROPERTY = "ZIRC4 ", MCOND= " ZIRC2X") ENTITY (NAME $=$ "CLADI 5 ", SOLID, PROPERTY = "ZIRC4 ", MCOND=" ZIRC2X")
HNF-4109, Rev. 0

Appendix A 
ENTITY (NAME= "CLAD16" , SOLID, PROPERTY= "ZIRC4 " , MCOND= "ZIRC2X") ENTITY (NAME= "CLAD17" , SOIID, PROPERTY="ZIRC4" , MCOND= "ZIRC2X") ENTITY (NAME= "CLAD18" , SOLID, PROPERTY= " ZIRC4 " , MCOND= "ZIRC2X") ENTITY (NAME = "CLAD19" , SOLID, PROPERTY= " ZIRC4 " MCOND= "ZIRC2X") ENTITY (NAME= "CLAD1 $10 "$ ", SOLID, PROPERTY= "ZIRC4", MCOND="ZIRC2X") ENTITY (NAME= "CLAD111" , SOLID, PROPERTY = "ZIRC4" , MCOND="ZIRC2X") ENTITY (NAME= "CLAD1 12", SOLID, PROPERTY = "ZIRC4" , MCOND= "ZIRC2X") ENTITY $($ NAME $=$ " CLAD1 13 ", SOLID, PROPERTY = " ZIRC4 ", MCOND= " ZIRC2X") ENTITY (NAME= "CLAD1 14" , SOLID, PROPERTY= "ZIRC4 ", MCOND= "ZIRC2X") EN'TITY (NAME= "CLAD115" , SOLID, PROPERTY=" ZIRC4 ", MCOND="ZIRC2X") ENTITY (NAME= "CLAD116", SOLID, PROPERTY=" ZIRC4 ", MCOND= "ZIRC2X") ENTITY (NAME= "CLAD117", SOLID, PROPERTY="ZIRC4 ", MCOND="ZIRC2X") ENTITY (NAME= "CLAD1 18", SOLID, PROPERTY= "ZIRC4 ", MCOND="ZIRC2X") EN'TITY (NAME= "CLAD119", SOLID, PROPERTY= "ZIRC4" , MCOND= "ZIRC2X") ENTITY (NAME= "CLAD120" , SOLID, PROPERTY = "ZIRC4 " , MCOND= "ZIRC2X" ) ENTITY (NAME= "CLAD121" , SOLID, PROPERTY=" ZIRC4" , MCOND= "ZIRC2X") ENTITY (NAME= " CLAD122" , SOLID, PROPERTY= "ZIRC4 ", MCOND="ZIRC2X") ENTITY (NAME = "CLAD1 23 " , SOLID, PROPERTY= " ZIRC4 ", MCOND= "ZIRC2X") ENTITY (NAME:= "CLAD1 24", SOLID, PROPERTY="ZIRC4", MCOND= "ZIRC2X") ENTITY (NAME= "CLAD125", SOLID, PROPERTY= "ZIRC4 ", MCOND= "ZIRC2X") ENTITY (NAME= "CLAD126" , SOLID, PROPERTY= "ZIRC4 " , MCOND= "ZIRC2X") EN'TITY (NAME= "CLAD127" SOLID, PROPERTY = " ZIRC4 ", MCOND= " ZIRC2X") ENTITY (NAME= "CLAD128", SOLID, PROPERTY=" ZIRC4 ", MCOND= "ZIRC2X") ENTITY (NAME= "CLAD129", SOLID, PROPERTY= "ZIRC4", MCOND= "ZIRC2X") ENTITY (NAME = "CLAD130" , SOLID, PROPERTY= "ZIRC4 ", MCOND= "ZIRC2X") ENTITY (NAME = " CLAD21 " , SOLID, PROPERTY= " ZIRC4 ", MCOND= " ZIRC2X") ENTITY (NAME= "CLAD22 ", SOLID, PROPERTY= " ZIRC4 " , MCOND= " ZIRC2X") ENTITY (NAME= "CLAD2 3" , SOLID, PROPERTY= " ZIRC4 ", MCOND= " ZIRC2X") ENTITY (NAME = "CLAD24" , SOLID, PROPERTY= "ZIRC4 ", MCOND= "ZIRC2X") ENTITY (NAME = "CLAD25", SOLID, PROPERTY="ZIRC4" MCOND= "ZIRCZX") ENTITY (NAME= "CLAD26" , SOLID, PROPERTY=" ZIRC4 " , MCOND= " ZIRC2X") ENTITY (NAME = "CIAD27" , SOLID, PROPERTY= " ZIRC4 " , MCOND= " ZIRC2X") ENTITY (NAME = " CLAD2 8" , SOLID, PROPERTY= " ZIRC4 " , MCOND= " ZIRC2X") ENTITY (NAME= "CLAD29" , SOLID, PROPERTY= " ZIRC4 " , MCOND= "ZIRC2X") ENTITY (NAME=" CLAD210", SOLID, PROPERTY=" ZIRC4 ", MCOND="ZIRC2X") EN'TITY (NAME= "CLAD211" , SOLID, PROPERTY= " ZIRC4 ", MCOND= "ZIRC2X") ENTITY (NAME= "CLAD212", SOLID, PROPERTY= "ZIRC4" , MCOND= "ZIRC2X") ENTITY (NAME= "CLAD213", SOLID, PROPERTY = " ZIRC4 ", MCOND= "ZIRC2X") ENTITY (NAME= " CLAD2 14" , SOLID, PROPERTY= "ZIRC4 ", MCOND= "ZIRC2X") ENTITY (NAME= "CLAD2 15", SOLID, PROPERTY= "ZIRC4 " , MCOND= "ZIRC2X") ENTITY (NAME= "CIAD216", SOLID, PROPERTY="ZIRC4" , MCOND="ZIRC2X") EN'TITY (NAME= "CLAD217", SOLID, PROPERTY= " ZIRC4 ", MCOND=" ZIRC $2 X "$ ) ENTITY (NAME= "CLAD218", SOLID, PROPERTY=" ZIRC4 ", MCOND= "ZIRC2X") ENTITY (NAME = "CLAD219", SOLID, PROPERTY= "ZIRC4 ", MCOND= "ZIRC2X") ENTITY (NAME = "CLAD220", SOLID, PROPERTY = "ZIRC4 ", MCOND= "ZIRC2X") EN'TITY (NAME= " CLAD221" , SOLID, PROPERTY=" ZIRC4 " , MCOND= "ZIRC2X") ENTITY (NAME = "CLAD222 ", SOLID, PROPERTY = "ZIRC4" , MCOND="ZIRC2X") ENTITY (NAME= " CLAD223", SOLID, PROPERTY="ZIRC4" MCOND="ZIRC2X") ENTITY (NAME= "CLAD224", SOLID, PROPERTY= " ZIRC4 ", MCOND= "ZIRC2X") ENTITY (NAME= "CLAD225" , SOLID, PROPERTY=" ZIRC4 ", MCOND="ZIRC $2 X "$ ) ENTITY (NAME= "CLAD226" , SOLID, PROPERTY=" ZIRC4 " MCOND= "ZIRC2X") ENTITY (NAME= "CLAD227", SOLID, PROPERTY= " ZIRC4 " , MCOND= "ZIRC2X") ENTITY (NAME= "CLAD228", SOLID, PROPERTY="ZIRC4 ", MCOND="ZIRC2X") ENTITY (NAME= "CLAD229" SOLID, PROPERTY="ZIRC4 ", MCOND="ZIRC2X") ENTITY (NAME="CLAD230", SOLID, PROPERTY=" ZIRC4", MCOND="ZIRC2X") / / REMAINING ENTITIES - CONVECTION, RADIATION, PLOT, AND WALL, I

1

$/ \mathrm{ST}-\mathrm{MCO} \mathrm{GAP}$

I

ENTITY 〈NAME= "MCOSTRHS_PLOT", PLOT, ATTACH= "MCOST_GAP") ENTITY (NAME= "MCOSTRHS_RAD" , RADIATION, GREY, MEMSV=2, ATTACH="MCOST_GAP") ENTITY (NAME = "MCOSTLHS_PLOT", PLOT, ATTACH = "MCOST_GAP") ENTITY (NAME= "MCOSTLHS_RAD" , RADIATION, GREY, MEMSV=2, ATTACH= "MCOST_GAP") 1
HNF-4109, Rev. 0 Appendix A 
ENTITY (NAME= "STOD_RAD", PLOT, ATTACH="ST")

ENTITY (NAME= "STOD_PLOT" , PLOT, ATTACH= "ST")

ENTITY (NAME= "STOD_CONV", CONV, MCNV= "AIR140", ATTACH= "ST" )

ENTITY (NAME= "STID_PLOT", PLOT, ATTACH= "ST")

ENTITY (NAME= "STID_RAD" , RADIATION, GREY, MEMSV=1, ATTACH= "MCOST_GAP " , NATTACH="ST ")

1

/ MULTICANISTER OVERPACK - MCO

1

ENT ITY (NAME= "MCOOD_PLOT" , PLOT, ATTACH= "MCO")

ENTITY (NAME= "MCOOD_RAD" , RADIATION, GREY , MEMSV=3, ATTACH= "MCOST_GAP" , NATTACH= "MCO" ) ENTITY (NAME= "MCOID_PLOT", PLOT, ATPACH="MCO")

ENTITY (NAME= "MCOID_RAD1" , RADIATION, GREY , MEMSV=3, ATTACH= "FLON1 " , NATTACH= "MCO" ) ENTITY (NAME= "MCOID_RAD2", RADIATION, GREY, MEMSV=3, ATTACH= "FLOW2 " , NATTACH= "MCO")

1

/ MINIGAPS AND CENTRAL CROSS

/

ENTITY (NAME="VCROSS_RAD1" , RADIATION, GREY, MEMSV=3, ATTACH= "GAP2 " , NATTACH= "VCROSS") ENTITY (NAME= "VCROSS_RAD2 " , RADIATION, GREY, MEMSV=3, ATTACH= "GAP1" , NATTACH="VCROSS") ENTITY (NAME= "VCROSS_RAD3" , RADIATION, GREY, MEMSV=3, ATTACH= "GAP1 " , NATTACH= "VCROSS ") ENTITY (NAME= "VCROSS_RAD4 " , RADIATION, GREY, MEMSV=3, ATTACH= "GAP1 ", NATTACH="VCROSS") ENTITY (NAME= "VCROSS_RAD5" , RADIATION, GREY, MEMSV=3, ATTACH= "FLOW1 " , NATTACH="VCROSS" ENTITY (NAME="VCROSS_RAD6" , RADIATION, GREY, MEMSV=3, ATTACH= "FLOW1 " , NATTACH="MINI_GA ENTITY (NAME= "HCROSS_RAD1" , RADIATION, GREY, MEMSV=3, ATTACH= "GAP2" , NATTACH= "HCROSS") ENTITY (NAME= "HCROSS_RAD2" , RADIATION, GREY, MEMSV=3, ATTACH= "GAP3 " , NATTACH= "HCROSS" ) ENTITY (NAME=" HCROSS_RAD3" , RADIATION, GREY, MEMSV=3, ATTACH= "FLOW2 " NATTACH="HCROSS" ENTITY (NAME= "HCROSS_RAD4" , RADIATION, GREY, MEMSV=3, ATTACH= "FLOW2 " NATTACH= "MINI_GA /

$/$ BLANKET ASSEMBLIES - CANI AND CAN2

ENTITY (NAME=" CAN1OD_RAD1" , RADIATION, GREY, MEMSV=4, ATTACH= "GAP3" , NATTACH= "CAN11" , NATTACH $=$ "CAN1 2 ", NATTACH = "CAN14")

ENTITY (NAME= "CAN1OD_RAD2" , RADIATION, GREY, MEMSV=4, ATTACH= "FLOW2 " , NATTACH=" CAN12 ") ENTITY (NAME = "CAN1OD_RAD3 " , RADIATION, GREY, MEMSV=4, ATTACH= "ASMBLY_GAP" , NATTACH = "CA NATTACH $=$ "CAN13",NATTACH $=$ "CAN14")

ENTITY (NAME= "CAN1OD_RAD4" , RADIATION, GREY, MEMSV=4, ATTACH= "GAP1 " , NATTACH= "CAN14" ) ENTITY (NAME= "CAN1OD_PLOT" , PLOT, ATTACH= "GAP3 ", ATTACH = "FLOW2 " , ATTACH= "ASMBLY_GAP" , ATTACH = "GAP1 " NATTACH= "CAN1 1 " NATTACH= "CAN12 " NATTACH= "CAN13" , NATTACH $=$ "CA ENTITY (NAME= "CAN1 ID_PLOT" , PLOT, ATTACH= "FUEL1 " NATTACH= "CAN11" , NATTACH= "CAN12 " , NATTACH $=$ "CAN13", NATTACH $=$ "CAN1 $4 ")$

ENTITY (NAME = "CAN2OD_RAD1" , RADIATION, GREY, MEMSV=4, ATTACH= "ASMBLY_GAP" , NAT"TACH="CA NATTACH = "CAN2 $2 ", \mathrm{NATTACH}=$ "CAN24")

ENTITY (NAME= "CAN2OD_RAD2" , RADIATION, GREY , MEMSV=4, ATTACH= " FLOW2 " , NATTACH="CAN22") ENTITY (NAME= "CAN2OD_RAD3 " , RADIATION, GREY, MEMSV=4, ATTACH= "FLOW1 " , NATTACH= "CAN22 " , NATTACH $=$ "CAN23", NATTACH = "CAN24")

ENTITY (NAME = "CAN2OD_RAD4" , RADIATION, GREY, MEMSV=4, ATTACH= "GAP1" , NATTACH= "CAN24 ") ENTITY (NAME = "CAN2OD_PLOT", PLOT , ATTACH= "GAP1 ", ATTACH= "FLOW2 ", ATTACH= "ASMBLY_GAP" , ATTACH = "FLOW1" NATTACH = "CAN21", NATTACH = "CAN22" , NATTACH= "CAN23" , NATTACH= "C ENTITY (NAME= "CAN2 ID_PLOT" , PLOT, ATTACH= " FUEL2 " , NATTACH= "CAN21 " , NATTACH= " CAN22 " , NATTACH $=$ "CAN23", NATTACH $="$ CAN2 $4 "$ )

/

/ UNIFORM HEAT GENERATION THROUGHOUT ENTIRE VOLUME

$/$ PEAK-TO-AVERAGE AXIAL HEAT GENERATION RATIO = 1.55

1

\$ASSYHT $=7515.269412$

\$PAHEAT $=1.55$

/

I VOLUMETRIC HEAT GENERATION RATE - BASED ON ACTUAL VOLUME IN CAN1 AND CAN2 / EQUIVALENT TO 82.35 WATTS PER CAN OR 164.7 WATTS TOTAL FOR TWO CANS

/ HOWEVER FOR THIS 2D PROBLEM GIVEN THE ASSUMPTION OF A UNIT DEPTH OF ONE METER $/$ THE TOTAL POWER $=2 \times 82.35 \times(1.0 / 2.4527) \times$ PAHEAT $=104.0838$ WATTS

SOURCE (HEAT, ENTITY = "FUEL1", CONSTANT=\$ASSYHT $\$$ \$PAHEAT) SOURCE (HEAT , ENTITY = " FUEL2" , CONSTANT=\$ASSYHT * \$PAHEAT) / 
/

\section{WATER}

SPECIFICHEAT (SET= "WATER", CURVE=15, TEMPERATURE, SPATIAL)

$273.16 .288 .72,299.83,310.94,338.72,366.49,367.05$,

$367.60,394.27,422.05,477.60,533.16,588.72,810.94,1088.72$,

$4228.4,4186.6,4182.4,4182.4,4186.6,4228.4,4228.4$,

$4228.4,4270.3,4312.2,4521.5,4982.0,6321.7,6321.7,6321.7$

DENSITY (SET = "WATER" , CONSTANT $=994.7466)$

CONDUCTIVITY (SET= "WATER" , CURVE=15, TEMPERATURE, ISOTROPIC)

$273.16,288.72,299.83,310.94,338.72,366.49,367.05$,

$367.60,394.27,422.05,477.60,533.16,588.72,810.94,1088.72$,

$0.5521,0.5884,0.6109,0.6299,0.6628,0.6784,0.6784$,

$0.6784,0.6836,0.6836,0.6611,0.6040,0.5071,0.5071,0.5071$

$/$ AIR

SPECIFICHEAT ( SET="AIR ", CURVE=22, TEMPERATURE, SPATIAL)

$1.0,150.0,200.0,250.0,300.0,350.0,400.0,450.0,500.0,550.0,600.0$, $650.0,700.0,750.0,800.0,850.0,900.0,950.0,1000.0,1100.0,1200.0$,

10000.0 .

$1026.6,1009.9,1006.1,1005.3,1005.7,1009.0,1014.0,1020.7,1029.5$, $1039.2,1055.1,1063.5,1075.2,1085.6,1097.8,1109.5,1121.2,1132.1$,

$1141.7,1160.0,1179.0,1179.0$

DENSITY (SET= "AIR", CONSTANT=1.059779, TYP1, TEMPERATURE)

/ CONDUCTIVITY (SET= "AIR", CONSTANT=0.0347)

CONDUCTIVITY (SET=" AIR" , CURVE $=22$, TEMPERATURE, ISOTROPIC)

$1.0,150.0,200.0,250.0,300.0,350.0,400.0,450.0,500.0,550.0,600.0$. $650.0,700.0,750.0,800.0,850.0,900.0,950.0,1000.0,1100.0,1200.0$, 10000.0 .

$0.009246,0.013735,0.01809,0.02227,0.02624,0.03003,0.03365,0.03707$, $0.04038,0.04360,0.04659,0.04953,0.05230,0.05509,0.05779,0.06028$, $0.06279,0.06525,0.06752,0.07320,0.07820,0.07820$

CONDUCTIVITY (SET="AIR2X" , CURVE=22, TEMPERATURE, NONISOTROPIC)

$0.6995,1.0 \mathrm{E}-20,1.0 \mathrm{E}-20,1.0 \mathrm{E}-20,1.0,1.0 \mathrm{E}-20,1.0 \mathrm{E}-20,1.0 \mathrm{E}-20,1.0$ $1.0,150.0,200.0,250.0,300.0,350.0,400.0,450.0,500.0,550.0,600.0$. $650.0,700.0,750.0,800.0,850.0,900.0,950.0,1000.0,1100.0,1200.0$, 10000.0 ,

$0.009246,0.013735,0.01809,0.02227,0.02624,0.03003,0.03365,0.03707$, $0.04038,0.04360,0.04659,0.04953,0.05230,0.05509,0.05779,0.06028$. $0.06279,0.06525,0.06752,0.07320,0.07820,0.07820$

CONDUCTIVITY (SET= "AIR3X", CURVE=22, TEMPERATURE , NONISOTROPIC)

$0.5073 .1 .0 \mathrm{E}-20,1.0 \mathrm{E}-20,1.0 \mathrm{E}-20,1.0,1.0 \mathrm{E}-20,1.0 \mathrm{E}-20,1.0 \mathrm{E}-20,1.0$ $1.0,150.0,200.0,250.0,300.0,350.0,400.0,450.0,500.0,550.0,600.0$. $650.0,700.0,750.0,800.0,850.0,900.0,950.0,1000.0,1100.0,1200.0$, 10000.0

$0.009246,0.013735,0.01809,0.02227,0.02624,0.03003,0.03365,0.03707$, $0.04038,0.04360,0.04659,0.04953,0.05230,0.05509,0.05779,0.06028$. $0.06279,0.06525,0.06752,0.07320,0.07820,0.07820$ VISCOSITY (SET="AIR", CURVE $=22$, TEMPERATURE, TWO-EQUATION)

$1.0,150.0,200.0,250.0,300.0,350.0,400.0,450.0,500.0,550.0,600.0$. $650.0,700.0,750.0,800.0,850.0,900.0,950.0,1000.0,1100.0,1200.0$, 10000.0,

$0.6924 \mathrm{E}-5,1.0283 \mathrm{E}-5,1.3289 \mathrm{E}-5,1.5990 \mathrm{E}-5,1.8462 \mathrm{E}-5,2.0750 \mathrm{E}-5,2.2860 \mathrm{E}-5$, $2.4840 \mathrm{E}-5,2.6710 \mathrm{E}-5,2.8480 \mathrm{E}-5,3.0180 \mathrm{E}-5,3.1770 \mathrm{E}-5,3.3320 \mathrm{E}-5,3.4810 \mathrm{E}-5$, $3.6250 \mathrm{E}-5,3.7650 \mathrm{E}-5,3.8990 \mathrm{E}-5,4.0230 \mathrm{E}-5,4.1520 \mathrm{E}-5,4.4400 \mathrm{E}-5,4.6900 \mathrm{E}-5$, $4.6900 \mathrm{E}-5$

VOLUMEXPANSION (SET = "AIR", CURVE=22, TEMEERATURE, GRAVITY $=9.8066352$, THETA $=0$, PHI $=0$, REFTEMP $=333.15$ )

$1.0,150.0,200.0,250.0,298,15,350.0,400.0,450.0,500.0,550.0,600.0$, $650.0,700.0,750.0,800.0,850.0,900.0,950.0,1000.0,1100.0,1200.0,10000.0$, $1 \mathrm{E}-2,6.6667 \mathrm{E}-3,5 \mathrm{E}-3,4 \mathrm{E}-3,3.3333 \mathrm{E}-3,2.8571 \mathrm{E}-3,2.5 \mathrm{E}-3,2.2222 \mathrm{E}-3,2 \mathrm{E}-3$,

$1.8182 \mathrm{E}-3,1.6667 \mathrm{E}-3,1.5385 \mathrm{E}-3,1.4286 \mathrm{E}-3,1.3333 \mathrm{E}-3,1.25 \mathrm{E}-3,1.1765 \mathrm{E}-3$, 1. $1111 \mathrm{E}-3,1.0526 \mathrm{E}-3,1 \mathrm{E}-3,9.0909 \mathrm{E}-4,8.3333 \mathrm{E}-4.1 .0 \mathrm{E}-4$

DIFFUSIVITY (SET = "AIR", CURVE $=21$, TEMPERATURE, I SOTROPIC)

$-1.0 \mathrm{E}+6,255.2,271.9,288.6,299.7,310.8,338.6,366.3,394.1,421.9,477.4,533.0$, $588.6,699.7,810.8,1088.6,2000,3000,5000,10000,1.0 \mathrm{E}+6$.

$1.5850 \mathrm{E}-5,1.5850 \mathrm{E}-5,1.7430 \mathrm{E}-5,1.9062 \mathrm{E}-5,2.0172 \mathrm{E}-5,2.1302 \mathrm{E}-5,2.4224 \mathrm{E}-5$, 
$2.7256 \mathrm{E}-5,3.0416 \mathrm{E}-5,3.3692 \mathrm{E}-5,4.0554 \mathrm{E}-5,4.7840 \mathrm{E}-5,5.5519 \mathrm{E}-5,7.1959 \mathrm{E}-5$ Appendix A $8.9759 \mathrm{E}-5,1.3964 \mathrm{E}-4,3.4774 \mathrm{E}-4,6.3883 \mathrm{E}-4,1.3746 \mathrm{E}-3,3.8878 \mathrm{E}-3,7.7756 \mathrm{E}-3$

\section{/ HELIUM}

SPECIFICHEAT (SET = "HE" , CONSTANT $=5200.0$ )

DENSITY ( SET = "HE", CONSTANT=0.146438, TYP1, TEMPERATURE)

/CONDUCTIVITY (SET $=$ "HE" , CONSTANT=0.18675)

CONDUCTIVITY ( $S E T="$ HE ", CURVE $=24$, TEMPERATURE, ISOTROPIC)

$100.0,200.0,298.15,400.0,500.0,600.0,700.0,800.0,900.0,1000.0,1200.0$,

$1400.0,1500.0,1600.0,1700.0,1800.0,1900.0,2000.0,2500.0,3000.0$,

$3500.0,4000.0,4500.0,5000.0$,

$0.073,0.1151,0.1499,0.1795,0.2114,0.2470,0.278,0.307,0.335,0.363,0.416,0.469$, $0.494,0.521,0.545,0.570,0.596,0.620,0.739,0.851,0.958,1.064,1.169,1.271$

CONDUCTIVITY (SET = " HE2X", CURVE $=24$, TEMPERATURE, NONISOTROPIC)

$0.6995,1.0 \mathrm{E}-20,1.0 \mathrm{E}-20,1.0 \mathrm{E}-20,1.0,1.0 \mathrm{E}-20,1.0 \mathrm{E}-20,1.0 \mathrm{E}-20,1.0$

$100.0,200.0,298.15,400.0,500.0,600.0,700.0,800.0,900.0,1000.0,1200.0$.

$1400.0,1500.0,1600.0,1700.0,1800.0,1900.0,2000.0,2500.0,3000.0$,

$3500.0,4000.0,4500.0,5000.0$,

$0.073,0.1151,0.1499,0.1795,0.2114,0.2470,0.278,0.307,0.335,0.363,0.416,0.469$,

$0.494,0.521,0.545,0.570,0.596,0.620,0.739,0.851,0.958,1.064,1.169,1.271$

CONDUCTIVITY $($ SET $=$ "HE3X", CURVE $=24$, TEMPERATURE, NONISOTROPIC $)$

$0.5073,1.0 \mathrm{E}-20,1.0 \mathrm{E}-20,1.0 \mathrm{E}-20,1.0,1.0 \mathrm{E}-20,1.0 \mathrm{E}-20,1.0 \mathrm{E}-20,1.0$

$100.0,200.0,298.15,400,0,500.0,600.0,700.0,800.0,900.0,1000.0,1200.0$,

$1400.0,1500.0,1600.0,1700.0,1800.0,1900.0,2000.0,2500.0,3000.0$,

$3500.0,4000.0,4500.0,5000.0$

$0.073,0.1151,0.1499,0.1795,0.2114,0.2470,0.278,0.307,0.335,0.363,0.416,0.469$,

$0.494,0.521,0.545,0.570,0.596,0.620,0.739,0.851,0.958,1.064,1.169,1.271$

VISCOSITY (SET = "HE" , CURVE=22, TEMPERATURE, TWO-EQUATION)

$100.0,200.0,298.15,400.0,500.0,600.0,700.0,800.0,900.0,1000.0$,

$1100.0,1200.0,1298.15,1400.0,1500.0,1600.0,1700.0,1800.0,2000.0$,

$2200.0,2400.0,5000.0$,

$9.63 E-6,14.97 E-6,19.89 E-6,24.28 E-6,28.27 E-6,31.99 E-6,35.49 E-6,38.84 E-6$,

$42.01 \mathrm{E}-6,45.04 \mathrm{E}-6,48.0 \mathrm{E}-6,50.8 \mathrm{E}-6,53.5 \mathrm{E}-6,56.1 \mathrm{E}-6,58.6 \mathrm{E}-6,61.0 \mathrm{E}-6$,

$63.4 \mathrm{E}-6,65.7 \mathrm{E}-6,70.0 \mathrm{E}-6,74.2 \mathrm{E}-6,78.3 \mathrm{E}-6,78.3 \mathrm{E}-6$

VISCOSITY ( SET $=$ "HEPOROUS" , CURVE $=22$, TEMPERATURE , TWO-EQUATION)

$100.0,200.0,298.15,400.0,500.0,600.0,700.0,800.0,900.0,1000.0$,

$1100.0,1200.0,1298.15,1400.0,1500.0,1600.0,1700.0,1800.0,2000.0$,

$2200.0,2400.0,5000.0$,

$9.63 \mathrm{E}-8,14.97 \mathrm{E}-8,19.89 \mathrm{E}-8,24.28 \mathrm{E}-8,28.27 \mathrm{E}-8,31.99 \mathrm{E}-8,35.49 \mathrm{E}-8,38.84 \mathrm{E}-8$,

$42.01 \mathrm{E}-8,45.04 \mathrm{E}-8,48.0 \mathrm{E}-8,50.8 \mathrm{E}-8,53.5 \mathrm{E}-8,56.1 \mathrm{E}-8,58.6 \mathrm{E}-8,61.0 \mathrm{E}-8$,

$63.4 \mathrm{E}-8,65.7 \mathrm{E}-8,70.0 \mathrm{E}-8,74.2 \mathrm{E}-8,78.3 \mathrm{E}-8,78.3 \mathrm{E}-8$

VOLUMEXPANSION ( SET $=$ "HE" , CURVE $=22$, TEMPERATURE, GRAVITY $=9.8066352$,

$$
\text { THETA }=0, \text { PHI }=0, \text { REFTEMP }=333.15 \text { ) }
$$

$-1.0 \mathrm{E}+6,150.0,200.0,250.0,298.15,350.0,400.0,450.0,500.0,550.0,600.0$,

$650.0,700.0,750.0,800.0,850.0,900.0,950.0,1000.0,1100.0,1200.0,10000.0$,

$1 \mathrm{E}-2,6.6667 \mathrm{E}-3,5 \mathrm{E}-3,4 \mathrm{E}-3,3.3333 \mathrm{E}-3,2.8571 \mathrm{E}-3,2.5 \mathrm{E}-3,2.2222 \mathrm{E}-3,2 \mathrm{E}-3$,

$1.8182 \mathrm{E}-3,1.6667 \mathrm{E}-3,1.5385 \mathrm{E}-3,1.4286 \mathrm{E}-3,1.3333 \mathrm{E}-3,1.25 \mathrm{E}-3,1.1765 \mathrm{E}-3$,

$1.1111 \mathrm{E}-3,1.0526 \mathrm{E}-3,1 \mathrm{E}-3,9.0909 \mathrm{E}-4,8.3333 \mathrm{E}-4,1.0 \mathrm{E}-4$

DIFFUSIVITY (SET = "HE" , CURVE=21, TEMPERATURE, ISOTROPIC)

$-1.0 \mathrm{E}+6,255.2,271.9,288.6,299.7,310.8,338.6,366.3,394.1,421.9,477.4,533.0$,

$588.6,699.7,810.8,1088.6,2000,3000,5000,10000,1.0 \mathrm{E}+6$.

$1.5850 \mathrm{E}-5,1.5850 \mathrm{E}-5,1.7430 \mathrm{E}-5,1.9062 \mathrm{E}-5,2.0172 \mathrm{E}-5,2.1302 \mathrm{E}-5,2.4224 \mathrm{E}-5$,

$2.7256 \mathrm{E}-5,3.0416 \mathrm{E}-5,3.3692 \mathrm{E}-5,4.0554 \mathrm{E}-5,4.7840 \mathrm{E}-5,5.5519 \mathrm{E}-5,7.1959 \mathrm{E}-5$,

$8.9759 \mathrm{E}-5,1.3964 \mathrm{E}-4,3.4774 \mathrm{E}-4,6.3883 \mathrm{E}-4,1.3746 \mathrm{E}-3,3.8878 \mathrm{E}-3,7.7756 \mathrm{E}-3$

$/$ ARGON

SPECIFICHEAT ( SET = "AR" , CONSTANT $=520.4$ )

DENSITY (SET = "AR" , CONSTANT $=1.46138)$

/CONDUCTIVITY (SET $=$ "AR", CONSTANT $=0.023385$ )

CONDUCTIVITY (SET = "AR", CURVE=20, TEMPERATURE, ISOTROPIC)

$100.0,200.0,298.15,400.0,500.0,600.0,700.0,800.0,900.0,1000.0$,

$1100.0,1200.0,1298.15,1400.0,1500.0,1600.0,1700.0,1800.0$,

$1900.0,2000.0$,

$0.00652,0.01244,0.01772,0.02233,0.02638,0.0301,0.0336,0.0369,0.0398$,

$0.0427,0.0454,0.0481,0.0508,0.0535,0.0561,0.0588,0.0615,0.0641,0.0667$,

0.0692

VISCOSITY (SET= "AR", CURVE=22, TEMPERATURE, TWO-EQUATION)

$-10000.0,200.0,298.15,400.0,500.0,600.0,700.0,800.0,900.0,1000.0$, 
$1100.0,1200.0,1298.15,1400.0,1500.0,1600.0,1700.0,1800.0$,

$1900.0,2000.0,2200.0,10000.0$

$8.34 \mathrm{E}-6,16.01 \mathrm{E}-6,22.72 \mathrm{E}-6,28.52 \mathrm{E}-6,33.6 \mathrm{E}-6,38.3 \mathrm{E}-6,42.5 \mathrm{E}-6,46.4 \mathrm{E}-6$,

$50.1 \mathrm{E}-6,53.5 \mathrm{E}-6,56.8 \mathrm{E}-6,59.9 \mathrm{E}-6,62.8 \mathrm{E}-6,65.6 \mathrm{E}-6,68.4 \mathrm{E}-6,71.0 \mathrm{E}-6$,

$73.5 \mathrm{E}-6,76.0 \mathrm{E}-6,78.4 \mathrm{E}-6,80.7 \mathrm{E}-6,85.1 \mathrm{E}-6,85.1 \mathrm{E}-6$

VISCOSITY (SET="ARPOROUS", CURVE=22, TEMPERATURE, TWO-EQUATION)

$-10000.0,200.0,298,15,400.0,500.0,600.0,700.0,800.0,900.0,1000.0$,

$1100.0,1200.0,1298.15,1400.0,1500.0,1600.0,1700.0,1800.0$.

$1900.0,2000.0,2200.0,10000.0$

$8.34 \mathrm{E}-8,16.01 \mathrm{E}-8,22.72 \mathrm{E}-8,28.52 \mathrm{E}-8,33.6 \mathrm{E}-8,38.3 \mathrm{E}-8,42.5 \mathrm{E}-8,46.4 \mathrm{E}-8$,

$50.1 \mathrm{E}-8,53.5 \mathrm{E}-8,56.8 \mathrm{E}-8,59.9 \mathrm{E}-8,62.8 \mathrm{E}-8,65.6 \mathrm{E}-8,68.4 \mathrm{E}-8,71.0 \mathrm{E}-8$.

$73.5 \mathrm{E}-8,76.0 \mathrm{E}-8,78,4 \mathrm{E}-8,80.7 \mathrm{E}-8,85.1 \mathrm{E}-8,85.1 \mathrm{E}-8$

VOLUMEXPANSION (SET = "AR", CURVE=22, TEMPERATURE, GRAVITY=9.8066352,

$$
\text { THETA }=0, \text { PHI =0, REFTEMP }=333.15 \text { ) }
$$

$-1.0 E+6,150.0,200.0,250.0,298.15,350.0,400.0,450.0,500.0,550.0,600.0$, $650,0,700.0,750.0,800.0,850.0,900.0,950.0,1000.0,1100.0,1200.0,10000.0$,

$1 \mathrm{E}-2,6.6667 \mathrm{E}-3,5 \mathrm{E}-3,4 \mathrm{E}-3,3.3333 \mathrm{E}-3,2.8571 \mathrm{E}-3,2.5 \mathrm{E}-3,2.2222 \mathrm{E}-3,2 \mathrm{E}-3$,

$1.8182 \mathrm{E}-3,1.6667 \mathrm{E}-3,1.5385 \mathrm{E}-3,1.4286 \mathrm{E}-3,1.3333 \mathrm{E}-3,1.25 \mathrm{E}-3,1.1765 \mathrm{E}-3$,

$1.1111 \mathrm{E}-3,1.0526 \mathrm{E}-3,1 \mathrm{E}-3,9.0909 \mathrm{E}-4,8.3333 \mathrm{E}-4,1.0 \mathrm{E}-4$

DIFFUSIVITY (SET= "AR", CURVE=21, TEMPERATURE, ISOTROPIC)

$-1.0 E+6,255.2,271.9,288.6,299.7,310.8,338.6,366.3,394.1,421.9,477.4,533.0$,

$588.6,699.7,810.8,1088.6,2000,3000,5000,10000,1.0 \pm+6$,

1.5850E-5,1.5850E-5,1.7430E-5,1.9062E-5,2.0172E-5,2.1302E-5,2.4224E-5,

$2.7256 \mathrm{E}-5,3.0416 \mathrm{E}-5,3.3692 \mathrm{E}-5,4.0554 \mathrm{E}-5,4.7840 \mathrm{E}-5.5 .5519 \mathrm{E}-5,7.1959 \mathrm{E}-5$.

$8.9759 \mathrm{E}-5,1.3964 \mathrm{E}-4,3.4774 \mathrm{E}-4,6.3883 \mathrm{E}-4,1.3746 \mathrm{E}-3,3.8878 \mathrm{E}-3,7.7756 \mathrm{E}-3$

\section{/ NITROGEN}

SPECIFICHEAT (SET= "N2 ", CURVE=14, TEMPERATURE, SPATIAL)

$100.0,200.0,298.15,400.0,500.0,600.0,700.0,800.0,900.0$,

$1000.0,1100.0,1200.0,1298,15,1366.0$,

$1040.0,1040.0,1040.0,1045.0,1057.0,1075.0,1098.0,1122.0,1146.0$,

$1168.0,1187.0,1205.0,1220.0,1229.0$

DENSITY (SET = "N2", CONSTANT=1.04653)

/CONDUCTIVITY (SET="N2", CONSTANT=0.0340725)

CONDUCTIVITY (SET= "N2", CURVE=22, TEMPERATURE, ISOTROPIC)

$100.0,200.0,298.15,400.0,500.0,600.0,700.0,800.0,900.0,1000.0$,

$1100.0,1200.0,1298.15,1400.0,1500.0,1600.0,1700.0,1800.0$,

$1900.0,2000.0,2500.0,3000.0$,

$0.00941,0.01826,0.02589,0.03252,0.03864,0.0441,0.0493,0.0541,0.0587$,

$0.0631,0.0672,0.0713,0.0754,0.0797,0.0842,0.0893,0.0950,0.1013$,

$0.1080,0.1146,0.1406,0.1640$

VISCOSTTY (SET = "N2", CURVE=21, TEMPERATURE, TWO-EQUATION)

$100.0,200.0,298.15,400.0,500.0,600.0,700.0,800.0,900.0,1000.0$,

$1100.0,1200.0,1298.15,1400.0,1500.0,1600.0,1700.0,1800.0$,

$1900.0,2000.0,2200.0$,

$6.87 \mathrm{E}-6,12.86 \mathrm{E}-6,17.86 \mathrm{E}-6,22.14 \mathrm{E}-6,25.9 \mathrm{E}-6,29.27 \mathrm{E}-6,32.35 \mathrm{E}-6$,

$35.2 E-6,37.86 E-6,40.36 E-6,42.7 E-6,45.0 E-6,47.1 E-6,49.2 E-6$,

$51.2 \mathrm{E}-6,53.1 \mathrm{E}-6,54.9 \mathrm{E}-6,56.7 \mathrm{E}-6,58.5 \mathrm{E}-6,60.1 \mathrm{E}-6,63.4 \mathrm{E}-6$

VISCOSITY (SET= "N2 POROUS", CURVE=21, TEMPERATURE, TWO-EQUATION)

$100.0,200.0,298.15,400.0,500.0,600.0,700.0,800.0,900.0,1000.0$,

$1100.0,1200.0,1298.15,1400.0,1500.0,1600.0,1700.0,1800.0$,

$1900.0,2000.0,2200.0$,

$6.87 \mathrm{E}-8,12.86 \mathrm{E}-8,17.86 \mathrm{E}-8,22.14 \mathrm{E}-8,25.9 \mathrm{E}-8,29.27 \mathrm{E}-8,32.35 \mathrm{E}-8$,

$35.2 \mathrm{E}-8,37.86 \mathrm{E}-8,40.36 \mathrm{E}-8,42.7 \mathrm{E}-8,45.0 \mathrm{E}-8,47.1 \mathrm{E}-8,49.2 \mathrm{E}-8$,

$51.2 \mathrm{E}-8,53.1 \mathrm{E}-8,54.9 \mathrm{E}-8,56.7 \mathrm{E}-8,58.5 \mathrm{E}-8,60.1 \mathrm{E}-8,63.4 \mathrm{E}-8$

VOLUMEXPANSION ( SET $=$ "N2" , CURVE=22, TEMPERATURE, GRAVITY=9.8066352,

THETA $=0$, PHI $=0$, REFTEMP $=333.15$ )

$-1.0 \mathrm{E}+6,150.0,200.0,250.0,298.15,350.0,400.0,450.0,500.0,550.0,600.0$, $650.0,700.0,750.0,800.0,850.0,900.0,950.0,1000.0,1100.0,1200.0,10000.0$, $1 \mathrm{E}-2,6.6667 \mathrm{E}-3,5 \mathrm{E}-3,4 \mathrm{E}-3,3.3333 \mathrm{E}-3,2.8571 \mathrm{E}-3,2.5 \mathrm{E}-3,2.2222 \mathrm{E}-3,2 \mathrm{E}-3$,

1. $8182 \mathrm{E}-3,1.6667 \mathrm{E}-3,1.5385 \mathrm{E}-3,1.4286 \mathrm{E}-3,1.3333 \mathrm{E}-3,1.25 \mathrm{E}-3,1.1765 \mathrm{E}-3$,

1. $1111 \mathrm{E}-3,1.0526 \mathrm{E}-3,1 \mathrm{E}-3,9.0909 \mathrm{E}-4,8.3333 \mathrm{E}-4,1.0 \mathrm{E}-4$

DIFFUSIVITY (SET = " N2 ", CURVE=21, TEMPERATURE, ISOTROPIC)

$-1 . \mathrm{OE}+6,255.2,271.9,288.6,299.7,310.8,338.6,366.3,394.1,421.9,477.4,533.0$,

$588.6,699.7,810.8,1088.6,2000,3000,5000,10000,1.0 \mathrm{E}+6$,

$1.5850 \mathrm{E}-5,1.5850 \mathrm{E}-5,1.7430 \mathrm{E}-5,1.9062 \mathrm{E}-5,2.0172 \mathrm{E}-5,2.1302 \mathrm{E}-5,2.4224 \mathrm{E}-5$,

$2.7256 \mathrm{E}-5,3.0416 \mathrm{E}-5,3.3692 \mathrm{E}-5,4.0554 \mathrm{E}-5,4.7840 \mathrm{E}-5,5.5519 \mathrm{E}-5,7.1959 \mathrm{E}-5$, 
$8.9759 \mathrm{E}-5,1.3964 \mathrm{E}-4,3.4774 \mathrm{E}-4,6.3883 \mathrm{E}-4,1.3746 \mathrm{E}-3,3.8878 \mathrm{E}-3.7 .7756 \mathrm{E}-3$

/ OXYGEN

SPECIFICHEAT (SET= "O2", CURVE=9, TEMPERATURE, SPATIAL)

$150.0,200.0,250.0,298.15,350.0,400.0,450.0,500.0,550.0$,

$917.8,913.1,915.7,920.3,929.1,942.0,956.7,972.2,988.1$

DENSITY (SET="O2", CONSTANT=1.17645, TYP1, TEMPERATURE)

CONDUCTIVITY ( SET = "O2", CURVE=9, TEMPERATURE, ISOTROPIC)

$150.0,200.0,250.0,298.15,350.0,400.0,450.0,500.0,550.0$,

$0.01367,0.01824,0.02259,0.02676,0.03070,0.03461$,

$0.03828,0.04173,0.04517$

VISCOSITY ( SET = " O2 " , CURVE=9, TEMPERATURE)

$150,200,250,300,350,400,450,500,550$,

$11.49 \mathrm{E}-6,14.85 \mathrm{E}-6,17.87 \mathrm{E}-6,20.63 \mathrm{E}-6,23.16 \mathrm{E}-6,25.54 \mathrm{E}-6,27.27 \mathrm{E}-6$,

$29.91 \mathrm{E}-6,31.97 \mathrm{E}-6$

VOLUMEXPANSION (SET="O2", CURVE=21, TEMPERATURE, GRAVITY=9.8066352, THETA $=0$, PHI $=0$, REFTEMP $=333.15$ )

$100.0,150.0,200.0,250.0,300.0,350.0,400.0,450.0,500.0,550.0,600.0$,

$650.0,700.0,750.0,800.0,850.0,900.0,950.0,1000.0,1100.0,1200.0$,

$1 \mathrm{E}-2,6.6667 \mathrm{E}-3,5 \mathrm{E}-3,4 \mathrm{E}-3,3.3333 \mathrm{E}-3,2.8571 \mathrm{E}-3,2.5 \mathrm{E}-3,2.2222 \mathrm{E}-3,2 \mathrm{E}-3$,

$1.8182 \mathrm{E}-3,1.6667 \mathrm{E}-3,1.5385 \mathrm{E}-3,1.4286 \mathrm{E}-3,1.3333 \mathrm{E}-3,1.25 \mathrm{E}-3,1.1765 \mathrm{E}-3$,

$1.1111 \mathrm{E}-3,1.0526 \mathrm{E}-3,1 \mathrm{E}-3,9.0909 \mathrm{E}-4,8.3333 \mathrm{E}-4$

DIFFUSIVITY (SET" "O2", CURVE=21, TEMPERATURE, ISOTROPIC)

$-1.0 \mathrm{E}+6,255.2,271.9,288.6,299.7,310.8,338.6,366.3,394.1,421.9,477.4,533.0$,

$588.6,699.7,810.8,1088.6,2000,3000,5000,10000,1.0 \mathrm{E}+6$.

$1.5850 \mathrm{E}-5,1.5850 \mathrm{E}-5,1.7430 \mathrm{E}-5,1.9062 \mathrm{E}-5,2.0172 \mathrm{E}-5,2.1302 \mathrm{E}-5,2.4224 \mathrm{E}-5$,

$2.7256 \mathrm{E}-5,3.0416 \mathrm{E}-5,3.3692 \mathrm{E}-5,4.0554 \mathrm{E}-5,4.7840 \mathrm{E}-5,5.5519 \mathrm{E}-5,7.1959 \mathrm{E}-5$,

$8.9759 E-5,1.3964 E-4,3.4774 E-4,6.3883 E-4,1.3746 E-3,3.8878 E-3,7.7756 E-3$

$/$ HYDROGEN

SPECIFICHEAT (SET $=$ "H2 ", CURVE $=13$, TEMPERATURE, SPATIAL)

$150.0,200.0,250.0,300.0,350.0,400.0,450.0,500.0,550,0,600.0,700.0$,

$800.0,900.0$

$12602.0,13450.0,14059.0,14314.0,14436.0,14491.0,14499.0,14507.0$,

$14532.0,14537.0,14574.0,14675.0,14821.0$

DENSITY (SET $=$ "H2 ", CONSTANT $=0.07409953)$

CONDUCTIVITY (SET= " H2 ", CURVE=13, TEMPERATURE, ISOTROPIC)

$150.0,200.0,250.0,300.0,350.0,400.0,450.0,500.0,550,0,600.0,700.0$,

$800.0,900.0$

$0.0981,0.1282,0.1561,0.181,0.206,0.228,0.251,0.272,0.292,0.315$,

$0.351,0.384,0.412$

I UMETAL

SPECIFICHEAT (SET= "UMETAL " , CURVE=15, TEMPERATURE, SPATIAL)

$100.00,273.16,373.16,473.16,573.16,673.16,773.16$,

$873.16,939.16,940.16,1049.16,1050.16,1403.16,1773.16,10000.0$,

$114.0843,115.1309,122.4574,131.8772,142.3437,153.6474,168.5098$,

$188.3960,206.8170,178.7669,178.7669,160.7646,160.7646,160.7646,160.7646$

DENSITY (SET = "UMETAL" , CONSTANT=19037.5, GASCONSTANT=19037.5)

/CONDUCTIVITY (SET= "UMETAL", CONSTANT=27.9587)

CONDUCTIVITY (SET = " UMETAL ", CURVE=15, TEMPERATURE, ISOTROPIC)

$100.00,273.16,373.16,473.16,573.16,673.16,773.16$,

$873.16,939.16,940.16,1049.16,1050.16,1403.16,1773.16,10000.0$,

$26.7968,26.9015,26.9015,29.0159,30.9838,32.9726,35.0033$,

$37.8924,39.1485,39.1485,41.4513,41.4513,50.2440,50.2440,50.2440$

/ ZIRC4

SPECIFICHEAT (SET = " ZIRC4 ", CURVE=15, TEMPERATURE, SPATIAL)

$100.00,273.16,310.94,366.49,422.05,477.60,533.16$,

$588.72,644.27,699,83,755.38,810.94,922.05,1088.72,2000.0$,

$284.6873,284.6873,288.8739,293.0605,301.4336,305.2022,309.8068$,

$318.1800,322.3665,330.7397,334.9263,341.2061,360.0457,376.7921$,

376.7921

DENSITY (SET= "ZIRC4 ", CONSTANT $=6550.0)$

CONDUCTIVITY (SET=" ZIRC4", CURVE=9, TEMPERATURE, ISOTROPIC)

$273.16,373.16,473.16,573.16,673.16,773.16,873.16,973.16,1073.16$,

$12.3517,13.3984,14.4452,15.6175,17.0411,18.4228,19.8883,21.5212$,

23.0285

CONDUCTIVITY (SET= " ZIRC2X" , CURVE=9, TEMPERATURE, NONISOTROPIC)

$1.3191,1.0 \mathrm{E}-20,1.0 \mathrm{E}-20,1.0 \mathrm{E}-20,1,0,1.0 \mathrm{E}-20,1.0 \mathrm{E}-20,1.0 \mathrm{E}-20,1.0$ 
$273.16,373.16,473.16,573.16,673.16,773.16,873.16,973.16,1073.16$,

$12.3517,13.3984,14.4452,15.6175,17.0411,18.4228,19.8883,21.5212$,

23.0285

/ UO2

SPECIFICHEAT ( SET = "UO2" , CURVE $=14$, TEMPERATURE, SPATIAL)

$-1.0 \mathrm{E}+6,298.0,366.33,505.22,644.11,783.0,921.89$,

$1060.8,1199.7,1338.6,1477.4,1616.3,1755.2,1894.1$,

$235.62,235.62,256.80,280.36,293.26,301.99,308.78$,

$314.56,319.77,324.72,329.73,335.42,342.85,353.69$

DENSITY ( SET $=$ " UO2 " , CONSTANT $=10970.0$ )

CONDUCTIVITY (SET $=$ " UO2" , CURVE $=14$, TEMPERATURE, ISOTROPIC)

$-1 . \mathrm{OE}+6,298.0,333.33,444.44,555.56,666.67,777.78,888.89,1000.0$,

$1222.2,1444.44,1666.7,1888.9,2000.0$,

$8.2704,8.2704,7.3417,6.7192,5.8508,5.1601,4.5985,4.1337,3.7434,3.1276$,

$2.6761,2.3638,2.2030,2.1908$

CONDUCTIVITY (SET = "UO2X" , CURVE $=14$, TEMPERATURE, NONISOTROPIC $)$

$0.9233,1.0 \mathrm{E}-20,1 . \mathrm{OE}-20,1.0 \mathrm{E}-20,1.0,1 . \mathrm{OE}-20,1.0 \mathrm{E}-20,1.0 \mathrm{E}-20,1.0$

$-\mathrm{I} .0 \mathrm{E}+6,298.0,333.33,444.44,555.56,666.67,777.78,888.89,1000.0$,

$1222.2,1444.44,1666.7,1888.9,2000.0$,

$8.2704 .8 .2704,7.3417,6.7192,5.8508,5.1601,4.5985,4.1337,3.7434,3.1276$,

$2.6761,2.3638,2.2030,2.1908$

/ PUO2 POWDER AT 2.5 GM/CM3

SPECIFICHEAT (SET = "PUO2", CURVE $=20$, TEMPERATURE, SPATIAL)

$100.0,200.0,300.0,325.0,350.0,375.0,400.0,450.0,500.0,550.0$,

$600.0,650.0,700.0,750.0,800.0,900.0,1000.0,1200.0,1400.0,2000.0$,

$258.64,258.64,258,64,271.23,281.25,289.34,295.98,306.13,313.44$,

$318.88,323.07,324.27,329.00,331.16,332.96,335.78,337.89,340.86$,

$342.90,342.90$

DENSITY (SET $=$ " PUO2 $"$, CONSTANT $=2500.0)$

CONDUCTIVITY (SET = " PUO2" , CONSTANT $=0.282362193)$

$/ \mathrm{AL}$

SPECIFICHEAT (SET $=$ " AL " , CONSTANT $=937.7936$ )

DENSITY (SE'T = "AL", CONSTANT $=2700.7129)$

CONDUCTIVITY (SET $=$ "AL" , CURVE=6, TEMPERATURE, ISOTROPIC)

$273.16,293.16,373.16,573.16,699.83,1088.72,228.4449,228.4449,228.4449$, $230.1755,230.1755,230.1755$

I SS304

SPECIFICHEAT (SET $="$ SS $304 "$, CURVE $=18$, TEMPERATURE, SPATIAL)

$-1.0 \mathrm{E}+6,294.16,311.16,366.16,422.16,477.16,533.16,589.16,644.16$,

$700.16,755.16,811.16,866.16,922.16,977.16,1033.16,1144.16,10000.0$,

$477.6,477.6,483.9,503.1,519.1,533.5,545.2,555.2,563.8,571.3$,

$578.0,584.3,590.5,597.0,604.1,612.2,632.7,632.7$

DENSITY (SET $="$ SS304", CONSTANT $=8045.0)$

/CONDUCTIVITY (SET= "SS304", CONSTANT=17.00)

CONDUCTIVITY (SET=" SS304", CURVE=18, TEMPERATURE, ISOTROPIC)

$-1.0 \mathrm{E}+6,294.16,311.16,366.16,422.16,477.16,533.16,589.16,644.16$,

$700.16,755.16,811.16,866.16,922.16,977.16,1033.16,1144.16,10000.0$,

$14.83,14.83,15.12,16.08,17.00,17.90,18.76,19.60,20.42,21.22$,

$22.00,22.77,23.53,24.27,25.01,25.74,27.20,27.20$

/ SS 316

SPECIFICHEAT (SET=" SS316", CURVE=14, TEMPERATURE, SPATIAL)

$1.0,294.27,310.94,366.49,422.05,477.60,533.16$,

$588.72,644.27,699.83,810.94,922.05,1033.16,1144.27$,

$465.6,465.6,472.3,492.4,509.7,524.3,536.6$,

$547.1,556.1,563.9,577.6,590.9,606.9,628.4$

DENSITY (SET $=$ "SS316", CONSTANT $=7962.0)$

CONDUCTIVITY (SET=" SS316", CURVE=14, TEMPERATURE, ISOTROPIC)

$1.0,294.27,310.94,366.49,422.05,477.60,533.16$,

$588.72,644.27,699.83,810.94,922.05,1033.16,1144.27$,

$13.36,13.36,13.54,14.58,15.51,16.41,17.31$,

$18.18,19.04,19.88,21.51,23.06,24.55,25.96$

/ MILD CARBON STEEL

SPECIFICHEAT (SET = "MCSTEEL" , CURVE=14, TEMPERATURE, SPATIAL)

$-1.0 \mathrm{E}+6,294.27,310.94,366.49,422.05,477.60,533.16$,

$588.72,644.27,699.83,810.94,922.05,1033.16,1144.27$,

$437.53,437.53,450.22,486.46,515.21,538.84,559.73$, 
$580.25,602.79,629.70,706.20,828.74,1758.5,705.89$ DENSITY (SET= "MCSTEEL" , CONSTANT=7852.2506)

CONDUCTIVITY (SET= "MCSTEEL", CURVE=14, TEMPERATURE, ISOTROPIC)

$-1.0 \mathrm{E}+6,294.27,310.94,366.49,422.05,477.60,533.16$,

$588.72,644.27,699.83,810.94,922.05,1033.16,1144.27$,

$51.733,51.733,51.510,50.574,49.368,47.930,46.298$,

$44.508,42.599,40.607,36.525,32.562,29.016,26.187$

/ CONCRETE

SPECIFICHEAT (SET= "CONCRETE" , CURVE=5 , TEMPERATURE, SPATIAL)

$1.0,273.16,473.16,773.16,1273.16$,

$627.04,607.04,919.66,1.045 .07,1254.09$

DENSITY (SET = "CONCRETE" , CONSTANT" $=2300.08$ )

CONDUCTIVITY (SET="CONCRETE" , CONSTANT=0.753634473)

/ DRY HANFORD SOIL - EARTH

SPECIF ICHEAT (SET = "DRYEARTH" , CONSTANT=795.45)

DENSITY (SET = " DRYEARTH " CONSTANT $=1799.37)$

CONDUCTIVITY (SET = "DRYEARTH" , CONSTANT=0.334942)

1 LEAD

SPECIFICHEAT (SET = " LEAD", CURVE=13, TEMPERATURE, SPATIAL)

$100.00,293.16,373.16,389.16,472.16,533.16,573.16,578.16,600.66$, $600.76,605.16,654.16,964.16$

$127.7,125.6,125.6,125.6,125.6,138.6,125.6,140.7,141.5,142.3$,

$142.3,141.8,139.8$

DENSITY (SET $=$ "LEAD", CONSTANT $=11350.0)$

CONDUCTIVITY (SET = "LEAD", CURVE=13, TEMPERATURE, ISOTROPIC)

$100.00,293.16 .373 .16,389.16,472.16,533.16,573.16,578.16,600.66$,

$600.76,605.16,654.16,964.16$,

$35.58,35.14,33.42,34.02,31.03,29.30,29.76,25.11,21.65,21.64,20.93$,

$16.74,14.98$

/ POIYETHYLENE - MEDIUM DENSITY

SPECIEICHEAT (SET="PE" , CONSTANT=2302 . 619)

DENSITY (SET $=$ "PE" , CONSTANT=935.0)

CONDUCTIVITY (SET = "PE" , CONSTANT =0.41449)

$/$ SMEAR_AIR $=$ AIR + ZIRC4 + UO2 FOR SHIPPINGPORT BFA

CONDUCTIVITY (SET = "SMEAR_AIR", CURVE=18, TEMPERATURE, ISOTROPIC)

$100.0,200.0,300.0,350.0,400.0,450.0,500.0,550.0,600.0,650.0,700.0$,

$750.0,800.0,850.0,900.0,950.0,1000.0,10000.0$,

$6.11923,6.11923,6.11923,5.92803,5.97138,6.01048,6.02489,6.04687$,

$6.11063,6.19266,6.28486,6.38110,6.48980,6.61174,6.74800,6.90329$,

7. $04965,7.04965$

$/$ SMEAR HE $=H E+Z I R C 4+$ UO2 FOR SHIPPINGPORT BFA

CONDUCTIVITY (SET="SMEAR_HE", CURVE=18, TEMPERATURE, ISOTROPIC)

$100.0,200.0,300.0,350.0,400.0,450.0,500.0,550.0,600.0,650.0,700.0$, $750.0,800.0,850.0,900.0,950.0,1000.0,10000.0$,

$6.16860,6.16860,6.16860,5.98167,6.02936,6.07343,6.09287,6.12065$,

$6.19029,6.27732,6.37457,6.47547,6.58886,6.71538,6.85621,7.01608$,

$7.16711,7.16711$

/

$/$ EMISSIVITIES - 1 = STORAGE TUBE - MILD CARBON STEEL

/

1

$/$

I

EMISSIVITY (SET $=1$, CONSTANT $=0.50, S T E F B=5.6697 \mathrm{E}-8$ )

EMISSIVITY (SET $=2$, CONSTANT $=0.01$, STEFB $=5.6697 \mathrm{E}-8$ )

EMISSIVITY (SET $=3$, CONSTANT $=0.25$, STEFB $=5.6697 \mathrm{E}-8$ )

EMISSIVITY (SET $=4, \operatorname{CONSTANT}=0.70, \operatorname{STEFB}=5.6697 \mathrm{E}-8)$

/

' INITIAL CONDITIONS - TEMPERATURES

I

ICNODE ( TEMPERATURE, READ, AIL)

/ICNODE (TEMPERATURE, CONSTANT=333.15, ALL)

I

/ BOUNDARY CONDITIONS

, TAMB $=$ REFTEMP $=140 \mathrm{~F}=60 \mathrm{C}=333.15 \mathrm{~K}$

$2=$ RADIATION SYMMETRY (X AND Y AXIS)

$3=\mathrm{MCO}$ AND CROSS - BRIGHT $S S 316$

$4=$ OXIDIZED ZIRCAIOY -4
HNF-4109, Rev. 0

Appendix A

l 
RADSURFACE (ENTITY = "STID_RAD", INDIVIDUAL)

RADSURFACE (ENTITY = "MCOSTRHS_RAD" , INDIVIDUAL)

RADSURFACE (ENTITY= "MCOSTLHS_RAD" , INDIVIDUAL)

RADSURFACE (ENTITY = "MCOOD_RAD" , INDIVIDUAL)

RADSURFACE (ENTITY= "MCOID_RAD1 " , INDIVIDUAL)

RADSURFACE (ENTITY= "MCOID_RAD2", INDIVIDUAL)

RADSURFACE (ENTITY = "VCROSS_RAD1" , INDIVIDUAL)

RADSURFACE (ENTITY= "VCROSS_RAD2" , INDIVIDUAL)

RADSURFACE (ENTITY="VCROSS_RAD3 " , INDIVIDUAL)

RADSURFACE (ENTITY = "VCROSS_RAD4" , INDIVIDUAL)

RADSURFACE (ENTITY="VCROSS_RAD5", INDIVIDUAL)

RADSURFACE (ENTITY = "VCROSS_RAD6" , INDIVIDUAL)

RADSURFACE (ENTITY= "HCROSS_RADI", INDIVIDUAL)

RADSURFACE (ENTITY = "HCROSS_RAD2" , INDIVIDUAL)

RADSURFACE (ENTITY = "HCROSS_RAD3", INDIVIDUAL)

RADSURFACE (ENTITY= "HCROSS_RAD4 " , INDIVIDUAL)

RADSURFACE (ENTITY= "CAN1OD_RAD1" , INDIVIDUAL)

RADSURFACE (ENTITY= "CAN1OD_RAD2" , INDIVIDUAL)

RADSURFACE (ENTITY = "CAN1OD_RAD3" , INDIVIDUAI)

RADSURFACE (ENTITY = "CAN1OD_RAD4" , INDIVIDUAL)

RADSURFACE (ENTITY = "CAN2OD_RADI" , INDIVIDUAL)

RADSURFACE (ENTITY= "CAN2OD_RAD2" , INDIVIDUAL)

RADSURFACE (ENTITY="CAN2OD_RAD3", INDIVIDUAL)

RADSURFACE (ENTITY = "CAN2OD_RAD4", INDIVIDUAL)

OBSTRUCTION (ALL)

VIEWFACTOR (NOCOMPUTE, FACET, OUTPUTFILE, BINARY, SMOOTH , XZONE=12, YZONE=12)

$/$

/ HEAT TRANSFER COEFFICIENTS ( $/$ /M2-S-K)

I

HTRANSFER (SET="AIR1 $10 "$, CURVE=34, TEMPERATURE , REFPEMP=316.48)

$273.0,283.0,293.0,300.0,310.0,315.0,317.5,320.0,325.0,330.0$, $332.0,335.0,340.0,350.0,360.0,370.0,380.0,390.0,400.0,410.0$, $420.0,430.0,440.0,450.0,475.0,500.0,550.0,600.0,650.0,700.0$, $800.0,900.0,1000.0,100000.0$,

$4.469,4.042,3.542,3.117,2.256,1.372,1.209,1.823,2.435,2.826$, $2.953,3.123,3.365,3.747,4.044,4.285,4.485,4.655,4.800,4.924$, $5.038,5.150,5.251,5.341,5.526,5.662,5.868,6.022,6.110,6.194$, $6.286,6.327,6.328,6.400$

HTRANSFER (SET="AIR140", CURVE=34, TEMPERATURE, REFTEMP=333.15)

$273.0,283.0,293.0,300.0,310.0,315.0,317.5,320.0,325.0,330.0$, $332,0,335.0,340.0,350.0,360.0,370.0,380.0,390.0,400.0,410.0$, $420.0,430.0,440.0,450.0,475.0,500.0,550.0,600.0,650.0,700.0$, $800.0,900.0,1000.0,100000.0$,

$4.869,4.513,4.145,3.862,3.393,3.113,2.955,2.781,2.359,1.709$, $1.219,1.424,2.191,2.926,3.379,3.712,3.974,4.188,4.367,4.535$, $4.683,4.813,4.929,5.031,5.240,5.393,5.654,5.821,5.943,6.032$, $6.154,6.211,6.228,6.300$

/

RENUMBER

END

CREATE (FISOLV)

END( ) 
Document Reviewed:

HNF-4109, Rev. 0 "Therma1 Assessment of Shippingport Pressurized Water Reactor Blanket Fuel Assemblies within a Multi-Canister Overpack within the Canister Storage Building"

Scope of Review:

Yes No NA

$\bigcirc \otimes *$ Previous reviews complete and cover analysis, up to scope of this review, with no gaps.

(1) $\bigcirc \bigcirc$ Problem completely defined.

$\bigcirc \otimes$ Accident scenarios developed in a clear and logical manner.

(8) $\bigcirc \bigcirc$ Necessary assumptions explicitly stated and supported.

(1) $\bigcirc$ Computer codes and data files documented.

Q 00

$\otimes 00$

Data used in calculations explicitly stated in document.

Q 00

Data checked for consistency with original source information as applicable.

Q 00

Mathematical derivation checked including dimensional consistency of resuits.

Models appropriate and used within range of validity or use outside range of established validity justified.

$\otimes 00$

Hand calculations checked for errors. Spreadsheet results should be treated exactly the same as hand calculations.

(4) 0

Software input correct and consistent with document reviewed.

$\otimes 00$

Software output consistent with input and with results reported in document reviewed.

$\bigcirc \bigcirc \otimes$

Limits/criteria/guidelines applied to analysis results are appropriate and referenced.

Limits/criteria/guidelines checked against references.

(8) 0

Safety margins consistent with good engineering practices.

$\otimes 00$

Conclusions consistent with analytical results and applicable limits.

$\otimes 00$

Results and conclusions address all points required in the problem statement.

Q 00

Format consistent with appropriate NRC Regulatory Guide or other standards.

$00 \otimes$

* Review calculations, comments, and/or notes are attached.

$\bigcirc \bigcirc \quad$ Document approved.

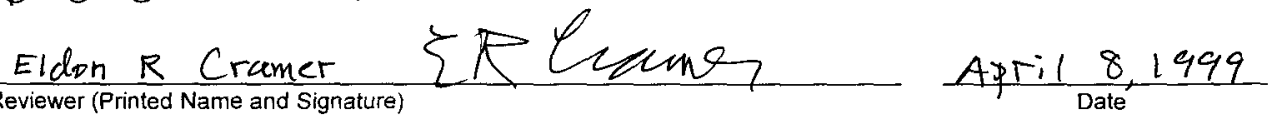

*Any calculations, comments, or notes generated as part of this review should be signed, dated and attached to this checklist. Such material should be labeled and recorded in such a manner as to be intelligible to a technically qualified third party. 


\section{DISTRIBUTION SHEET}

To

Distribtution

Project TitleMork Onder
From

NHC
Page 1 of 1

Date April 8, 199

EDT No. 626227

ECN No.

\section{Name}

G. D. Bazinet

A. B. Carlson

T. A. Flament

L. J. Garvin

F. J. Heard (5)

D. M. Johnson

R. I. McCormack

J. P. Sloughter

Central Files

DOE Reading Room

SNF Project File

DIMC

\begin{tabular}{|c|c|c|c|c|}
\hline MSI & $\begin{array}{c}\text { Text } \\
\text { With All } \\
\text { Attach. }\end{array}$ & Text Only & $\begin{array}{c}\text { Attach./ } \\
\text { Appendix } \\
\text { Only }\end{array}$ & $\begin{array}{c}\text { EDT/ECN } \\
\text { Only }\end{array}$ \\
\hline
\end{tabular}

S8-06

R3-73

R3-26

HO-34

R3-11

R3-11

H0-34

B1-07

H6-15

R3-11

H6-15
H0-34

\section{$\mathrm{x}$}

$\mathrm{x}$

$\mathrm{x}$

$\mathrm{X}$

$\mathrm{X}$

$\mathrm{x}$

$\mathrm{x}$

$\mathrm{X}$

$\mathrm{x}$

$\mathrm{X}$

$\mathrm{x}$

$\mathrm{x}$

$\mathrm{x}$

